\title{
Colombia: Statistical Appendix
}

This Statistical Appendix report on Colombia was prepared by a staff team of the International Monetary Fund as background documentation for the periodic consultation with this member country. As such, the views expressed in this document are those of the staff team and do not necessarily reflect the views of the Government of Colombia or the Executive Board of the IMF.

Copies of this report are available to the public from

International Monetary Fund $\bullet$ Publication Services 700 19th Street, N.W. • Washington, D.C. 20431

Telephone: (202) 623-7430 • Telefax: (202) 623-7201

Telex (RCA): 248331 IMF UR

E-mail: publications@imf.org

Internet: http://www.imf.org

Price: $\$ 15.00$ a copy

\section{International Monetary Fund Washington, D.C.}




\title{
INTERNATIONAL MONETARY FUND
}

\section{COLOMBIA}

\author{
Statistical Appendix \\ Prepared by a staff team consisting of Olav Gronlie (Head), Marco Terrones, \\ Jose Gil-Diaz, Keiko Honjo (all WHD), and Marco Rossi (PDR) \\ Approved by the Western Hemisphere Department
}

December 10, 1999

Contents

Page

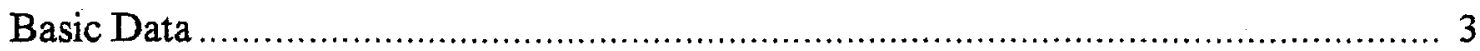

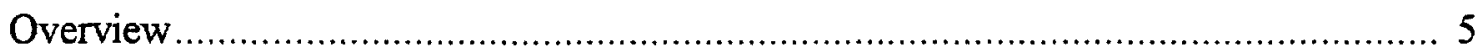

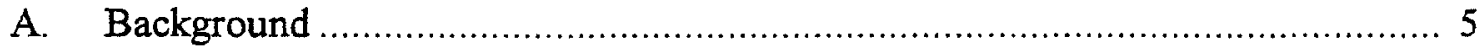

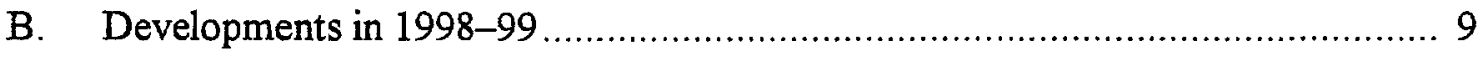

Text Tables

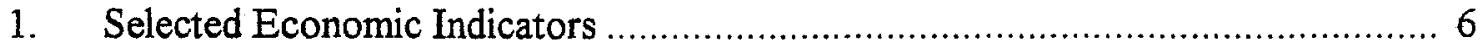

2. Operations of the Combined Public Sector .................................................. 7

3. Summary Balance of Payments.............................................................. 8

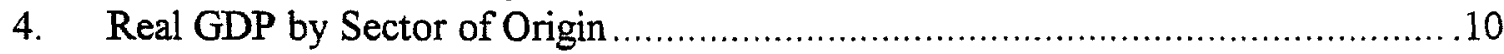

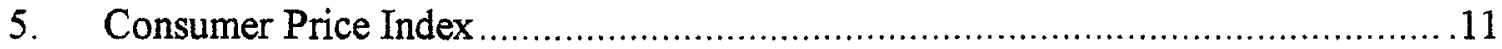

6. Summary Accounts of the Financial System ....................................... 13

Statistical Appendix Tables

1. National Accounts at Current Prices................................................... 16

2. National Accounts at Constant Prices........................................................... 17

3. Aggregate Supply and Demand at Constant Prices .................................. 18

4. Saving and Investment ....................................................................... 19

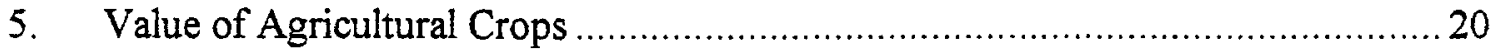

6. Coffee Stocks, Production, Exports, and Prices....................................... 21

7. Coffee Output and Exports by Calendar and Coffee Years................................. 22

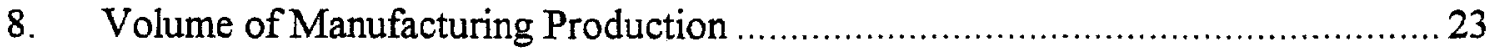

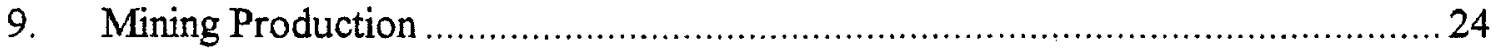

10. National Production and Consumption of Petroleum Products..........................25

11. Structure of Regular Gasoline Prices ....................................................... 26

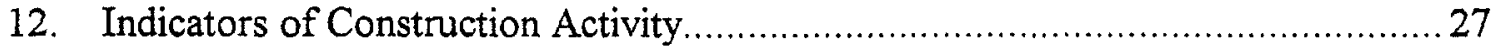

13. Quarterly Survey of Unemployment and Participation Rates ............................ 28

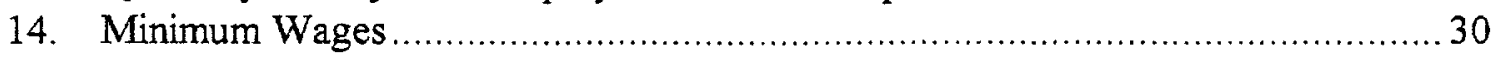




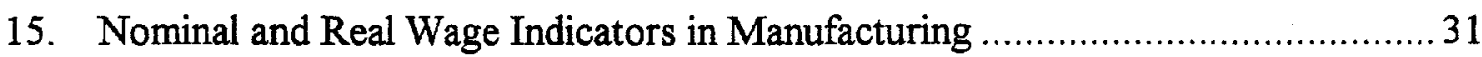

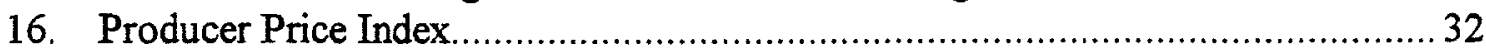

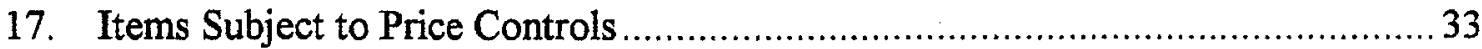

18. Operations of the Combined Public Sector ......................................................... 34

19. Operations of the Central Administration (In billions of Colombian pesos) ...........35

20. Operations of the Central Administration (In percent of GDP).........................36

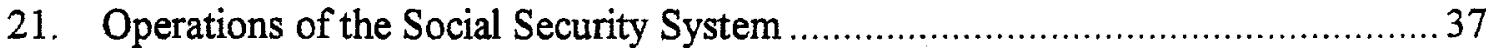

22. Operations of the National Decentralized Agencies .........................................38

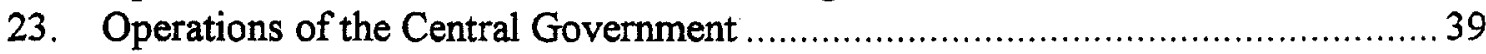

24. Operations of the Local Nonfinancial Public Sector ...........................................4

25. Operations of the General Government ........................................................ 41

26. Operations of the Consolidated National Enterprises

(In billions of Colombian pesos) ...........................................................42

27. Operations of the Consolidated National Enterprises (In percent of GDP) ..........43

28. Operations of Selected Nonfinancial Public Enterprises ...................................... 44

29. Summary Accounts of the Banco de la Republica (In billions of

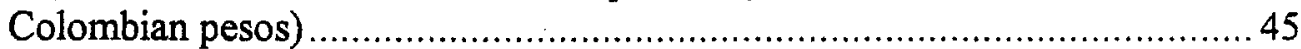

30. Summary Accounts of the Commercial Banks ................................................4

31. Summary Accounts of the Specialized Financial Institutions ...............................47

32. Summary Accounts of the Financial System (In billions of Colombian pesos).......48

33. Summary Accounts of the Banco de la Republica (Percentage change) ................49

34. Summary Accounts of the Financial System (Percentage change) …...................50

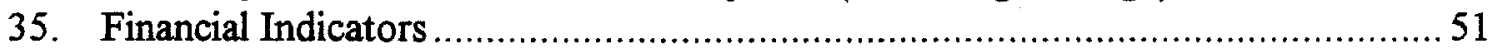

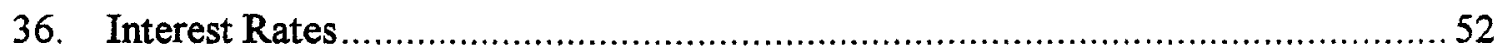

37. Requirements for Monetary Reserves, Reserve-Substituting Investments, and Obligatory Investments ............................................5 53

38. Reserves, Open Market Instruments, and Exchange Certificates .......................5 54

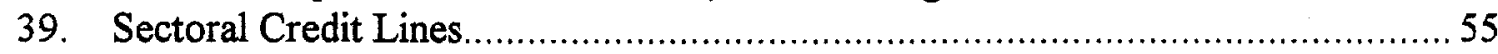

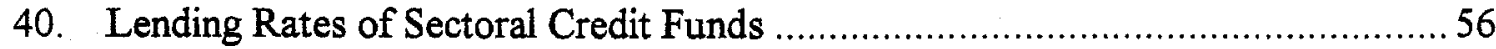

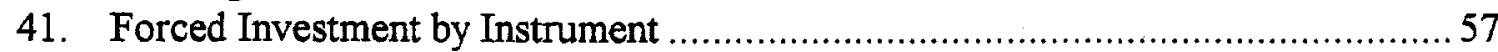

42. Net International Reserves of the Banco de la Republica ....................................58

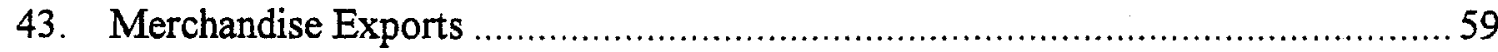

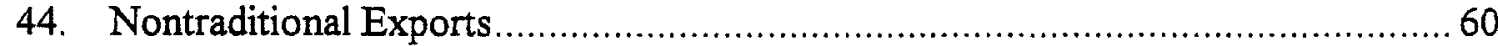

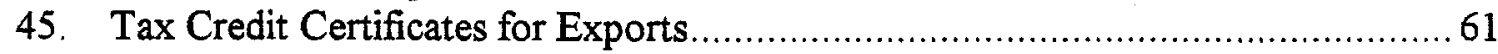

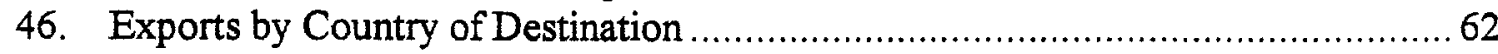

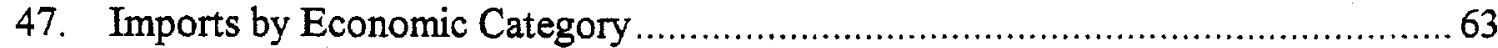

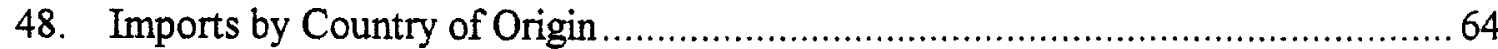

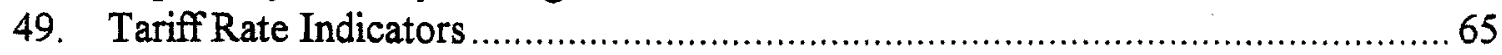

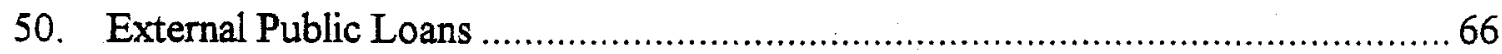

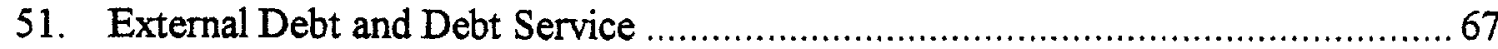

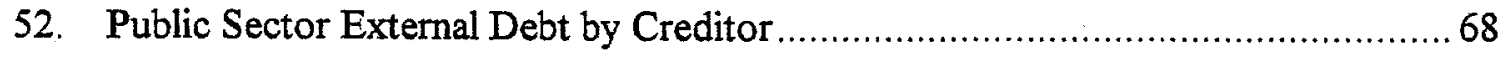




\section{Colombia: Basic Data}

\section{Social and Demographic Indicators}

(latest available, 1992-1998 otherwise indicated)

Area (thousand sq. km)
Population (1998)
Total (million)
Rate of increase (percent a year)
Density (per sq. km.)
GDP per capita (US\$)
Unemployment (September 1999)
Population characteristics
Life expectancy at birth (years)
Crude birth rate (per thousand)
Crude death rate (per thousand)
Infant mortality (per thousand live births)
Income distribution (1995)
By highest 20 percent of households
By lowest 20 percent of households

\begin{tabular}{|c|c|}
\hline 38,914 & $\begin{array}{l}\text { Nutrition (1988-90) } \\
\text { Calorie intake } \\
\text { (percent of requirements) }\end{array}$ \\
\hline $\begin{array}{r}40.9 \\
1.7 \\
32.8 \\
2,443 \\
20.1\end{array}$ & $\begin{array}{l}\text { Health (1994) } \\
\text { Population per physician }\end{array}$ \\
\hline $\begin{array}{r}70.0 \\
22.8 \\
4.9 \\
24.0\end{array}$ & $\begin{array}{l}\text { Access to safe water (percent } \\
\text { of population) } \\
\text { Total }\end{array}$ \\
\hline $\begin{array}{r}60 \\
2\end{array}$ & $\begin{array}{l}\text { Education (in percent) } \\
\text { Primary school } \\
\text { enrollment rate }\end{array}$ \\
\hline
\end{tabular}

II. Economic Indicators, 1994-1998

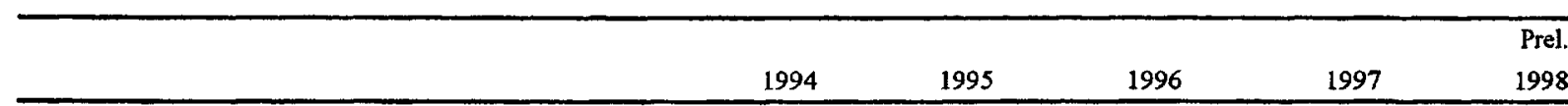

(In annual percent changes)

\section{National accounts and prices}

GDP at constant prices

Agriculture and mining

Manufacturing and construction

Other

Consumer price index (end of period)

Gross investment

Private consumption

Public consumption

Gross national saving

Public sector finances

Revenue

Non-interest expenditure

Primary balance (deficit -)

Overall balance (deficit -) 1/2/

Memorandum Items:

Primary balance (percent of GDP)

Nonfinancial public sector balance (percent of GDP)

Overall balance (percent of GDP) 1/2i

Monetary accounts 3 /

Money (MI)

Quasi-money

Net domestic assets

Credit to the public sector

Credit to the private sector

$\begin{array}{crrrr}5.8 & 5.2 & 2.1 & 3.2 & 0.4 \\ \ldots & 5.8 & 0.5 & 1.5 & 1.7 \\ \ldots & 4.6 & -5.4 & 1.0 & -3.6 \\ \ldots & 5.3 & 5.4 & 4.5 & 1.4 \\ 22.6 & 19.5 & 21.6 & 17.7 & 16.7 \\ & & & & \\ 25.5 & & & & \\ 65.9 & 65.8 & 22.2 & 21.0 & 19.6 \\ 14.5 & 14.9 & 65.5 & 66.8 & 68.1 \\ 21.1 & 20.8 & 18.0 & 18.5 & 18.9 \\ & & 17.3 & 15.5 & 13.7\end{array}$

(In billions of pesos)

$\begin{array}{rrrrr}16,541 & 21,439 & 27,154 & 33,376 & 37,733 \\ 14,962 & 20,211 & 26,783 & 34,765 & 38,557 \\ 1,578 & 1,228 & 371 & -1,389 & -824 \\ -116 & -491 & -2,358 & -4,605 & -4,403 \\ & & & & \\ 2.3 & 1.5 & 0.4 & -1.1 & -0.6 \\ 0.1 & -0.8 & -2.4 & -3.7 & -3.9 \\ -0.2 & -0.6 & -2.3 & -3.8 & -3.1 \\ & & & & \\ & & & & \\ 5,323 & 6,313 & 7,312 & 8,818 & 8,973 \\ 15,441 & 19,846 & 24,030 & 30,180 & 35,236 \\ 18,012 & 23,001 & 30,971 & 37,645 & 41,822 \\ 845 & 1,166 & 1,187 & 1,795 & 5,475 \\ 21,511 & 29,222 & 36,741 & 46,162 & 51,662\end{array}$


Colombia: Basic Data

II. Economic Indicators, 1994-1998

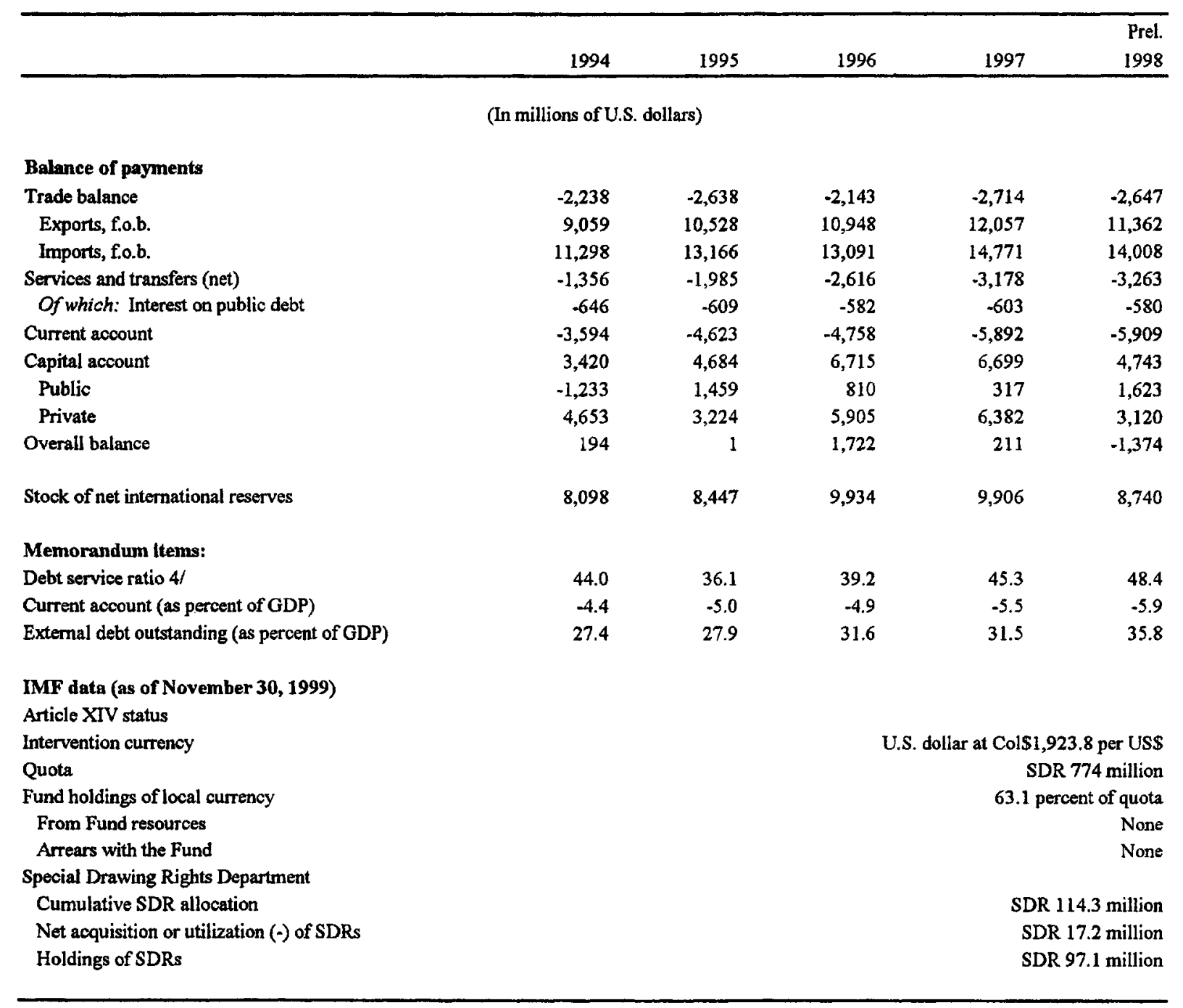

Sources: Colombian authorities; and Fund staff estimates.

1/ Includes quasi-fiscal transactions of the Banco de la Republica.

2/ Excludes asset sales and most proceeds from telephone concessions. Includes floating debt of the central administration.

$3 /$ End of period stocks.

4/ External debt service as percent of exports of goods and services. 


\section{OVERVIEW}

1. Economic performance deteriorated in 1998 and the recession has deepened further to date in 1999. The weak economic activity helped to lower the inflation and to narrow the external current account deficit. At the same time, the fiscal position and the health of the financial sector continued to deteriorate. In response, the authorities announced a mediumterm economic reform program in end-September 1999 that called for an immediate floating of the exchange rate, strong fiscal adjustment, financial sector restructuring, and an accelerated structural reform program. The authorities have requested Fund support for their program.

\section{A. Background}

2. Over the last two decades, the Colombian economy has recorded a robust economic performance, growing at $4 \frac{1}{2}$ percent a year on average, albeit with an inflation in the 20-30 percent range. In 1990-94 the country embarked on an ambitious structural reform program that included liberalization of the financial system and external trade, fiscal decentralization, social security and labor market reforms, and steps to promote foreign direct investment. During 1994-98, the government sought to consolidate these reforms, increase public spending on health, education and infrastructure, and tackle the persistent inflation (Table 1). However, under the weight of the new spending programs, the fiscal position deteriorated markedly. Fiscal management also became complicated by the widespread earmarking of public revenues and a constitutionally mandated revenue sharing arrangement. Under this arrangement, the central government continued to bear much of its original spending responsibilities, while a significant and rising proportion of its resources was transferred to territorial governments. As a result, the financial position of the nonfinancial public sector (NFPS) deteriorated from near balance in 1994 to a deficit of 3.7 percent of GDP in 1997 (Table 2).

\section{Following the liberalization of the trade and capital accounts, Colombia's} external current account position deteriorated from surpluses in the early 1990s to a deficit of $5 \frac{1}{2}$ percent in 1997 (Table 3). During this period, increased capital inflows complicated the management of the monetary policy. To limit the growth of liquidity resulting from the buildup of foreign reserves, the central bank introduced large sterilization operations, but the capital inflows continued as interest rate differentials widened in favor of Colombian assets. To stem these inflows, the authorities introduced capital controls in 1993 in the form of a nonremunerated deposit requirement on most foreign borrowing. In addition, to allow for greater flexibility in the operation of monetary policy, a "crawling band" exchange rate arrangement was adopted in 1994. Notwithstanding these measures, large capital inflows continued in the face of greater investor confidence associated with large new oil discoveries and privatization of some major public sector enterprises. From 1990 to 1997 the peso appreciated in real terms by more than 40 percent. Capital inflows began to decline in the 
Table 1. Colombia: Selected Economic Indicators

(Annual percentage change)

\begin{tabular}{|c|c|c|c|c|c|c|}
\hline & \multirow[b]{2}{*}{1995} & \multirow[b]{2}{*}{1996} & \multirow[b]{2}{*}{1997} & \multirow{2}{*}{$\begin{array}{l}\text { Prel. } \\
1998\end{array}$} & \multicolumn{2}{|c|}{$\begin{array}{c}\text { Prel. } \\
\text { Jan.-Jun. }\end{array}$} \\
\hline & & & & & 1998 & 1999 \\
\hline \multicolumn{7}{|l|}{ Output and income } \\
\hline Real GDP 1/ & 5.2 & 2.1 & 3.2 & 0.4 & 3.5 & -6.7 \\
\hline Nominal GDP & 25.0 & 19.3 & 20.8 & 17.2 & 21.5 & 5.2 \\
\hline Real domestic demand & 5.8 & 1.1 & 3.8 & -1.4 & 3.7 & -7.0 \\
\hline \multicolumn{7}{|l|}{ Prices } \\
\hline GDP deflator & 18.9 & 16.9 & 17.0 & 16.7 & 17.4 & 12.7 \\
\hline Domestic demand deflator & 18.7 & 17.2 & 17.1 & 19.2 & 16.5 & 9.7 \\
\hline Terms of trade (deterioration -) & 5.1 & 9.2 & 11.4 & -7.0 & -1.7 & -8.0 \\
\hline \multicolumn{7}{|l|}{ Consumer price index $2 /$} \\
\hline (end-of-period) & 19.5 & 21.6 & 17.7 & 16.7 & 20.7 & 9.0 \\
\hline (period average) & 20.9 & 20.8 & 18.5 & 18.7 & 19.5 & 12.7 \\
\hline Core inflation $2 / 3 /$ & 21.5 & 22.4 & 17.1 & 15.5 & 15.3 & 10.9 \\
\hline \multicolumn{7}{|l|}{ Wholesale prices $2 /$} \\
\hline (end-of-period) & 15.4 & 14.5 & 17.5 & 13.5 & 14.6 & 11.4 \\
\hline (period average) & 18.1 & 15.0 & 15.4 & 17.3 & 18.2 & 9.3 \\
\hline \multicolumn{7}{|l|}{ Real effective exchange rate 4 / } \\
\hline (end-of-period, depreciation -) & -3.5 & 21.0 & -3.2 & -4.5 & 5.9 & -15.4 \\
\hline
\end{tabular}

Sources: Colombian authorities; and Fund staff estimates.

1/ Data in last two columns refer to the first two quarters of corresponding year.

2/ Data in last two columns refer to October figures of corresponding year.

3/ Excludes agricultural foodstuffs, public services, and transport.

4/ Based on the Information Notice System. Data in last two columns refer to year through August of corresponding year. 
Table 2. Colombia: Operations of the Combined Public Sector

(In percent of GDP)

\begin{tabular}{|c|c|c|c|c|c|c|c|}
\hline & & & & & Prel. & Jan.- & In. $1 /$ \\
\hline & 1994 & 1995 & 1996 & 1997 & 1998 & 1998 & 1999 \\
\hline Total revenue & 24.5 & 25.4 & 27.0 & 27.4 & 26.5 & 25.5 & 26.0 \\
\hline Current revenue & 24.5 & 25.4 & 27.0 & 27.4 & 26.5 & 25.5 & 26.0 \\
\hline Tax revenue $2 /$ & 15.2 & 16.1 & 16.8 & 17.7 & 17.3 & 17.0 & 16.1 \\
\hline Nontax revenue & 9.1 & 9.3 & 10.1 & 9.8 & 9.1 & 8.5 & 9.9 \\
\hline Operating surplus of public enterprises & 4.6 & 4.3 & 4.7 & 3.7 & 3.3 & 3.8 & 4.0 \\
\hline Other $3 /$ & 4.5 & 5.0 & 5.4 & 6.0 & 5.9 & 4.7 & 5.9 \\
\hline Transfers & 0.1 & 0.0 & 0.0 & 0.0 & 0.0 & 0.0 & 0.0 \\
\hline Capital revenue & 0.0 & 0.0 & 0.0 & 0.0 & 0.0 & 0.0 & 0.0 \\
\hline Total expenditure and net lending & 24.4 & 26.2 & 29.3 & 31.2 & 30.3 & 29.2 & 31.2 \\
\hline Current expenditure & 17.4 & 18.3 & 20.6 & 21.6 & 22.4 & 21.9 & 23.3 \\
\hline Wages and salaries & 6.0 & 5.9 & 6.6 & 6.7 & 7.0 & 6.4 & 7.0 \\
\hline Goods and services & 3.1 & 3.1 & 3.5 & 3.7 & 3.4 & 3.5 & 3.2 \\
\hline Interest & 2.2 & 2.3 & 2.7 & 2.6 & 3.3 & 3.5 & 4.0 \\
\hline External & 1.2 & 1.1 & 1.0 & 1.0 & 1.1 & 1.0 & 1.3 \\
\hline Domestic & 1.0 & 1.2 & 1.7 & 1.6 & 2.2 & 2.5 & 2.7 \\
\hline Transfers & 5.9 & 6.7 & 7.7 & 7.9 & 8.4 & 8.1 & 8.9 \\
\hline Other 4/ & 0.2 & 0.3 & 0.2 & 0.8 & 0.2 & 0.4 & 0.3 \\
\hline Capital expenditure & 7.0 & 8.0 & 8.6 & 9.6 & 7.9 & 7.3 & 8.0 \\
\hline $\begin{array}{l}\text { Fixed capital formation } \\
\text { Of which }\end{array}$ & 6.6 & 7.9 & 8.4 & 9.1 & 7.8 & 7.1 & 7.9 \\
\hline On a cash basis & 6.6 & 7.4 & 8.0 & 9.2 & 7.7 & 7.0 & 7.5 \\
\hline Transfers & 0.3 & 0.1 & 0.2 & 0.4 & 0.1 & 0.2 & 0.1 \\
\hline Net lending $2 /$ & 0.0 & 0.0 & 0.0 & 0.0 & 0.0 & 0.1 & -0.1 \\
\hline Nonfinancial public sector balance & 0.1 & -0.8 & -2.4 & -3.7 & -3.9 & -3.7 & -5.2 \\
\hline Quasi-fiscal balance of the central bank & -0.3 & 0.3 & 0.0 & -0.1 & 0.8 & 0.6 & 0.4 \\
\hline Net cost of financial restructuring $5 /$ & -- & - & - & -- & - & - & 0.1 \\
\hline FOGAFIN balance & $\cdots$ & $\ldots$ & $\ldots$ & $\cdots$ & $\cdots$ & - & 0.3 \\
\hline Net budgetary cost of financial restructuring & $\ldots$ & $\ldots$ & $\ldots$ & $\ldots$ & $\ldots$ & $\because$ & -0.2 \\
\hline Overall balance & -0.2 & -0.6 & -2.3 & -3.8 & -3.1 & -3.1 & -4.7 \\
\hline Statistical discrepancy 6/ & 0.1 & -1.3 & -0.2 & 0.1 & 0.1 & 0.1 & 0.0 \\
\hline Financing & 0.1 & 1.8 & 2.5 & 3.7 & 3.0 & 3.0 & 4.7 \\
\hline Foreign & -2.0 & 1.2 & 0.9 & 0.6 & 1.9 & 1.2 & 1.4 \\
\hline Disbursements & 2.2 & 1.5 & 2.8 & 2.8 & 3.6 & 4.6 & 4.0 \\
\hline Amortization & -2.6 & -1.6 & -1.5 & -1.6 & -1.7 & -1.8 & -1.9 \\
\hline Short term & -1.6 & 1.2 & -0.4 & -0.6 & 0.0 & -1.6 & -0.7 \\
\hline Of which & & & & & & & \\
\hline Change in government reserves (increase -) & -1.4 & 1.0 & -0.4 & -0.6 & 0.1 & -1.4 & -0.1 \\
\hline Domestic & 0.0 & 0.6 & 0.8 & 1.8 & 1.0 & 1.8 & 3.2 \\
\hline Banco de la Republica & 0.1 & 0.2 & 0.1 & -0.1 & -0.4 & -0.2 & 1.1 \\
\hline Rest of financial system & $-0 . \dot{2}$ & -0.5 & 0.0 & 0.6 & 0.9 & 1.4 & 0.0 \\
\hline Bonds & -0.1 & 0.1 & 0.2 & 1.4 & 0.2 & 0.2 & 1.4 \\
\hline Change in floating debt & 0.2 & 0.8 & 0.6 & -0.2 & 0.3 & 0.5 & 0.7 \\
\hline Privatization proceeds $7 /$ & 2.1 & 0.1 & 0.8 & 1.3 & 0.1 & 0.0 & 0.0 \\
\hline Memorandum items: & & & & & & & \\
\hline Security expenditure 8/ & 2.5 & 2.5 & 2.8 & 3.3 & 3.2 & 3.2 & 3.3 \\
\hline Public sector savings & 6.8 & 7.4 & 6.3 & 5.8 & 4.8 & 4.2 & 3.4 \\
\hline Overall primary balance & 2.3 & 1.5 & 0.4 & -1.1 & -0.6 & -0.2 & -1.2 \\
\hline
\end{tabular}

Sources: Ministry of Finance and Public Credit; and Banco de la Republica.

$1 /$ In percent of estimated GDP of the period.

2/ Excludes proceeds of financial transaction tax in 1999 from revenue and expenditure.

$3 /$ Includes local fees, penalties and oil stabilization fund.

4/ Includes expenditure on an accrual basis not included in other outlays.

5/ Transfer to Caja Agraria in 1999, interest payments on public banks restructuring bonds and mortgage debt relief related costs.

6/ Includes residual differences between items above and below the line

$7 /$ Includes nonrecurrent fees from telecommunications licensing.

8/ Includes army and police wages and purchases of goods and services. 
Table 3. Colombia: Summary Balance of Payments

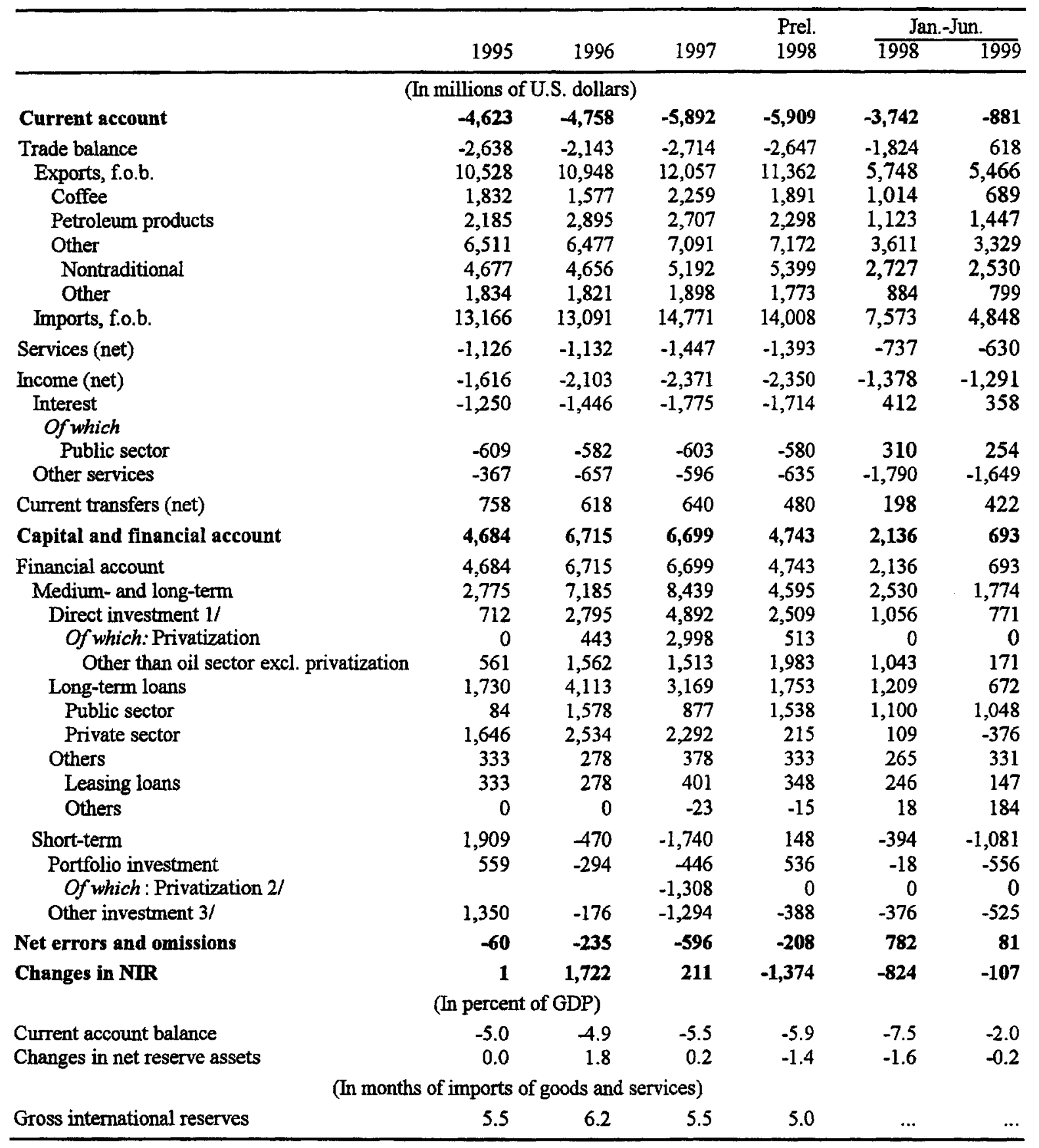

Sources: Banco de la Republica; and Fund staff estimates and projections.

$1 /$ Net of capital remittance of the oil sector. In 1999, this includes US\$ 475 million as a result of the decapitalization of EEB.

$2 /$ Consists of movements in deposits held abroad in response to privatization receipts.

$3 /$ Includes trade credits, short-term borrowing, and deposits held by the Colombian residents in current account abroad net of interest payments of deposits held by nonresidents in Colombia. 
second half of 1997 as domestic interest rates fell and the central bank eased restrictions on the prepayment of foreign loans.

\section{B. Developments in 1998-99}

4. Output growth slowed markedly during 1998. Economic activity continued to expand sharply through the first half of the year mainly in response to fiscal expansion, an accommodating monetary policy initiated in the second half of 1997, and higher oil production at the Cusiana oil field. However, the economic situation turned around beginning in the second half of 1998, as domestic demand weakened in the face of external shocks, turmoil in international financial markets, rising uncertainty associated with increased insurgent activity, and a tightening of macroeconomic policies. Real GDP growth for the year as a whole fell to 0.4 percent, from 3.2 percent the year before (Table 4 ).

5. As the recession deepened, unemployment rose to $\mathbf{1 5 . 7}$ percent by the end of 1998 from 12 percent a year earlier (Statistical Appendix Table 13). Inflation was subject to upward pressures in the first half of 1998 reflecting the impact of the El Niño weather phenomenon on food prices. It declined in the second half with the slowing of economic activity, ending the year at 16.7 percent, compared with an official inflation target of 16 percent (Table 5).

6. The fiscal position continued to deteriorate in 1998. Soon after taking office in August 1998, the Pastrana administration took steps to respond to the difficult fiscal outlook. These steps included spending cuts, a widening of the VAT base, increased fuel taxes, and the introduction of programs to strengthen tax enforcement. Notwithstanding these measures, the efforts to contain the widening fiscal deficit were constrained by the mandatory revenue sharing arrangements and the inflexibility of outlays on wages, interest payments, and national security. As a result, the NFPS deficit widened somewhat to 4 percent of GDP in 1998. The deficit was financed to a large extent by external bond issues before market access became difficult in the wake of the Russian crisis in August.

7. The external current account deficit widened to nearly 6 percent of GDP in 1998 from $51 / 2$ percent in 1997 . This was mainly attributable to strong import demand during the first half of the year, in part boosted by the strong economic activity and expectations of an exchange rate depreciation. Export revenue declined along the year owing to a drop in commodity prices (particularly for coffee and petroleum), which offset an increase in nontraditional exports. Colombia's capital account surplus narrowed sharply as private capital inflows dropped, and uncertainty about exchange rate developments prompted domestic residents to prepay foreign debts. Net international reserves (NIR) fell by nearly US $\$ 1.4$ billion, reflecting intervention to maintain the value of the peso within the band.

\section{Monetary policy in 1998 was primarily geared toward tightening liquidity} conditions in an effort to contain the pressures against the peso. Growing concerns about the sustainability of Colombia's large fiscal and external deficits resulted in repeated episodes of attacks on the currency from the last half of 1997. These pressures intensified in early 1998 
Table 4. Colombia: Real GDP by Sector of Origin

\begin{tabular}{|c|c|c|c|c|c|}
\hline & 1994 & 1995 & 1996 & $\begin{array}{l}\text { Prel. } \\
1997\end{array}$ & $\begin{array}{l}\text { Prel. } \\
1998\end{array}$ \\
\hline \multicolumn{6}{|c|}{ (In millions of 1994 Colombian pesos) } \\
\hline Total GDP & $67,532,862$ & $71,046,217$ & $72,506,824$ & $74,856,045$ & $75,185,412$ \\
\hline Agriculture & $10,016,162$ & $10,390,067$ & $10,261,722$ & $10,306,093$ & $10,330,739$ \\
\hline Mining & $2,332,644$ & $2,672,603$ & $2,867,403$ & $3,017,001$ & $3,213,148$ \\
\hline Manufacturing & $10,127,887$ & $10,726,462$ & $10,528,114$ & $10,836,516$ & $10,809,494$ \\
\hline Construction & $5,029,719$ & $5,125,093$ & $4,462,104$ & $4,302,732$ & $3,778,973$ \\
\hline Commerce & $8,336,559$ & $8,617,163$ & $8,589,476$ & $8,808,421$ & $8,790,382$ \\
\hline Transport & $4,920,053$ & $5,240,338$ & $5,441,143$ & $5,797,104$ & $6,007,799$ \\
\hline Public administration & $4,354,196$ & $4,793,367$ & $6,149,376$ & $6,632,102$ & $6,783,180$ \\
\hline Other & $22,415,642$ & $23,481,124$ & $24,207,486$ & $25,156,075$ & $25,471,698$ \\
\hline \multicolumn{6}{|c|}{ (Annual percentage change) } \\
\hline Total GDP & 5.8 & 5.2 & 2.1 & 3.2 & 0.4 \\
\hline Agriculture & 1.2 & 3.7 & -1.2 & 0.4 & 0.2 \\
\hline Mining & 2.0 & 14.6 & 7.3 & 5.2 & 6.5 \\
\hline Manufacturing & 1.6 & 5.9 & -1.8 & 2.9 & -0.2 \\
\hline Construction & 9.0 & 1.9 & -12.9 & -3.6 & -12.2 \\
\hline Commerce & 6.9 & 3.4 & -0.3 & 2.5 & -0.2 \\
\hline Transport & 5.8 & 6.5 & 3.8 & 6.5 & 3.6 \\
\hline Public administration & 4.8 & 10.1 & 28.3 & 7.9 & 2.3 \\
\hline Other & 12.7 & 4.8 & 3.1 & 3.9 & 1.3 \\
\hline \multicolumn{6}{|c|}{ (In percent of GDP) } \\
\hline Total GDP & 100.0 & 100.0 & 100.0 & 100.0 & 100.0 \\
\hline Agriculture & 14.8 & 14.6 & 14.2 & 13.8 & 13.7 \\
\hline Mining & 3.5 & 3.8 & 4.0 & 4.0 & 4.3 \\
\hline Manufacturing & 15.0 & 15.1 & 14.5 & 14.5 & 14.4 \\
\hline Construction & 7.4 & 7.2 & 6.2 & 5.7 & 5.0 \\
\hline Commerce & 12.3 & 12.1 & 11.8 & 11.8 & 11.7 \\
\hline Transport & 7.3 & 7.4 & 7.5 & 7.7 & 8.0 \\
\hline Public administration & 6.4 & 6.7 & 8.5 & 8.9 & 9.0 \\
\hline Other & 33.2 & 33.1 & 33.4 & 33.6 & 33.9 \\
\hline
\end{tabular}

Source: National Department of Statistics (DANE) - Colombian authorities. 
Table 5. Colombia: Consumer Price Index

\begin{tabular}{|c|c|c|c|c|c|c|}
\hline & \multirow[b]{2}{*}{ Total } & \multirow[b]{2}{*}{ Food } & \multicolumn{4}{|c|}{ Non-Food } \\
\hline & & & Total & Housing & Clothing & Other \\
\hline \multicolumn{7}{|c|}{ (Annual average percentage change) } \\
\hline 1994 & 22.8 & 20.9 & 23.8 & 26.1 & 15.0 & 22.4 \\
\hline 1995 & 20.9 & 19.2 & 21.7 & 23.5 & 12.8 & 19.9 \\
\hline 1996 & 20.8 & 16.3 & 22.9 & 23.1 & 11.9 & 23.4 \\
\hline 1997 & 18.5 & 15.9 & 19.6 & 19.8 & 9.8 & 20.1 \\
\hline 1998 & 18.7 & 22.3 & 17.2 & 16.4 & 8.5 & 19.7 \\
\hline \multicolumn{7}{|c|}{ (12-month percentage change) } \\
\hline \multicolumn{7}{|l|}{1994} \\
\hline March & 23.4 & 19.3 & 25.5 & 27.9 & 17.0 & 24.2 \\
\hline June & 23.1 & 21.4 & 23.9 & 26.1 & 15.1 & 22.5 \\
\hline September & 22.3 & 21.8 & 22.6 & 24.7 & 13.5 & 21.1 \\
\hline December & 22.6 & 23.0 & 22.4 & 24.7 & 12.9 & 20.5 \\
\hline \multicolumn{7}{|l|}{1995} \\
\hline March & 21.3 & 20.5 & 21.7 & 24.3 & 13.0 & 18.7 \\
\hline June & 21.7 & 20.7 & 22.1 & 24.6 & 12.9 & 19.7 \\
\hline September & 20.8 & 18.7 & 21.8 & 22.8 & 12.8 & 21.3 \\
\hline December & 19.5 & 16.2 & 21.0 & 21.6 & 12.6 & 21.0 \\
\hline \multicolumn{7}{|l|}{1996} \\
\hline March & 20.2 & 16.5 & 21.9 & 22.0 & 12.1 & 22.6 \\
\hline June & 19.7 & 12.8 & 22.9 & 22.2 & 11.8 & 24.6 \\
\hline September & 21.6 & 16.6 & 23.8 & 24.6 & 11.8 & 23.5 \\
\hline December & 21.6 & 18.3 & 23.2 & 24.0 & 11.0 & 22.8 \\
\hline \multicolumn{7}{|l|}{1997} \\
\hline March & 18.9 & 13.5 & 21.3 & 22.0 & 10.5 & 21.2 \\
\hline June & 18.7 & 16.4 & 19.7 & 20.7 & 9.9 & 19.2 \\
\hline September & 18.0 & 17.8 & 18.1 & 17.9 & 9.2 & 19.1 \\
\hline December & 17.7 & 16.4 & 18.2 & 17.6 & 9.4 & 20.3 \\
\hline \multicolumn{7}{|l|}{1998} \\
\hline March & 19.2 & 23.1 & 17.6 & 17.2 & 8.8 & 19.9 \\
\hline June & 20.7 & 30.0 & 16.8 & 15.9 & 8.5 & 19.2 \\
\hline September & 17.8 & 20.3 & 16.7 & 15.6 & 8.3 & 19.6 \\
\hline December & 16.7 & 15.7 & 17.1 & 16.6 & 7.8 & 19.4 \\
\hline \multicolumn{7}{|l|}{1999} \\
\hline March & 13.5 & 11.7 & 14.3 & 14.0 & 7.1 & 15.7 \\
\hline June & 9.0 & 0.3 & 13.0 & 11.4 & 5.3 & 16.0 \\
\hline September & 9.3 & 4.2 & 11.6 & 6.6 & 4.4 & 15.3 \\
\hline
\end{tabular}

Source: National Department of Statistics (DANE). 
in the wake of the turmoil in Asian markets and political uncertainty in the period leading up to the presidential elections. To contain the pressures, the central bank tightened the monetary policy in February 1998 by raising the central bank's intervention band for interbank interest rates by 3 percentage points to 23-30 percent and increasing the yield on open-market bills. To promote greater capital inflows, the deposit requirement on external borrowing was relaxed. ${ }^{1}$ Monetary policy was further tightened in May through the suspension of base money as the intermediate target for monetary policy and the elimination of the intervention band for interbank interest rates. This resulted in record high interest rates, with the 90 -days benchmark deposit rate rising to nearly 40 percent and the lending rate exceeding 50 percent. The exchange rate pressures eased somewhat through mid-August but resumed in late August as market sentiment towards emerging market countries deteriorated following the developments in Russia. In response, the central bank intervened to defend the peso, but depreciated the intervention band by 9 percentage points in early September.

9. The decline in net international reserves and the decision of the central bank in early 1998 to shift its intermediate target for monetary policy to exchange rate stabilization resulted in a sharp decline in the growth of the monetary aggregates. Base money and broad money growth declined to -16.6 percent and 10.3 percent, respectively, in 1998 from 25 percent and 24.5 percent a year earlier. Credit growth to the private sector dropped to 11.9 percent in December 1998 from 25.6 percent in 1997 while net domestic credit to the NFPS rose sharply as the government did not access the international financial markets in the second half of the year (Table 6).

10. The health of the financial sector deteriorated markedly in 1998 owing to the sharp rise in interest rates and the weakening macroeconomic environment. By November, the nonperforming loan ratio (as a share of total loans) had risen to nearly 11 percent, from 6.7 percent in December 1997. Against this background, an economic emergency was declared in November under which programs were introduced to provide debt relief to mortgage holders financed by a new tax on financial transactions.

11. The recession intensified in the first half of 1999, with real GDP contracting by 6.7 percent year-on-year. Unemployment rose to 20.1 percent in September while 12-month inflation has been in single digits since mid-1999. Preliminary indicators point to some recovery in economic activity in the third quarter, notably in the export sector, helped by the 15 percent real depreciation of the peso during 1999 to August. Agriculture is recovering from the effects of the El Niño weather phenomenon in 1998, the mineral sector (oil in particular) continues to perform well, while the decline in manufacturing output has slowed.

\footnotetext{
${ }^{1}$ Specifically, the nonremunerated deposit requirement on external borrowing was reduced from 30 percent to 25 percent in February 1998, and the period was lowered from 18 months to 12 -month duration. In September 1998 this was further eased to 10 percent and 6-month duration.
} 
Table 6. Colombia: Summary Accounts of the Financial System

\begin{tabular}{|c|c|c|c|c|c|}
\hline & 1995 & 1996 & 1997 & 1998 & $\begin{array}{r}\text { Prel. } \\
\text { Sep. } 1999\end{array}$ \\
\hline \multicolumn{6}{|c|}{ (Annual percentage changes) $1 /$} \\
\hline \multicolumn{6}{|c|}{ I. Financial System 2 / } \\
\hline Net foreign assets & -0.1 & 3.4 & -0.5 & -1.9 & 3.5 \\
\hline Net domestic assets & 25.9 & 28.4 & 22.6 & 12.1 & -0.1 \\
\hline Credit to public sector (net) & -0.6 & 0.0 & 0.1 & 7.1 & 5.2 \\
\hline Quasi-fiscal deficit (surplus -) & -1.3 & 0.0 & 0.2 & -2.4 & -1.6 \\
\hline Credit to private sector & 31.7 & 26.4 & 21.9 & 10.1 & -5.7 \\
\hline Other (net) & -3.9 & 2.1 & 0.4 & -2.8 & 2.1 \\
\hline Liabilities to private sector & 25.8 & 31.9 & 22.2 & 10.2 & 3.3 \\
\hline \multicolumn{6}{|c|}{ II. Banco de la Republica (BR) 3 / } \\
\hline Net international reserves & 11.8 & 52.0 & -0.3 & -46.5 & -37.2 \\
\hline Net domestic assets & 1.0 & -21.1 & 5.9 & 57.4 & 62.7 \\
\hline Credit to public sector (net) & 8.7 & 2.0 & -5.1 & 11.3 & 16.7 \\
\hline Credit to financial system & 6.1 & -26.4 & 1.2 & 57.7 & 27.5 \\
\hline Credit to private sector (net) $4 /$ & 1.1 & 5.1 & 7.4 & 13.7 & 17.4 \\
\hline Other (net) & -14.8 & -1.8 & 2.4 & -25.3 & 1.1 \\
\hline Liabilities to private sector & 12.8 & 31.0 & 5.6 & 10.9 & 25.4 \\
\hline \multicolumn{6}{|l|}{ Memorandum items: } \\
\hline \multicolumn{6}{|c|}{ (Flows in millions of U.S. dollars) } \\
\hline Net official international reserves $5 /$ & 351.1 & $1,540.7$ & -9.3 & $-1,382.7$ & -722.5 \\
\hline \multicolumn{6}{|c|}{ (Annual percentage changes in nominal terms) } \\
\hline Broad money $6 /$ & 27.4 & 30.0 & 24.5 & 10.3 & 3.7 \\
\hline Money (M1) & 26.0 & 19.8 & 24.4 & 13.4 & 9.0 \\
\hline Quasi-money and other & 30.1 & 34.1 & 25.4 & 12.3 & 2.3 \\
\hline Private sector credit & 35.8 & 25.7 & 25.6 & 11.9 & -2.6 \\
\hline Base money & 20.5 & 5.7 & 25.0 & -16.6 & 6.6 \\
\hline \multicolumn{6}{|c|}{ (Annual percentage changes in real terms) } \\
\hline Broad money 6 / & 6.6 & 6.9 & 5.7 & -5.5 & -5.1 \\
\hline Money (M1) & 5.4 & -1.5 & 5.7 & -2.9 & -0.3 \\
\hline Quasi-money and other & 8.9 & 10.3 & 6.6 & -3.7 & -6.4 \\
\hline Private sector credit & 13.7 & 3.4 & 6.7 & -4.1 & -10.9 \\
\hline Base money & 0.8 & -13.0 & 6.2 & -28.5 & -2.5 \\
\hline \multicolumn{6}{|c|}{ (Nominal GDP/broad money) } \\
\hline Velocity of broad money & 3.3 & 2.8 & 3.0 & 2.9 & $\ldots$ \\
\hline \multicolumn{6}{|c|}{ (Interest rates) $7 /$} \\
\hline \multicolumn{6}{|l|}{ 90-day deposit rates } \\
\hline Nominal & 32.4 & 27.8 & 23.9 & 34.6 & 17.5 \\
\hline Real & 10.8 & 5.0 & 5.3 & 15.3 & 7.5 \\
\hline \multicolumn{6}{|l|}{ Lending rates } \\
\hline Nominal & 44.2 & 38.7 & 33.2 & 44.6 & 26.2 \\
\hline Real & 20.7 & 14.1 & 13.2 & 23.9 & 15.4 \\
\hline
\end{tabular}

Sources: Banco de la Republica; and Fund staff estimates.

1/ All annual changes in foreign currency stocks valued at an annual accounting exchange rate.

$2 /$ Changes in relation to private sector liabilities at the beginning of the period. Rates of growth money and quasimoney are with respect to themselves.

3 / Changes in relation to the bank's private sector liabilities at the beginning of the period.

4/ Corresponds mainly to the sum of the stock of open market bills and exchange certificates.

5/ The NIR are equal to the BoP concept of NIR excluding causaciones (accrued, but unpaid, interest on reserve assets).

6/ Includes M3 plus bonds issued by financial institutions.

$7 /$ End of period annual rates. 
12. The fiscal position deteriorated further during the first half of 1999 . The worsening was due primarily to the recession that adversely affected tax revenues, but also to increased spending for reconstruction of the main coffee producing region which was affected by the earthquake in January. Faced with the recession and the growing fiscal imbalances, the government in September announced a medium-term economic program centered on fiscal adjustment and structural reforms. The program calls for (i) reform of the revenue sharing system and the financial operations of territorial governments; (ii) changes in royalty fees in the minerals sector (particularly petroleum) to stimulate foreign direct investment; and (iii) pension system reforms, both at the national and territorial levels, as well as of the special pension regimes for teachers and state oil workers. Moreover, the congress has approved a tight budget for 2000 which calls for a wage freeze for 70 percent of the government employees.

13. Monetary policy was eased in early 1999 as the pressures on prices and the exchange rate abated. The central bank took several steps to reduce reserve requirements on bank deposits and lower the repo rates. These factors, together with a weakening in private sector credit growth contributed to a significant decline in interest rates from their peak in mid-1998. The benchmark 90-days deposit rate and lending rates declined to 17.5 and 26.2 percent by September 1999, respectively, but rates remained relatively high in real terms as inflation came down to 9 percent. Notwithstanding the easing of the monetary policy, financial sector credit to the private sector fell by $2 \frac{1}{2}$ percent year-on-year to September 1999 , owing to the deepening recession, and the growing difficulties facing the financial sector.

14. Growing concerns about the weakening fiscal and financial sectors and the reduction in interest rates contributed to renewed downward pressures on the peso from May, following a period of relative calm. With the scope for a tightening of monetary policy limited by the recession and the weakness in the financial sector, the central bank responded by depreciating the intervention band by 9 percentage points in June and by widening the band from 14 to 20 percentage points. Notwithstanding these measures, the exchange rate remained under pressure reflecting uncertainties about the direction of economic policies, and major credit rating agencies downgraded Colombia's long-term foreign-currency debt to below investment grade. Following large interventions by the central bank to support the peso, the authorities allowed the peso to float at the end of September in the context of the medium-term economic program announced by the authorities. By endSeptember, the central bank's net international reserves had fallen by US\$723 million, to US $\$ 7.9$ billion during 1999. From the time when the peso was floated to end-November, it appreciated by 5 percent against the U.S. dollar.

15. The deepening recession complicated further the problems of the financial sector in 1999. These problems were manifested by a further rise in the nonperforming loans of financial intermediaries, large losses, and a significant deterioration in solvency. The nonperforming loan ratio rose to 14.2 percent in September from 9 percent a year earlier. Three medium-sized credit institutions have been taken over by the authorities, and ten small 
financial institutions have been closed. The most serious difficulties have been faced by the public banks, most of which have been deeply undercapitalized or outright insolvent, with the nonperforming loan ratio rising to over 24 percent in September from 13.2 percent a year earlier.

16. Against this background, the government introduced in 1999 several measures to deal with the weakening of the financial sector, including programs to recapitalize viable private banks and to deal with the public banks. A financial sector reform law was approved in early June which strengthens the faculties of the banking supervisory authorities to deal with troubled banks in a timely manner. The largest public bank (Caja Agraria) was put into liquidation and replaced with a smaller agricultural bank, and the six remaining public banks, including three taken over by the authorities, are under a resolution strategy based on audits, recapitalization and subsequent divestment. In October, the government introduced legislation to provide additional debt relief to the mortgage holders through a debt reduction program.

\section{The external current account position improved significantly in the first half of} 1999 reflecting weak aggregate demand. The trade balance shifted into surplus as imports dropped by 36 percent compared to the same period in 1998. Despite a substantial increase in oil exports and a recovery in prices, total export revenue fell in response to economic difficulties in neighboring Ecuador and Venezuela that slowed the recovery of nontraditional exports. Exports to the United States, on the other hand, increased considerably, helped by the large real depreciation of the peso. The capital account surplus narrowed markedly as foreign direct investment in non-oil sector declined and private portfolio capital outflows continued. However, the public sector inflows remained strong to finance its growing financing needs. 
Table 1. Colombia: National Accounts at Current Prices

\begin{tabular}{|c|c|c|c|c|c|}
\hline & $19941 /$ & 1995 & 1996 & 1997 & $\begin{array}{l}\text { Prel. } \\
1998\end{array}$ \\
\hline \multicolumn{6}{|c|}{ (In billions of Colombian pesos) } \\
\hline Consumption & 54,285 & 68,084 & 84,088 & 103,694 & 123,954 \\
\hline Private sector & 44,510 & 55,462 & 65,966 & 81,235 & 97,065 \\
\hline General government & 9,774 & 12,622 & 18,123 & 22,460 & 26,888 \\
\hline Gross domestic investment & 17,247 & 21,784 & 22,309 & 25,594 & 27,960 \\
\hline Fixed capital formation & 15,727 & 18,911 & 21,749 & 24,832 & 26,528 \\
\hline Private sector & 11,258 & 12,371 & 13,278 & 13,781 & 15,691 \\
\hline Public sector & 4,469 & 6,540 & 8,472 & 11,050 & 10,837 \\
\hline Stockbuilding & 1,520 & 2,873 & 559 & 762 & 1,432 \\
\hline Domestic demand & 71,531 & 89,868 & 106,397 & 129,288 & 151,913 \\
\hline Foreign balance & $-3,998$ & $-5,429$ & $-5,685$ & $-7,637$ & $-9,370$ \\
\hline \multicolumn{6}{|l|}{ Exports of goods and nonfactor } \\
\hline \multicolumn{6}{|l|}{ Imports of goods and nonfactor } \\
\hline services & 14,127 & 17,701 & 20,993 & 25,709 & 30,729 \\
\hline GDP at market prices & 67,533 & 84,439 & 100,711 & 121,651 & 142,543 \\
\hline \multicolumn{6}{|c|}{ (Percentage change) } \\
\hline Consumption & 32.1 & 25.4 & 23.5 & 23.3 & 19.5 \\
\hline Private sector & 28.7 & 24.6 & 18.9 & 23.1 & 19.5 \\
\hline General government & 49.8 & 29.1 & 43.6 & 23.9 & 19.7 \\
\hline Gross domestic investment & 42.8 & 26.3 & 2.4 & 14.7 & 9.2 \\
\hline Fixed capital formation & 47.0 & 20.2 & 15.0 & 14.2 & 6.8 \\
\hline Public sector & 59.2 & 9.9 & 7.3 & 3.8 & 13.9 \\
\hline Private sector & 23.2 & 46.3 & 29.5 & 30.4 & -1.9 \\
\hline Stockbuilding $2 /$ & 9.9 & 2.0 & -2.7 & 0.2 & 0.6 \\
\hline Domestic demand & 34.5 & 25.6 & 18.4 & 21.5 & 17.5 \\
\hline Foreign balance & 94.0 & 35.8 & 4.7 & 34.3 & 22.7 \\
\hline \multicolumn{6}{|l|}{ Exports of goods and nonfactor } \\
\hline services & 23.9 & 21.2 & 24.7 & 18.1 & 18.2 \\
\hline \multicolumn{6}{|l|}{ Imports of goods and nonfactor } \\
\hline services & 38.0 & 25.3 & 18.6 & 22.5 & 19.5 \\
\hline GDP at market prices & 32.1 & 25.0 & 19.3 & 20.8 & 17.2 \\
\hline
\end{tabular}

Sources: Colombian authorities, and staff estimates.

1/ Annual percentage changes are calculated using information for real GDP with base year 1975 .

$2 /$ Changes in percent of preceding year's GDP. 
Table 2. Colombia: National Accounts at Constant Prices

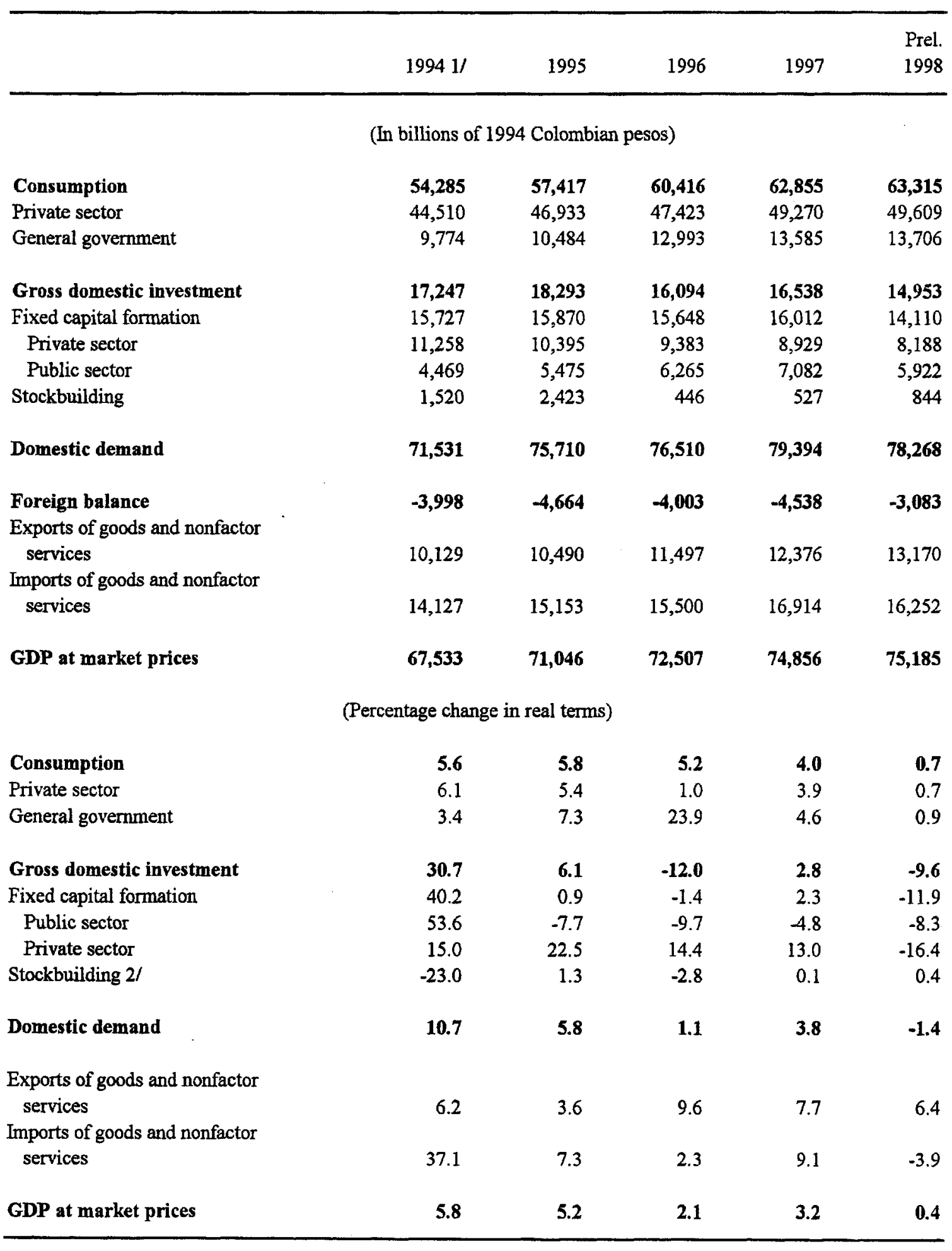

Sources: Colombian authorities, and staff estimates.

1/ Annual percentage changes are calculated using information for real GDP with base year 1975.

$2 /$ Changes in percent of preceding year's GDP. 
Table 3. Colombia: Aggregate Supply and Demand at Constant Prices

\begin{tabular}{|c|c|c|c|c|c|}
\hline & $19941 /$ & 1995 & 1996 & 1997 & $\begin{array}{l}\text { Prel. } \\
1998\end{array}$ \\
\hline \multicolumn{6}{|c|}{ (Annual percentage change at constant 1994 prices) } \\
\hline Aggregate supply & 10.2 & 5.6 & 2.1 & 4.3 & -0.4 \\
\hline GDP & 5.8 & 5.2 & 2.1 & 3.2 & 0.4 \\
\hline \multicolumn{6}{|l|}{ Imports of goods and } \\
\hline nonfactor services & 37.1 & 7.3 & 2.3 & 9.1 & -3.9 \\
\hline Aggregate demand & 10.2 & 5.6 & 2.1 & 4.3 & -0.4 \\
\hline Consumption expenditure & 5.6 & 5.8 & 5.2 & 4.0 & 0.7 \\
\hline Private sector & 6.1 & 5.4 & 1.0 & 3.9 & 0.7 \\
\hline General government & 3.4 & 7.3 & 23.9 & 4.6 & 0.9 \\
\hline Gross domestic investment & 30.7 & 6.1 & -12.0 & 2.8 & -9.6 \\
\hline Fixed capital formation & 40.2 & 0.9 & -1.4 & 2.3 & -11.9 \\
\hline Private sector & 53.6 & -7.7 & -9.7 & -4.8 & -8.3 \\
\hline Nonfinancial public sector & 15.0 & 22.5 & 14.4 & 13.0 & -16.4 \\
\hline Stockbuilding $2 /$ & -23.0 & 1.3 & -2.8 & 0.1 & 0.4 \\
\hline \multicolumn{6}{|l|}{ Exports of goods and } \\
\hline nonfactor services & 6.2 & 3.6 & 9.6 & 7.7 & 6.4 \\
\hline \multicolumn{6}{|c|}{ (In percent of GDP) } \\
\hline Aggregate supply & 120.9 & 121.3 & 121.4 & 122.6 & 121.6 \\
\hline GDP & 100.0 & 100.0 & 100.0 & 100.0 & 100.0 \\
\hline \multicolumn{6}{|l|}{ Imports of goods and } \\
\hline nonfactor services & 20.9 & 21.3 & 21.4 & 22.6 & 21.6 \\
\hline Aggregate demand & 120.9 & 121.3 & 121.4 & 122.6 & 121.6 \\
\hline Consumption expenditure & 80.4 & 80.8 & 83.3 & 84.0 & 84.2 \\
\hline Private sector & 65.9 & 66.1 & 65.4 & 65.8 & 66.0 \\
\hline General government & 14.5 & 14.8 & 17.9 & 18.1 & 18.2 \\
\hline Gross domestic investment & 25.5 & 25.7 & 22.2 & 22.1 & 19.9 \\
\hline Fixed capital formation & 23.3 & 22.3 & 21.6 & 21.4 & 18.8 \\
\hline Private sector & 16.7 & 14.6 & 12.9 & 11.9 & 10.9 \\
\hline Nonfinancial public sector & 6.6 & 7.7 & 8.6 & 9.5 & 7.9 \\
\hline Stockbuilding & 2.3 & 3.4 & 0.6 & 0.7 & 1.1 \\
\hline \multicolumn{6}{|l|}{ Exports of goods and } \\
\hline nonfactor services & 15.0 & 14.8 & 15.9 & 16.5 & 17.5 \\
\hline
\end{tabular}

Sources: Colombian authorities; and Fund staff estimates.

1/ Annual percentage changes are calculated using information for real GDP with base year 1975 .

$2 /$ Changes in percent of preceding year's GDP. 
Table 4. Colombia: Saving and Investment

(In percent of GDP)

\begin{tabular}{|c|c|c|c|c|c|}
\hline & 1994 & 1995 & 1996 & 1997 & $\begin{array}{l}\text { Prel. } \\
1998\end{array}$ \\
\hline Gross national saving & 21.1 & 20.8 & 17.3 & 15.5 & 13.7 \\
\hline Private sector & 14.3 & 13.4 & 11.0 & 9.7 & 8.9 \\
\hline Public sector & 6.8 & 7.4 & 6.3 & 5.8 & 4.8 \\
\hline Gross domestic investment & 25.5 & 25.8 & 22.2 & 21.0 & 19.6 \\
\hline Private sector & 18.6 & 17.8 & 13.5 & 11.5 & 11.7 \\
\hline Fixed capital formation & 16.4 & 15.0 & 13.1 & 11.0 & 10.9 \\
\hline Stockbuilding & 2.1 & 2.8 & 0.5 & 0.5 & 0.8 \\
\hline Public sector capital expenditure & 7.0 & 8.0 & 8.6 & 9.6 & 7.9 \\
\hline \multicolumn{6}{|l|}{ External current account } \\
\hline balance & -4.4 & -5.0 & -4.9 & -5.5 & -5.9 \\
\hline Financing & 3.9 & 5.1 & 5.1 & 6.1 & 6.1 \\
\hline Capital account (net) & 4.2 & 5.1 & 6.9 & 6.3 & 4.7 \\
\hline \multicolumn{6}{|l|}{ Change in net international } \\
\hline reserves (increase -) & 0.2 & 0.0 & 1.8 & 0.2 & -1.4 \\
\hline
\end{tabular}

Sources: Colombian authorities; and Fund staff estimates. 
Table 5. Colombia: Value of Agricultural Crops 1/

(Percentage changes; at constant 1975 prices)

\begin{tabular}{|c|c|c|c|c|c|}
\hline & 1994 & 1995 & 1996 & 1997 & $\begin{array}{l}\text { Prel. } \\
1998\end{array}$ \\
\hline Total & -2.3 & 3.3 & -5.6 & -1.8 & -1.4 \\
\hline Coffee & -11.8 & 13.8 & -18.3 & -4.3 & 19.4 \\
\hline Cotton & -19.3 & 0.4 & 26.0 & -40.8 & -11.2 \\
\hline Bananas & 2.0 & -18.0 & -7.1 & 8.4 & -5.8 \\
\hline Sugar cane & 7.1 & 5.3 & 3.9 & -0.6 & -0.5 \\
\hline Blond tobacco & -46.9 & -3.3 & 49.8 & -1.5 & 2.3 \\
\hline Black tobacco & -13.2 & -6.7 & -16.6 & -33.3 & 114.3 \\
\hline Corn & 2.8 & -12.2 & -5.2 & 1.1 & -22.8 \\
\hline Rice & 4.2 & 7.7 & -6.9 & 10.2 & 3.7 \\
\hline Potatoes & 2.7 & -1.6 & -3.1 & -3.0 & -6.2 \\
\hline Wheat & 9.2 & -29.5 & -12.8 & -22.3 & -22.2 \\
\hline Barley & -20.5 & -22.1 & -11.8 & -52.1 & -36.2 \\
\hline Yucca & -5.6 & 0.4 & 12.1 & -17.0 & -4.7 \\
\hline Plantains & -4.7 & 17.5 & -5.6 & 0.8 & -9.5 \\
\hline Cocoa & -11.9 & 11.9 & -12.4 & 1.4 & 0.7 \\
\hline Soybean & -3.4 & -13.2 & -38.8 & 55.4 & -20.3 \\
\hline Sorghum & 2.5 & -14.7 & -19.7 & -25.9 & -42.6 \\
\hline Vegetables & 2.3 & 2.3 & 2.0 & 4.4 & -14.7 \\
\hline
\end{tabular}

Sources: Ministry of Agriculture; and National Department of Statistics (DANE).

1/ Calculated on the basis of changes in the volume of output as estimated by the Ministry of Agriculture. 
Table 6. Colombia: Coffee Stocks, Production, Exports, and Prices

\begin{tabular}{|c|c|c|c|c|c|c|c|}
\hline & \multirow[b]{2}{*}{1994} & \multirow[b]{2}{*}{1995} & \multirow[b]{2}{*}{1996} & \multirow[b]{2}{*}{1997} & \multirow{2}{*}{$\begin{array}{l}\text { Prel. } \\
1998\end{array}$} & \multicolumn{2}{|c|}{ Jan.-Sep. } \\
\hline & & & & & & 1998 & 1999 \\
\hline \multicolumn{8}{|c|}{ (In thousands of $60-\mathrm{kg}$ bags) } \\
\hline Opening registered stocks & 6,298 & 4,821 & 7,350 & 6,350 & 4,638 & 4,638 & 62.8 \\
\hline Derived production & 12,032 & 13,698 & 11,190 & 10,704 & 12,783 & 8,497 & 5,920 \\
\hline Domestic consumption $1 /$ & 1,734 & 1,353 & 1,569 & 1,483 & 1,481 & 1,099 & 1,064 \\
\hline Exportable production & 10,298 & 12,345 & 9,621 & 9,221 & 11,302 & 7,398 & 4,856 \\
\hline Registered exports & 11,775 & 9,816 & 10,621 & 10,933 & 11,240 & 7,980 & 6,372 \\
\hline To ICO members & 9,137 & 7,026 & 7,223 & 7,104 & 7,272 & 5,302 & 3,569 \\
\hline To nonmembers & 2,638 & 2,790 & 3,398 & 3,829 & 3,968 & 2,678 & 2,803 \\
\hline Change in registered stocks & $-1,477$ & 2,529 & $-1,000$ & $-1,712$ & 63 & -582 & $-1,515$ \\
\hline \multicolumn{8}{|c|}{ (In Colombian pesos per $125 \mathrm{~kg}$ load) } \\
\hline \multicolumn{8}{|l|}{ Domestic purchase price of } \\
\hline Coffee Federation & 164,179 & 200,998 & 212,371 & 332,780 & 315,871 & 317,518 & 340,199 \\
\hline \multicolumn{8}{|c|}{ (In U.S. cents per pound) } \\
\hline International coffee price $2 /$ & 157.8 & 158.9 & 131.1 & 188.3 & 142.5 & 150.0 & 114.2 \\
\hline \multicolumn{8}{|l|}{ Domestic purchase price of } \\
\hline Coffee Federation 3 / & 88.8 & 98.5 & 91.6 & 130.5 & 99.1 & 112.5 & 99.0 \\
\hline \multicolumn{8}{|l|}{ Memorandum item: } \\
\hline \multicolumn{8}{|l|}{ Average exchange rate } \\
\hline (Colombian pesos per U.S. dollar) & 826.5 & 912.5 & $1,036.7$ & $1,140.5$ & $1,426.3$ & $1,262.3$ & $1,536.4$ \\
\hline
\end{tabular}

Sources: International Coffee Organization (ICO); National Federation of Coffee Growers; and Fund staff estimates.

1/ Registered domestic sales of semiprocesed coffee by the Coffee Federation.

2/ As measured by the indicator price for Colombian mild Arabica coffee.

3/ A 125-kg load is equal to 214.34 pounds of green coffee. 
Table 7. Colombia: Coffee Output and Exports by Calendar and Coffee Years (In thousands of $60-\mathrm{kg}$ bags)

\begin{tabular}{|c|c|c|c|c|}
\hline & \multirow[b]{2}{*}{$\begin{array}{l}\text { Registered } \\
\text { Production }\end{array}$} & \multirow[b]{2}{*}{$\begin{array}{r}\text { Coffee } \\
\text { Federation }\end{array}$} & \multicolumn{2}{|c|}{ Registered Exports } \\
\hline & & & $\begin{array}{l}\text { Private } \\
\text { Exporters }\end{array}$ & Tota \\
\hline 1994 - Year ended September & 11,421 & 4,589 & 8,101 & 12,690 \\
\hline October - December & 4,698 & 951 & 1,925 & 2,876 \\
\hline Year ended December & 12,031 & 4,240 & 7,535 & 11,775 \\
\hline 1995 - Year ended September & 12,964 & 3,420 & 5,924 & 9,344 \\
\hline October - December & 5,431 & 1,049 & 2,290 & 3,339 \\
\hline Year ended December & 13,697 & 3,518 & 6,298 & 9,816 \\
\hline 1996 - Year ended September & 12,938 & 6,491 & 4,313 & 10,804 \\
\hline October - December & 3,683 & 1,094 & 2,071 & 3,165 \\
\hline Year ended December & 11,190 & 4,237 & 6,384 & 10,621 \\
\hline 1997 - Year ended September & 10,779 & 4,053 & 7,148 & 11,201 \\
\hline October - December & 3,608 & 961 & 1,936 & 2,898 \\
\hline Year ended December & 10,704 & 3,921 & 7,013 & 10,933 \\
\hline 1998 - Year ended September & 12,123 & 3706.2 & 7171.7 & 10,878 \\
\hline October - December & 4269 & 847.9 & 2393.3 & 3,241 \\
\hline Year ended December & 12784 & 3592.7 & $7,647.3$ & 11,240 \\
\hline 1999 - Year ended September & 10,868 & 2964.9 & $7,326.4$ & 10,291 \\
\hline
\end{tabular}

Source: National Federation of Coffee Growers. 
Table 8. Colombia: Volume of Manufacturing Production 1/

(Annual percentage change)

\begin{tabular}{|c|c|c|c|c|c|c|}
\hline & \multirow[b]{2}{*}{1995} & \multirow[b]{2}{*}{1996} & \multirow[b]{2}{*}{1997} & \multirow{2}{*}{$\begin{array}{l}\text { Prel. } \\
1998\end{array}$} & \multicolumn{2}{|c|}{ Jan.-Jun. } \\
\hline & & & & & 1998 & 1999 \\
\hline Total industrial production & 2.2 & -2.0 & 1.9 & -1.7 & 6.5 & -19.8 \\
\hline Food products & 2.7 & 3.9 & -0.2 & 1.7 & 2.7 & -7.8 \\
\hline Beverages & 8.7 & -8.1 & 2.5 & -2.0 & 4.6 & -18.5 \\
\hline Tobacco & -15.6 & 14.6 & -5.0 & 1.6 & 1.7 & 9.4 \\
\hline Textiles & 5.2 & 2.6 & -1.1 & -3.2 & 7.6 & -21.4 \\
\hline Footwear and clothing & -1.8 & 5.4 & 12.4 & 44.7 & 49.1 & -20.7 \\
\hline Leather goods & -15.8 & -24.0 & 13.9 & 0.0 & 7.8 & -15.1 \\
\hline Shoes & -9.3 & -19.1 & -3.2 & 0.3 & 0.4 & -34.0 \\
\hline Wood industry & -12.1 & -28.2 & -5.2 & -10.1 & -1.3 & -28.0 \\
\hline Wood furniture & 3.5 & -50.3 & 13.1 & -7.9 & -4.6 & -35.1 \\
\hline Paper and paper products & 8.5 & -10.0 & 0.0 & 7.9 & 18.0 & -13.7 \\
\hline Printing and related products & -7.9 & -4.0 & 3.9 & 2.0 & 8.8 & -23.9 \\
\hline Chemicals industry & 8.8 & -8.4 & -2.9 & -6.5 & -4.6 & -17.6 \\
\hline Other chemicals & 2.4 & -6.6 & 5.8 & -1.1 & 9.1 & -21.5 \\
\hline Petroleum derivatives & 1.6 & 20.3 & -2.3 & -3.8 & -10.3 & 12.8 \\
\hline $\begin{array}{l}\text { Other petroleum and coal } \\
\text { derivatives }\end{array}$ & 5.2 & -7.3 & 1.0 & -8.8 & -0.7 & -19.4 \\
\hline Rubber goods & -15.5 & -13.4 & -14.0 & -13.1 & -2.4 & -21.6 \\
\hline Plastic goods & -3.2 & 0.3 & 4.8 & 0.7 & 5.1 & -13.6 \\
\hline Mud and porcelain goods & -0.4 & -0.6 & 15.5 & 4.1 & 18.6 & -26.5 \\
\hline Glass and glass products & 3.2 & -8.3 & 11.1 & -12.8 & -4.4 & -37.7 \\
\hline Nonmetallic minerals & 1.0 & .11 .2 & -6.5 & -8.4 & -1.5 & -34.7 \\
\hline Iron and steel industries & 1.7 & -4.1 & 15.3 & -9.5 & -0.6 & -18.1 \\
\hline Noniron industries & 4.3 & -11.7 & 1.4 & -2.4 & 10.2 & -34.9 \\
\hline Metallic products, & 6.8 & -2.3 & 7.0 & -7.7 & -4.3 & -11.3 \\
\hline excluding machinery & 0 & 0 & 0 & 0.0 & 0.0 & 0.0 \\
\hline $\begin{array}{l}\text { Machinery, excluding } \\
\text { electric machinery }\end{array}$ & 0.9 & -19.4 & 3.4 & -9.8 & 3.8 & -34.9 \\
\hline Electric machinery & -7.7 & -4.4 & 15.1 & -11.9 & 13.1 & -37.7 \\
\hline Transport equipment & 1.0 & -9.1 & 7.9 & -8.7 & 24.5 & -57.1 \\
\hline \multicolumn{7}{|l|}{ Scientific professional } \\
\hline equipment & 33.2 & 17.6 & 2.4 & 1.1 & 4.2 & -12.3 \\
\hline
\end{tabular}

Source: National Department of Statistics (DANE).

1/ Excluding the coffee husking process. 
Table 9. Colombia: Mining Production

\begin{tabular}{|c|c|c|c|c|c|c|}
\hline & \multirow[b]{2}{*}{1995} & \multirow[b]{2}{*}{1996} & \multirow[b]{2}{*}{1997} & \multirow{2}{*}{$\begin{array}{l}\text { Prel. } \\
1998\end{array}$} & \multicolumn{2}{|c|}{ Jan.-Jun. } \\
\hline & & & & & 1998 & 1999 \\
\hline \multicolumn{7}{|c|}{ (In units as specified) } \\
\hline Petroleum (millions of barrels) & 213.5 & 229.3 & 238.0 & 275.5 & 129.7 & 150.1 \\
\hline Gold (thousands of troy ounces) & 194.7 & 48.9 & 17.4 & 7.3 & 3.6 & 3.8 \\
\hline Platinum (thousands of troy ounces) & 26.7 & 6.1 & 7.5 & 3.5 & 2.0 & 1.2 \\
\hline Silver (thousands of troy ounces) & 21.5 & 5.9 & 2.0 & 0.9 & 0.5 & 0.4 \\
\hline Iron ore (thousands of tons) & 571.6 & 605.7 & 754.8 & 525.8 & 266.4 & 299.5 \\
\hline Coal (millions of tons) & 25.8 & 29.6 & 32.7 & 33.7 & 14.0 & 15.6 \\
\hline \multirow[t]{2}{*}{ Salt (thousands of tons) $1 /$} & 281.4 & 560.3 & 374.6 & 495.7 & 245.7 & 190.4 \\
\hline & \multicolumn{3}{|c|}{ (Percentage change) } & & \multicolumn{2}{|c|}{$\begin{array}{r}\text { Jan.-Jun. 99/ } \\
\text { Jan.-Jun. } 98\end{array}$} \\
\hline Petroleum (millions of barrels) & 28.9 & 7.4 & 3.8 & 15.7 & $\ldots$ & 15.7 \\
\hline Gold (thousands of troy ounces) & -71.2 & -74.9 & -64.6 & -57.7 & $\ldots$ & 3.8 \\
\hline Platinum (thousands of troy ounces) & -26.6 & -77.2 & 23.9 & -53.2 & $\ldots$ & -38.2 \\
\hline Silver (thousands of troy ounces) & -88.5 & -72.7 & -65.2 & -54.3 & $\ldots$ & -14.6 \\
\hline Iron ore (thousands of tons) & 3.5 & 6.0 & 24.6 & -30.3 & ... & 12.4 \\
\hline Coal (millions of tons) & 14.2 & 14.7 & 10.5 & 3.1 & $\ldots$ & 11.1 \\
\hline Salt (thousands of tons) & 107.1 & 99.1 & -33.1 & 32.3 & $\ldots$ & -22.5 \\
\hline
\end{tabular}

Sources: ECOPETROL; ECOCARBON; and Ministry of Mines and Energy.

1/ Sea water salt and mineral salt. 
Table 10. Colombia: National Production and Consumption of Petroleum Products

\begin{tabular}{|c|c|c|c|c|c|c|}
\hline & \multirow[b]{2}{*}{1995} & \multirow[b]{2}{*}{1996} & \multirow[b]{2}{*}{1997} & \multirow{2}{*}{$\begin{array}{l}\text { Prel. } \\
1998\end{array}$} & \multicolumn{2}{|c|}{ Jan.-Jun. } \\
\hline & & & & & 1998 & 1999 \\
\hline \multicolumn{7}{|c|}{ (In thousands of barrels per day) } \\
\hline Total production & 584.9 & 626.3 & 652.2 & 754.3 & 671.6 & 836.5 \\
\hline ECOPETROL & 112.6 & 115.7 & 119.3 & 115.8 & 118.8 & 104.4 \\
\hline Partnerships & 460.1 & 495.4 & 517.5 & 622.1 & 537.2 & 714.8 \\
\hline Concessions & 12.2 & 15.2 & 15.4 & 16.5 & 15.6 & 17.4 \\
\hline Total refinery output & 249.2 & 269.2 & 265.5 & 262.6 & 261.1 & 281.5 \\
\hline Total consumption & 309.0 & 321.5 & 350.0 & 351.1 & 375.5 & 317.4 \\
\hline $\begin{array}{l}\text { White products } 1 / \\
\text { Of which }\end{array}$ & 217.6 & 226.3 & 232.4 & 231.1 & 261.1 & 218.5 \\
\hline Gasoline & 128.6 & 128.9 & 131.0 & 129.5 & 99.9 & 97.5 \\
\hline Black products and & & & & & & \\
\hline natural gas $2 /$ & 91.4 & 95.2 & 117.7 & 127.0 & 114.4 & 98.9 \\
\hline \multicolumn{7}{|c|}{ (Percentage change) } \\
\hline Total production & 28.8 & 7.1 & 4.1 & 15.7 & $\ldots$ & 24.6 \\
\hline ECOPETROL & 17.9 & 2.7 & 3.2 & -3.0 & $\ldots$ & -12.1 \\
\hline Partnerships & 40.2 & 7.7 & 4.5 & 20.2 & $\ldots$ & 33.1 \\
\hline Concessions & -59.9 & 24.9 & 1.3 & 7.1 & $\ldots$ & 11.4 \\
\hline Total refinery output & 1.1 & 8.0 & -1.4 & -1.1 & $\cdots$ & 7.8 \\
\hline Total consumption & 5.7 & 4.1 & 8.9 & 0.3 & ... & -15.5 \\
\hline $\begin{array}{l}\text { White products } 1 / \\
\text { Of which }\end{array}$ & 4.8 & 4.0 & 2.7 & -0.5 & $\ldots$ & -16.3 \\
\hline Gasoline & 4.4 & 0.2 & 1.7 & -1.1 & $\ldots$ & -2.4 \\
\hline \multicolumn{7}{|l|}{ Black products and } \\
\hline natural gas 2/ & 8.0 & 4.1 & 23.7 & 7.9 & $\ldots$ & -13.6 \\
\hline
\end{tabular}

Source: ECOPETROL.

1/ White products include regular and premium gasoline, industrial benzene, kerosene, jet fuel, and propane.

2/ Black products comprise crude oil as fuel and diesel fuel oil; and natural gas expressed in equivalent fuel-oil barrels. 
Table 11. Colombia: Structure of Regular Gasoline Prices

(End of period)

\begin{tabular}{|c|c|c|c|c|c|c|}
\hline & 1994 & 1995 & 1996 & 1997 & $\begin{array}{l}\text { Prel. } \\
1998\end{array}$ & $\begin{array}{c}\text { Sep. } \\
1999\end{array}$ \\
\hline \multicolumn{7}{|c|}{ (In Colombian pesos per gallon) } \\
\hline Prices to public & 688.0 & 773.0 & 933.6 & $1,175.0$ & $1,434.0$ & $2,223.4$ \\
\hline Prices at refinery & 126.2 & 345.0 & 392.4 & 659.8 & 772.3 & 989.8 \\
\hline Taxes & 262.5 & 303.4 & 392.8 & 294.0 & 400.8 & 544.6 \\
\hline Highway tax & 159.6 & 168.9 & 330.0 & 189.4 & 277.2 & 385.5 \\
\hline Sales tax & 59.6 & 68.4 & 62.8 & 105.6 & 123.6 & 158.4 \\
\hline Department tax & 1.4 & 1.6 & 0.0 & 0.0 & 0.0 & 0.0 \\
\hline Other & 41.9 & 64.5 & 0.0 & 0.0 & 0.0 & 0.0 \\
\hline Transportation charges & 244.0 & 70.0 & 83.0 & 97.9 & 113.6 & 159.1 \\
\hline Distribution & 55.3 & 54.7 & 65.5 & 100.5 & 120.6 & 130.0 \\
\hline \multicolumn{7}{|c|}{ (Annual percentage change) } \\
\hline Prices to public & 19.0 & 12.4 & 20.8 & 25.9 & 22.0 & 55.0 \\
\hline Prices at refinery & 19.0 & 173.5 & 13.7 & 68.2 & 17.0 & 28.2 \\
\hline Taxes & 29.0 & 15.6 & 29.5 & -25.1 & 36.3 & 35.9 \\
\hline Transportation charges & 9.4 & -71.3 & 18.6 & 18.0 & 16.0 & 40.0 \\
\hline Distribution & 21.8 & -1.2 & 19.7 & 53.4 & 20.0 & 7.8 \\
\hline \multicolumn{7}{|c|}{ (In U.S. cents per gallon) } \\
\hline Prices to public & 82.8 & 78.3 & 92.9 & 90.8 & 93.0 & 112.6 \\
\hline Prices at refinery & 15.2 & 34.9 & 39.0 & 51.0 & 50.1 & 50.1 \\
\hline \multicolumn{7}{|l|}{ Memorandum items: } \\
\hline \multicolumn{7}{|l|}{ Exchange rate (Colombian } \\
\hline peso per U.S. dollar) & 831.2 & 987.7 & $1,005.3$ & $1,293.6$ & $1,542.1$ & $1,975.0$ \\
\hline \multicolumn{7}{|l|}{ Ratio of prices to public } \\
\hline and at refinery (changes) & 1.0 & 0.1 & 1.5 & 0.4 & 1.3 & 2.0 \\
\hline
\end{tabular}

Source: Ministry of Mines and Energy. 
Table 12. Colombia: Indicators of Construction Activity

(Average percentage change, unless otherwise indicated)

\begin{tabular}{lccccc}
\hline & 1995 & 1996 & 1997 & 1998 & $\begin{array}{r}\text { Jan. 98- } \\
\text { Jun. 99 }\end{array}$ \\
& & & & & \\
\hline $\begin{array}{l}\text { Total approved construction } \\
\quad \text { licenses (area) 1/2/ }\end{array}$ & -10.5 & -29.3 & 11.9 & -23.1 & -40.2 \\
$\begin{array}{l}\text { Approved licenses for housing } \\
\text { construction (area) 1/2/ }\end{array}$ & -15.0 & -34.4 & 25.9 & -22.1 & -47.6 \\
$\begin{array}{l}\text { Construction costs } \\
\quad \text { (at current prices) 3/ }\end{array}$ & 12.6 & -2.2 & 4.2 & 11.6 & -1.6 \\
$\begin{array}{l}\text { Steel } \\
\text { Cement } \\
\text { Brick }\end{array}$ & 17.0 & 31.0 & 22.4 & 21.1 & 29.6 \\
$\quad$ & 22.4 & 5.1 & 9.2 & 4.2 & 1.0 \\
Cement production (volume) & 0.2 & -6.9 & 3.3 & -4.7 & -20.1 \\
Steel production (volume) & 14.9 & 1.3 & 15.6 & -19.6 & 28.5 \\
\hline
\end{tabular}

Sources: Colombian Construction Board (CAMACOL);Banco de la República and National Department of Statistics (DANE).

1/ Construction licenses are no longer required in Bogota, effective 1993.

2/ September 1998/September 1997.

3/ Index of producer prices, Banco de la República. 
Table 13. Colombia: Quarterly Survey of Unemployment and Participation Rates (In percent)

\begin{tabular}{|c|c|c|c|c|c|}
\hline & Total $1 /$ & Barranquilla & Bogota & Cali & Medellin \\
\hline \multicolumn{6}{|c|}{ I. Unemployment Rates } \\
\hline 1994 & 8.9 & 9.9 & 6.3 & 9.1 & 11.6 \\
\hline 1995 & 8.8 & 10.5 & 7.0 & 9.8 & 10.5 \\
\hline 1996 & 11.2 & 11.7 & 9.3 & 14.1 & 12.6 \\
\hline 1997 & 12.4 & 11.7 & 10.1 & 17.3 & 14.5 \\
\hline 1998 & 15.2 & 12.0 & 14.0 & 19.5 & 16.2 \\
\hline 1999 & 19.7 & 16.3 & 18.5 & 21.2 & 22.4 \\
\hline \multicolumn{6}{|l|}{1994} \\
\hline March & 10.2 & 11.3 & 8.1 & 10.8 & 13.2 \\
\hline June & 9.9 & 11.8 & 7.7 & 10.3 & 11.9 \\
\hline September & 7.6 & 10.1 & 4.9 & 11.3 & 8.6 \\
\hline December & 8.0 & 8.8 & 7.2 & 6.9 & 8.4 \\
\hline \multicolumn{6}{|l|}{1995} \\
\hline March & 8.1 & 9.8 & 6.5 & 9.1 & 9.2 \\
\hline June & 9.0 & 8.3 & 7.8 & 11.2 & 9.8 \\
\hline September & 8.7 & 11.2 & 6.3 & 10.1 & 10.9 \\
\hline December & 9.5 & 10.1 & 7.6 & 10.8 & 11.9 \\
\hline \multicolumn{6}{|l|}{1996} \\
\hline March & 10.2 & 10.9 & 8.2 & 13.1 & 11.6 \\
\hline June & 11.4 & 12.5 & 9.5 & 14.4 & 12.0 \\
\hline September & 11.9 & 12.1 & 10.3 & 14.9 & 13.3 \\
\hline December & 11.3 & 11.2 & 9.1 & 14.0 & 13.5 \\
\hline \multicolumn{6}{|l|}{1997} \\
\hline March & 12.3 & 12.8 & 8.5 & 17.2 & 16.3 \\
\hline June & 13.3 & 11.4 & 11.4 & 18.4 & 15.3 \\
\hline September & 12.1 & 12.1 & 9.9 & 17.0 & 13.8 \\
\hline December & 12.0 & 10.6 & 10.6 & 16.6 & 12.4 \\
\hline \multicolumn{6}{|l|}{1998} \\
\hline March & 14.4 & 13.0 & 12.7 & 17.9 & 16.3 \\
\hline June & 15.9 & 13.0 & 14.8 & 19.7 & 16.7 \\
\hline September & 15.0 & 11.6 & 13.3 & 20.6 & 15.8 \\
\hline December & 15.7 & 10.4 & 15.3 & 19.6 & 15.8 \\
\hline \multicolumn{6}{|l|}{1999} \\
\hline March & 19.5 & 16.7 & 18.0 & 21.2 & 23.1 \\
\hline June & 19.8 & 16.3 & 19.0 & 21.3 & 21.6 \\
\hline September & 20.1 & 16.5 & 19.3 & 22.3 & 22.3 \\
\hline
\end{tabular}


Table 13. Colombia: Quarterly Survey of Unemployment and Participation Rates

(In percent)

\begin{tabular}{|c|c|c|c|c|c|}
\hline & Total $1 /$ & Barranquilla & Bogota & Cali I & dellin \\
\hline \multicolumn{6}{|c|}{ II. Participation Rates } \\
\hline 1994 & 59.8 & 54.0 & 61.9 & 60.2 & 57.8 \\
\hline 1995 & 59.9 & 54.2 & 62.6 & 58.9 & 56.9 \\
\hline 1996 & 59.7 & 54.1 & 61.6 & 58.6 & 57.4 \\
\hline 1997 & 59.9 & 54.9 & 60.5 & 62.3 & 58.4 \\
\hline 1998 & 62.2 & 56.2 & 63.3 & 64.9 & 60.0 \\
\hline 1999 & 62.5 & 57.1 & 63.7 & 66.1 & 60.0 \\
\hline \multicolumn{6}{|l|}{1994} \\
\hline March & 60.5 & 54.3 & 62.1 & 60.4 & 59.6 \\
\hline June & 59.8 & 54.0 & 61.4 & 59.9 & 57.9 \\
\hline September & 59.0 & 53.1 & 60.6 & 60.8 & 56.9 \\
\hline December & 60.6 & 54.5 & 63.5 & 59.8 & 56.8 \\
\hline \multicolumn{6}{|l|}{1995} \\
\hline March & 59.2 & 55.3 & 61.3 & 59.6 & 55.9 \\
\hline June & 59.4 & 50.7 & 62.7 & 58.7 & 57.1 \\
\hline September & 59.4 & 53.6 & 62.0 & 58.8 & 56.1 \\
\hline December & 61.4 & 57.3 & 64.3 & 58.4 & 58.4 \\
\hline \multicolumn{6}{|l|}{1996} \\
\hline March & 60.6 & 55.1 & 63.4 & 59.9 & 57.5 \\
\hline June & 59.1 & 54.2 & 60.6 & 58.5 & 56.8 \\
\hline September & 59.1 & 52.6 & 61.3 & 57.5 & 56.9 \\
\hline December & 59.8 & 54.5 & 61.1 & 58.3 & 58.4 \\
\hline \multicolumn{6}{|l|}{1997} \\
\hline March & 58.3 & 54.7 & 57.8 & 59.4 & 58.7 \\
\hline June & 59.9 & 55.4 & 60.0 & 63.2 & 58.4 \\
\hline September & 59.9 & 53.8 & 61.5 & 62.6 & 57.4 \\
\hline December & 61.5 & 55.6 & 62.6 & 63.8 & 59.1 \\
\hline \multicolumn{6}{|l|}{1998} \\
\hline March & 62.3 & 57.0 & 63.6 & 64.2 & 60.0 \\
\hline June & 62.7 & 56.6 & 63.9 & 64.5 & 60.8 \\
\hline September & 61.0 & 54.6 & 61.0 & 65.5 & 60.0 \\
\hline December & 62.7 & 56.5 & 64.7 & 65.3 & 59.0 \\
\hline \multicolumn{6}{|l|}{1999} \\
\hline March & 62.3 & 59.1 & 63.6 & 63.7 & 60.0 \\
\hline June & 62.8 & 55.2 & 63.8 & 68.5 & 59.9 \\
\hline September & 63.3 & 56.7 & 64.0 & 63.8 & 61.0 \\
\hline
\end{tabular}

Source: National Department of Statistics (DANE).

1/ For seven metropolitan areas (Bogota, Medellin, Cali, Barranquilla, Bucaramanga, Giron, and Manizales). 
Table 14. Colombia: Minimum Wages

\begin{tabular}{|c|c|c|c|}
\hline & $\begin{array}{r}\text { Nominal Values } \\
\text { (Col\$ per day) }\end{array}$ & $\begin{array}{c}\text { Salario } \\
\text { Real }\end{array}$ & $\begin{array}{l}\text { Index } 1 / \\
988=100 \text { ) }\end{array}$ \\
\hline 1994 & $3,290.00$ & 818.31 & 95.76 \\
\hline 1995 & $3,964.45$ & 825.29 & 96.57 \\
\hline 1996 & $4,737.50$ & 813.15 & 95.15 \\
\hline 1997 & $5,733.50$ & 831.04 & 97.25 \\
\hline 1998 & $6,794.20$ & 836.72 & 97.91 \\
\hline \multicolumn{4}{|l|}{1994} \\
\hline January & $3,290.00$ & 975.74 & 114.18 \\
\hline December & $3,290.00$ & 818.31 & 95.76 \\
\hline \multicolumn{4}{|l|}{1995} \\
\hline January & $3,964.45$ & 968.36 & 113.32 \\
\hline December & $3,964.50$ & 825.30 & 96.58 \\
\hline \multicolumn{4}{|l|}{1996} \\
\hline January & $4,737.50$ & 959.55 & 112.28 \\
\hline December & $4,737.50$ & 813.15 & 95.15 \\
\hline \multicolumn{4}{|l|}{1997} \\
\hline January & $5,733.50$ & 965.72 & 113.01 \\
\hline December & $5,733.50$ & 831.04 & 97.25 \\
\hline \multicolumn{4}{|l|}{1998} \\
\hline January & $6,794.20$ & 966.13 & 113.05 \\
\hline December & $6,794.20$ & 836.72 & 97.91 \\
\hline \multicolumn{4}{|l|}{1999} \\
\hline January & $7,882.00$ & 946.22 & 110.72 \\
\hline June & $7,882.00$ & 907.02 & 106.14 \\
\hline
\end{tabular}

Source: National Department of Statistics (DANE).

1/ Deflated by the consumer price index for low-income workers. 
Table 15. Colombia: Nominal and Real Wage Indicators in Manufacturing 1/

\begin{tabular}{|c|c|c|c|c|c|c|}
\hline & $\begin{array}{c}\text { Nominal } \\
\text { Wage }\end{array}$ & $\begin{array}{c}\text { Real } \\
\text { Wage 2/ }\end{array}$ & $\begin{array}{r}\text { Unit } \\
\text { Labor Cost }\end{array}$ & $\begin{array}{r}\text { Nominal } \\
\text { Wage }\end{array}$ & $\begin{array}{r}\text { Real } \\
\text { Wage 2/ }\end{array}$ & $\begin{array}{r}\text { Unit } \\
\text { Labor Cost }\end{array}$ \\
\hline & \multicolumn{3}{|c|}{ (Index: 1990=100) } & \multicolumn{3}{|c|}{ (Percentage change) $3 /$} \\
\hline 1994 & & & & & & \\
\hline $\begin{array}{l}\text { March } \\
\text { June } \\
\text { September } \\
\text { December }\end{array}$ & $\begin{array}{l}245.5 \\
254.8 \\
257.8 \\
275.8\end{array}$ & $\begin{array}{l}105.8 \\
102.6 \\
100.9 \\
104.3\end{array}$ & $\begin{array}{l}228.7 \\
225.3 \\
215.5 \\
233.4\end{array}$ & $\begin{array}{l}26.3 \\
20.7 \\
22.5 \\
24.2\end{array}$ & $\begin{array}{r}2.6 \\
-2.9 \\
-0.3 \\
1.1\end{array}$ & $\begin{array}{l}19.3 \\
13.0 \\
12.6 \\
15.9\end{array}$ \\
\hline $\begin{array}{l}1995 \\
\text { March } \\
\text { June } \\
\text { September } \\
\text { December }\end{array}$ & $\begin{array}{l}292.8 \\
323.8 \\
319.6 \\
338.2\end{array}$ & $\begin{array}{l}104.0 \\
107.6 \\
103.3 \\
106.6\end{array}$ & $\begin{array}{l}248.8 \\
270.4 \\
253.8 \\
259.7\end{array}$ & $\begin{array}{l}19.3 \\
27.1 \\
24.0 \\
22.7\end{array}$ & $\begin{array}{r}-1.7 \\
4.9 \\
2.4 \\
2.2\end{array}$ & $\begin{array}{r}8.8 \\
20.0 \\
17.7 \\
11.3\end{array}$ \\
\hline $\begin{array}{l}1996 \\
\text { March } \\
\text { June } \\
\text { September } \\
\text { December }\end{array}$ & $\begin{array}{l}359.2 \\
393.8 \\
389.9 \\
407.7\end{array}$ & $\begin{array}{l}105.8 \\
109.8 \\
104.9 \\
105.8\end{array}$ & $\begin{array}{l}291.0 \\
314.8 \\
304.2 \\
318.3\end{array}$ & $\begin{array}{l}22.7 \\
21.6 \\
22.0 \\
20.5\end{array}$ & $\begin{array}{r}1.7 \\
2.0 \\
1.5 \\
-0.8\end{array}$ & $\begin{array}{l}17.0 \\
16.4 \\
19.9 \\
22.6\end{array}$ \\
\hline \multicolumn{7}{|l|}{1997} \\
\hline $\begin{array}{l}\text { March } \\
\text { June } \\
\text { September } \\
\text { December }\end{array}$ & $\begin{array}{l}462.3 \\
479.0 \\
465.5 \\
510.1\end{array}$ & $\begin{array}{l}114.3 \\
112.6 \\
105.2 \\
111.6\end{array}$ & $\begin{array}{l}371.1 \\
346.9 \\
324.3 \\
341.4\end{array}$ & $\begin{array}{l}28.7 \\
21.6 \\
19.4 \\
25.1\end{array}$ & $\begin{array}{l}8.0 \\
2.6 \\
0.3 \\
5.5\end{array}$ & $\begin{array}{r}27.6 \\
10.2 \\
6.6 \\
7.3\end{array}$ \\
\hline \multicolumn{7}{|l|}{1998} \\
\hline March & 546.8 & 112.1 & 384.9 & 18.3 & -1.9 & 3.7 \\
\hline June & 587.2 & 111.8 & 418.4 & 22.6 & -0.7 & 20.6 \\
\hline September & 563.8 & 105.5 & 401.2 & 21.1 & 0.3 & 23.7 \\
\hline December & 599.3 & 111.3 & 431.9 & 17.5 & -0.3 & 26.5 \\
\hline \multicolumn{7}{|l|}{1999} \\
\hline $\begin{array}{l}\text { March } \\
\text { June }\end{array}$ & $\begin{array}{l}639.0 \\
681.5\end{array}$ & $\begin{array}{l}113.3 \\
118.1\end{array}$ & $\begin{array}{l}\ldots \\
\ldots\end{array}$ & $\begin{array}{l}16.9 \\
16.1\end{array}$ & $\begin{array}{l}1.1 \\
5.6\end{array}$ & $\begin{array}{l}\ldots \\
\cdots\end{array}$ \\
\hline September & 665.2 & 114.2 & $\ldots$ & 18.0 & 8.2 & $\ldots$ \\
\hline
\end{tabular}

Source: National Department of Statistics (DANE).

1/ Including only production workers; excluding coffee husking activities.

2/ Nominal wage deflated by consumer price index.

3/ From corresponding period of previous year. 
Table 16. Colombia: Producer Price Index

\begin{tabular}{|c|c|c|c|c|c|}
\hline & \multicolumn{2}{|c|}{ Consumption } & \multirow{2}{*}{$\begin{array}{c}\text { Raw } \\
\text { Materials }\end{array}$} & \multirow{2}{*}{$\begin{array}{c}\text { Capital } \\
\text { Goods } 1 /\end{array}$} & \multirow{2}{*}{$\begin{array}{r}\text { Construction } \\
\text { Materials }\end{array}$} \\
\hline & Total & Goods & & & \\
\hline \multicolumn{6}{|c|}{ (Annual average percentage changes) } \\
\hline 1994 & 17.2 & 19.7 & 16.1 & 12.6 & 15.9 \\
\hline 1995 & 18.1 & 18.3 & 19.1 & 13.2 & 13.6 \\
\hline 1996 & 15.0 & 16.7 & 13.9 & 15.0 & 14.1 \\
\hline 1997 & 15.4 & 17.5 & 14.7 & 9.9 & 14.4 \\
\hline 1998 & 17.3 & 20.6 & 15.4 & 14.8 & 13.9 \\
\hline \multicolumn{6}{|c|}{ (12-month percentage change) } \\
\hline \multicolumn{6}{|l|}{1994} \\
\hline March & 15.5 & 18.8 & 13.2 & 13.0 & 19.5 \\
\hline June & 15.7 & 19.4 & 13.7 & 12.9 & 14.3 \\
\hline September & 18.6 & 21.3 & 18.1 & 12.0 & 14.3 \\
\hline December & 20.7 & 21.6 & 21.8 & 12.7 & 14.6 \\
\hline \multicolumn{6}{|l|}{1995} \\
\hline March & 18.7 & 18.2 & 20.2 & 13.5 & 14.1 \\
\hline June & 21.5 & 21.7 & 23.2 & 12.9 & 13.5 \\
\hline September & 17.2 & 17.8 & 17.7 & 13.0 & 13.7 \\
\hline December & 15.4 & 15.8 & 15.6 & 14.2 & 11.7 \\
\hline \multicolumn{6}{|l|}{1996} \\
\hline March & 16.3 & 18.5 & 15.1 & 16.4 & 11.8 \\
\hline June & 13.0 & 13.2 & 12.5 & 15.6 & 15.0 \\
\hline September & 14.4 & 16.5 & 12.8 & 15.0 & 15.3 \\
\hline December & 14.5 & 17.9 & 12.5 & 11.8 & 14.4 \\
\hline \multicolumn{6}{|l|}{1997} \\
\hline March & 14.0 & 14.4 & 14.1 & 9.6 & 15.0 \\
\hline June & 17.1 & 17.3 & 18.4 & 8.4 & 13.9 \\
\hline September & 16.1 & 19.5 & 14.7 & 8.9 & 13.2 \\
\hline December & 17.5 & 19.3 & 16.6 & 13.3 & 17.5 \\
\hline \multicolumn{6}{|l|}{1998} \\
\hline March & 18.6 & 21.4 & 17.2 & 13.8 & 16.8 \\
\hline June & 17.6 & 26.3 & 12.1 & 14.7 & 10.8 \\
\hline September & 16.5 & 18.9 & 14.9 & 16.0 & 13.4 \\
\hline December & 13.5 & 15.2 & 12.2 & 14.5 & 12.4 \\
\hline \multicolumn{6}{|l|}{1999} \\
\hline March & 9.4 & 12.3 & 6.6 & 11.9 & 12.6 \\
\hline June & 6.1 & 3.5 & 6.6 & 12.1 & 16.7 \\
\hline September & 10.9 & 10.6 & 13.2 & 20.1 & 14.3 \\
\hline
\end{tabular}

Source: Banco de la Republica.

1/ Excluding construction materials. 
Table 17. Colombia: Items Subject to Price Controls 1/

(In percentage weight of middle-income group $\mathrm{CPD}$

\begin{tabular}{|c|c|c|c|c|c|c|c|c|c|c|}
\hline & \multicolumn{2}{|c|}{ December 1995} & \multicolumn{2}{|c|}{ December 1996} & \multicolumn{2}{|c|}{ December 1997} & \multicolumn{2}{|c|}{ December 1998} & \multicolumn{2}{|c|}{ September 1999} \\
\hline & $\begin{array}{r}\text { Direct } \\
\text { Controls }\end{array}$ & $\begin{array}{c}\text { Indirect } \\
\text { Controls }\end{array}$ & $\begin{array}{r}\text { Direct } \\
\text { Controls }\end{array}$ & $\begin{array}{r}\text { Indirect } \\
\text { Controls }\end{array}$ & $\begin{array}{r}\text { Direct } \\
\text { Controls }\end{array}$ & $\begin{array}{l}\text { Indirect } \\
\text { Controls }\end{array}$ & $\begin{array}{r}\text { Direct } \\
\text { Controls }\end{array}$ & $\begin{array}{l}\text { Indirect } \\
\text { Controls }\end{array}$ & $\begin{array}{r}\text { Direct } \\
\text { Controls }\end{array}$ & $\begin{array}{r}\text { Indirect } \\
\text { Controls }\end{array}$ \\
\hline Total & 30.1 & 1.5 & 30.1 & 1.5 & 30.1 & 1.5 & 30.1 & 1.5 & 33.4 & 1.8 \\
\hline Food items & 0.0 & 0.1 & 0.0 & 0.1 & 0.0 & 0.1 & 0.0 & 0.1 & 0.0 & 0.1 \\
\hline Sugar 2/ & 0.0 & 0.0 & 0.0 & 0.0 & 0.0 & 0.0 & 0.0 & 0.0 & 0.0 & 0.0 \\
\hline Salt & 0.0 & 0.1 & 0.0 & 0.1 & 0.0 & 0.1 & 0.0 & 0.1 & 0.0 & 0.1 \\
\hline Carbonated beverages 3 / & 0.0 & 0.0 & 0.0 & 0.0 & 0.0 & 0.0 & 0.0 & 0.0 & 0.0 & 0.0 \\
\hline Milk & 0.0 & 0.0 & 0.0 & 0.0 & 0.0 & 0.0 & 0.0 & 0.0 & 0.0 & 0.0 \\
\hline Housing items & 23.8 & 0.0 & 23.8 & 0.0 & 23.8 & 0.0 & 23.8 & 0.0 & 24.9 & 0.0 \\
\hline Rent & 20.1 & 0.0 & 20.1 & 0.0 & 20.1 & 0.0 & 20.1 & 0.0 & 20.7 & 0.0 \\
\hline Gasoline-diesel & 0.0 & 0.0 & 0.0 & 0.0 & 0.0 & 0.0 & 0.0 & 0.0 & 0.0 & 0.0 \\
\hline Public utilities & 3.7 & 0.0 & 3.7 & 0.0 & 3.7 & 0.0 & 3.7 & 0.0 & 4.2 & 0.0 \\
\hline Other items & 6.3 & 1.4 & 6.3 & 1.4 & 6.3 & 1.4 & 6.3 & 1.4 & 8.5 & 1.7 \\
\hline Drugs & 0.0 & 1.4 & 0.0 & 1.4 & 0.0 & 1.4 & 0.0 & 1.4 & 0.0 & 1.7 \\
\hline Bus fares & 2.4 & 0.0 & 2.4 & 0.0 & 2.4 & 0.0 & 2.4 & 0.0 & 3.1 & 0.0 \\
\hline Taxi fares & 0.7 & 0.0 & 0.7 & 0.0 & 0.7 & 0.0 & 0.7 & 0.0 & 1.1 & 0.0 \\
\hline Beer 3/ & 0.0 & 0.0 & 0.0 & 0.0 & 0.0 & 0.0 & 0.0 & 0.0 & 0.0 & 0.0 \\
\hline \multicolumn{11}{|l|}{ Boarding fees and } \\
\hline school tuition & 2.5 & 0.0 & 2.5 & 0.0 & 2.5 & 0.0 & 2.5 & 0.0 & 3.2 & 0.0 \\
\hline Gasoline & 0.8 & 0.0 & 0.8 & 0.0 & 0.8 & 0.0 & 0.8 & 0.0 & 1.1 & 0.0 \\
\hline
\end{tabular}

Source: Banco de la Republica.

1/ Direct control: the increment in prices has to be approved by the government. Indirect control: the increment in prices is proposed by the producer to the government 15 days in advance of the due date, and the increment in price takes effect if the government does not disapprove the proposal.

2/ Includes both refined and unrefined sugar.

3/ Surveillance over producers, but not consumers. 
Table 18. Colombia: Operations of the Combined Public Sector

(In billions of Colombian pesos)

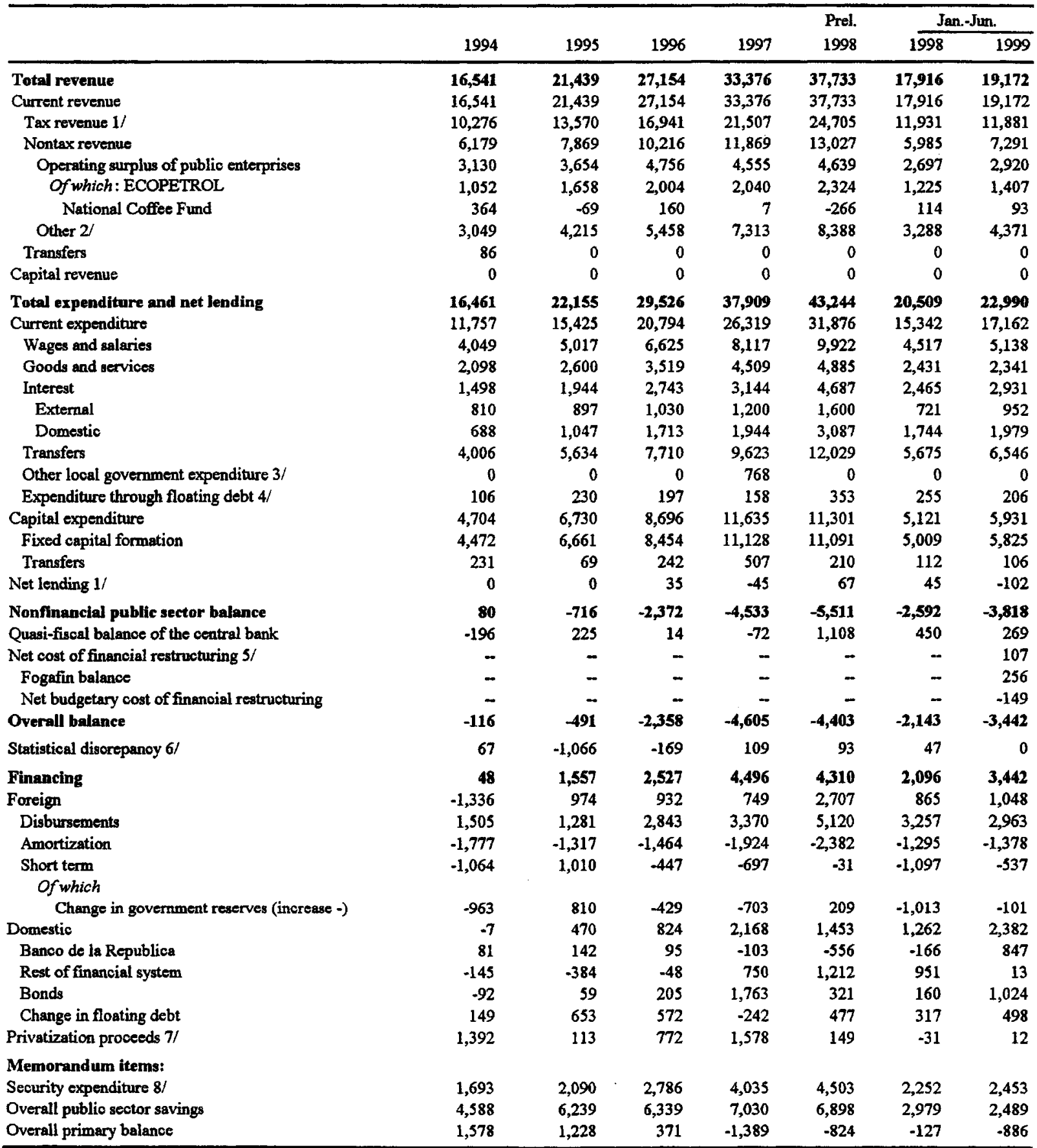

Sources: Ministry of Finance and Public Credit; and Banco de la Republica.

1/ Excludes proceeds of financial transaction tax in 1999 from revenue and expenditure.

$2 /$ Includes looal fees, penalties and oil stabilization fund.

3/ Includes expenditure financed by increase in floating debt and, beginning in 1997 based on financing data, an adjustment for unrecorded local government expenditure.

4/ Includes expenditure on an accrual basis not included in other outlays.

5/ Transfer to Caja Agraria in 1999, interest payments on public banks restructuring bonds and mortgage debt relief related costs.

$6 /$ Includes residual differences between items above and below the line.

$7 /$ Includes nonreourrent fees from telecommunications licensing.

8/ Includes army and police wages and purchases of goods and services. 
Table 19. Colombia: Operations of the Central Administration

(In billions of Colombian pesos)

\begin{tabular}{|c|c|c|c|c|c|c|c|}
\hline & \multirow[b]{2}{*}{1994} & \multirow[b]{2}{*}{1995} & \multirow[b]{2}{*}{1996} & \multirow[b]{2}{*}{1997} & \multirow{2}{*}{$\begin{array}{l}\text { Prel. } \\
1998\end{array}$} & \multicolumn{2}{|c|}{ Jan.-Sep. } \\
\hline & & & & & & $\overline{1998}$ & 1999 \\
\hline Total revenue & 7,849 & 9,723 & 11,958 & 15,291 & 16,789 & 12,338 & 13,344 \\
\hline Current revenue & $\mathbf{7 , 8 3 4}$ & 9,723 & 11,863 & 15,291 & 16,789 & 12,338 & 13,344 \\
\hline Tax revenue $1 /$ & 6,731 & 8,185 & 10,172 & 13,148 & 14,825 & 11,144 & 11,286 \\
\hline Net income tax and profits & 2,813 & 3,394 & 3,856 & 5,341 & 6,109 & 4,780 & 5,277 \\
\hline Goods and services & 3,175 & 3,893 & 5,378 & 6,473 & 7,048 & 5,068 & 4,938 \\
\hline Value-added tax & 2,769 & 3,428 & 4,740 & 5,837 & 6,406 & 4,589 & 4,397 \\
\hline Gasoline tax & 406 & 466 & 637 & 636 & 642 & 479 & 541 \\
\hline International trade & 721 & 880 & 913 & 1,241 & 1,647 & 1,279 & 1,052 \\
\hline Stamp and other taxes & 23 & 18 & 25 & 93 & 21 & 17 & 19 \\
\hline Nontax revenue & 703 & 1,135 & 1,193 & 1,157 & 1,353 & 905 & 1,020 \\
\hline Property income & 125 & 141 & 298 & 378 & 362 & 274 & 183 \\
\hline Other & 578 & 993 & 895 & 779 & 991 & 630 & 837 \\
\hline Current transfers & 400 & 403 & 498 & 986 & 611 & 289 & 1,038 \\
\hline Capital receipts & 16 & $\mathbf{0}$ & 95 & $\mathbf{0}$ & $\mathbf{0}$ & 0 & $\mathbf{0}$ \\
\hline Total expenditure and net lending & 8,777 & 12,116 & 16,474 & 19,511 & 24,245 & 18,377 & 20,362 \\
\hline Current expenditure & 6,815 & 8,948 & 11,895 & 14,875 & 19,348 & 14,292 & 16,041 \\
\hline Wages and salaries & 1,662 & 2,059 & 2,525 & 3,068 & 3,779 & 2,697 & 3,021 \\
\hline Goods and services & 702 & 989 & 1,328 & 1,901 & 1,975 & 1,604 & 1,314 \\
\hline Interest & 412 & 593 & 1,078 & 1,491 & 2,722 & 2,267 & 3,130 \\
\hline External & 386 & 466 & 496 & 760 & 1,041 & 833 & 1,353 \\
\hline Domestic & 26 & 127 & 582 & 732 & 1,681 & 1,433 & 1,777 \\
\hline Other expenditure $2 /$ & 106 & 230 & 197 & 158 & 353 & 330 & 227 \\
\hline Current transfers $3 /$ & 3,933 & 5,076 & 6,767 & 8,258 & 10,518 & 7,394 & 8,348 \\
\hline Capital expenditure & 1,833 & 2,996 & 4,159 & 4,432 & 4,575 & $\mathbf{3 , 8 1 9}$ & 4,151 \\
\hline Fixed capital formation, cash basis & 807 & 1,182 & 1,571 & 2,225 & 1,624 & 1,259 & 747 \\
\hline Other expenditure 21 & 43 & 423 & 494 & -434 & 78 & 59 & 438 \\
\hline Capital transfers & 983 & 1,391 & 2,094 & 2,642 & 2,872 & 2,502 & 2,966 \\
\hline Net lending $1 /$ & 129 & 172 & 420 & 203 & 323 & 266 & 171 \\
\hline Overall balance & -928 & $-2,392$ & $-4,516$ & $-4,220$ & $-7,457$ & $-6,039$ & $-7,018$ \\
\hline \multicolumn{8}{|l|}{ Memorandum items: } \\
\hline Current transfers to territorial governments & 2,235 & 2,792 & 3,988 & 4,907 & 6,088 & 3,749 & 4,440 \\
\hline Current account balance & 1,019 & 776 & -32 & 416 & $-2,559$ & $-1,954$ & $-2,697$ \\
\hline
\end{tabular}

Sources: Ministry of Finance and Public Credit.

1/ Excludes proceeds of financial transaction tax in 1999 from revenue and expenditure.

$2 /$ Expenditure on an accrual basis not included in other outlays.

$3 /$ Includes interest payments to the rest of the nonfinancial public sector. 
Table 20. Colombia: Operations of the Central Administration

(In percent of GDP)

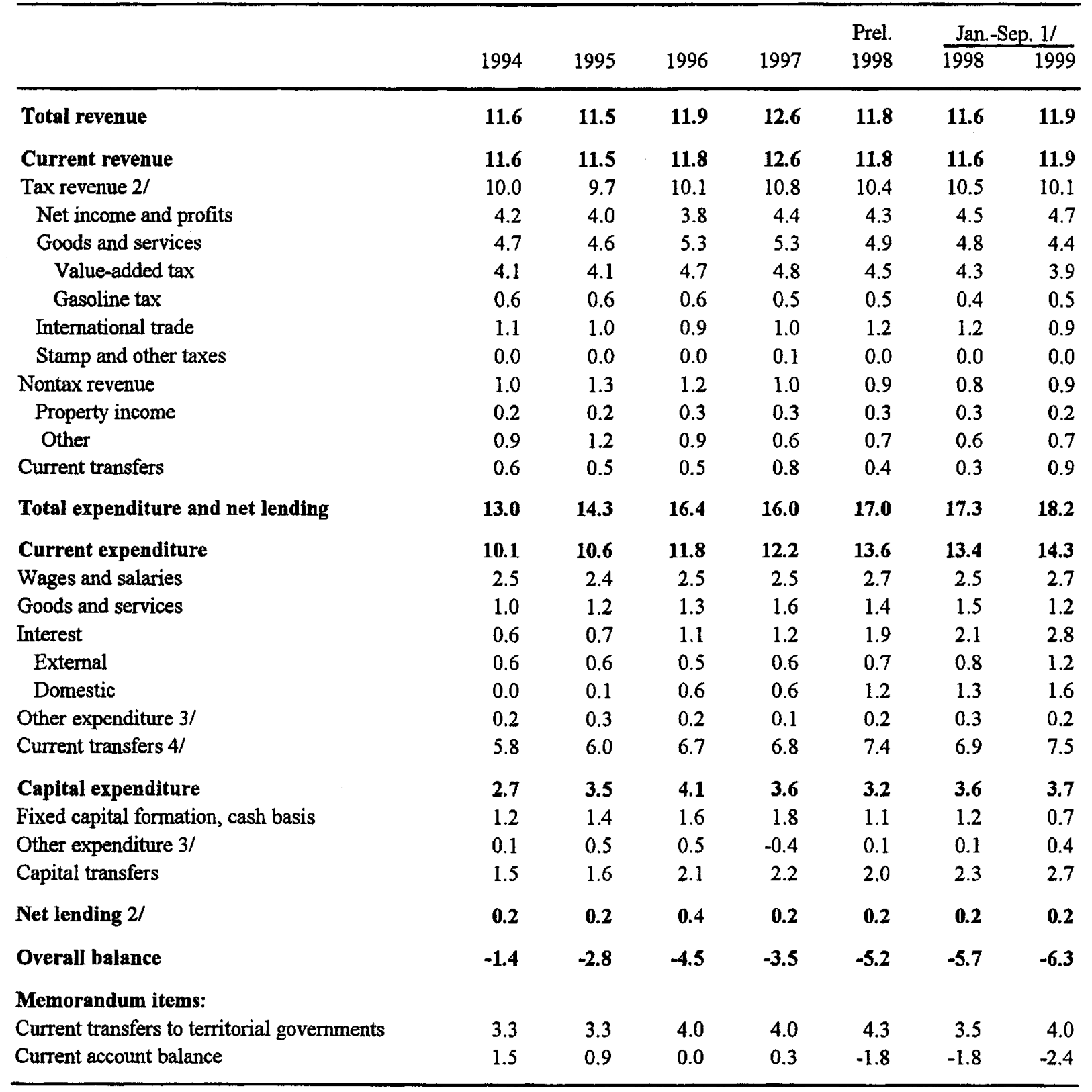

Source: Ministry of Finance and Public Credit.

$1 /$ In percent of estimated GDP of the period.

2/ Excludes proceeds of financial transaction tax in 1999 from revenue and expenditure.

3/ Expenditure on an accrual basis not included in other outlays.

4/ Includes interest payments to the rest of the nonfinancial public sector. 
Table 21. Colombia: Operations of the Social Security System 1/

\begin{tabular}{|c|c|c|c|c|c|c|c|}
\hline & \multirow[b]{2}{*}{1994} & \multirow[b]{2}{*}{1995} & \multirow[b]{2}{*}{1996} & \multirow[b]{2}{*}{1997} & \multirow{2}{*}{$\begin{array}{l}\text { Prel. } \\
1998\end{array}$} & \multicolumn{2}{|c|}{ Jan.-Jun. } \\
\hline & & & & & & 1998 & 1999 \\
\hline \multicolumn{8}{|c|}{ (In billions of Colombian pesos) } \\
\hline Total revenue & 3,364 & 5,436 & 7,667 & 8,862 & 11,318 & 5,312 & 6,035 \\
\hline Current revenue & 3,293 & 5,338 & 7,238 & 8,761 & 11,101 & 5,247 & 5,998 \\
\hline Social security contributions & 1,648 & 2,929 & 3,569 & 4,030 & 4,848 & 2,269 & 1,955 \\
\hline Nontax revenue & 184 & 382 & 788 & 1,051 & 1,811 & 639 & 921 \\
\hline \multicolumn{8}{|l|}{ Of which } \\
\hline Fees and charges & 45 & 234 & 483 & 599 & 1,114 & 460 & 502 \\
\hline $\begin{array}{l}\text { Transfers received } \\
\text { Of which }\end{array}$ & \multicolumn{6}{|c|}{ Of which } & 3,122 \\
\hline From central administration & 1,321 & 1,872 & 2,704 & 3,462 & 4,100 & 2,209 & 2,945 \\
\hline Capital revenue & 71 & 98 & 429 & 100 & 218 & 65 & 37 \\
\hline Total expenditure and net lending & 2,668 & 3,804 & 5,611 & 7,369 & 9,084 & 4,053 & 4,810 \\
\hline Current expenditure & 2,649 & 3,763 & 5,546 & 7,267 & 9,039 & 4,023 & 4,791 \\
\hline Wages and salaries & 213 & 262 & 293 & 475 & 670 & 331 & 393 \\
\hline Goods and services & 453 & 665 & 1,030 & 1,242 & 1,326 & 579 & 567 \\
\hline Interest & 0 & 0 & 0 & 3 & 0 & 2 & 1 \\
\hline Transfers to private sector & 1,984 & 2,836 & 4,223 & 5,547 & 7,044 & 3,110 & 3,830 \\
\hline $\begin{array}{l}\text { Capital expenditure and net lending } \\
\text { Of which }\end{array}$ & 19 & 42 & 64 & 102 & 44 & 31 & 19 \\
\hline Fixed capital formation & 17 & 36 & 52 & 69 & 56 & 17 & 10 \\
\hline Overall balance & 696 & 1,632 & 2,057 & 1,492 & 2,235 & 1,259 & 1,225 \\
\hline \multicolumn{8}{|l|}{ Memorandum item: } \\
\hline Current account balance & 644 & 1,575 & 1,692 & 1,494 & 2,061 & 1,224 & 1,207 \\
\hline \multicolumn{8}{|c|}{ (In percent of GDP) } \\
\hline Total revenue & 5.0 & 6.4 & 7.6 & 7.3 & 7.9 & 7.6 & 8.2 \\
\hline Total expenditure and net lending & 4.0 & 4.5 & 5.6 & 6.1 & 6.4 & 5.8 & 6.5 \\
\hline Overall balance & 1.0 & 1.9 & 2.0 & 1.2 & 1.6 & 1.8 & 1.7 \\
\hline
\end{tabular}

Source: Ministry of Finance and Public Credit.

1/ Includes the social security, CAJANAL (only through 1998), and other funds covering employees of the central administration. 
Table 22. Colombia: Operations of the National Decentralized Agencies 1/

\begin{tabular}{|c|c|c|c|c|c|c|c|}
\hline & \multirow[b]{2}{*}{1994} & \multirow[b]{2}{*}{1995} & \multirow[b]{2}{*}{1996} & \multirow[b]{2}{*}{1997} & \multirow{2}{*}{$\begin{array}{l}\text { Prel. } \\
1998\end{array}$} & \multicolumn{2}{|c|}{ Jan.-Jun. } \\
\hline & & & & & & $\overline{1998}$ & 1999 \\
\hline \multicolumn{8}{|c|}{ (In billions of Colombian pesos) } \\
\hline Total revenue & 1,325 & 1,554 & 1,990 & 2,452 & 2,350 & 1,239 & 1,309 \\
\hline Current revenue & 917 & 1,113 & 1,379 & 1,603 & 1,810 & 923 & 997 \\
\hline Tax revenue & 431 & 548 & 709 & 867 & 1,028 & 523 & 581 \\
\hline Nontax revenue & 328 & 378 & 385 & 552 & 452 & 224 & 220 \\
\hline Goods and services & 83 & 95 & 61 & 10 & 0 & 0 & 0 \\
\hline Property income & 0 & 0 & 0 & 0 & 0 & 0 & 0 \\
\hline Other & 245 & 283 & 324 & 542 & 452 & 224 & 220 \\
\hline Transfers $2 /$ & 158 & 187 & 285 & 184 & 330 & 176 & 196 \\
\hline Capital revenue & 409 & 441 & 611 & 849 & 540 & 316 & 311 \\
\hline Total expenditure and net lending & 1,178 & 1,512 & 1,793 & 2,400 & 2,339 & 1,263 & 1,407 \\
\hline Current expenditure & 699 & 864 & 997 & 1,179 & 1,423 & 685 & 689 \\
\hline Wages and salaries & 130 & 177 & 199 & 243 & 279 & 109 & 121 \\
\hline Employment contributions & 9 & 15 & 27 & 34 & 39 & 17 & 18 \\
\hline Income and corporate taxes & 0 & 0 & 8 & 0 & 0 & 0 & 0 \\
\hline Goods and services & 212 & 246 & 158 & 161 & 152 & 66 & 71 \\
\hline Interest & 62 & 61 & 55 & 25 & 168 & 85 & 32 \\
\hline External & 49 & 57 & 7 & 19 & 104 & 52 & 17 \\
\hline Domestic & 12 & 4 & 49 & 6 & 64 & 33 & 16 \\
\hline Transfers & 286 & 365 & 550 & 717 & 784 & 407 & 446 \\
\hline Capital expenditure & 533 & 714 & 888 & 1,269 & 1,048 & 640 & 730 \\
\hline Fixed capital formation & 498 & 694 & 824 & 1,180 & 977 & 608 & 714 \\
\hline Transfers & 35 & 19 & 64 & 88 & 70 & 32 & 17 \\
\hline Net lending & -54 & -65 & -93 & -48 & -132 & -62 & -12 \\
\hline Overall balance & 147 & 42 & 197 & 52 & 12 & -24 & -98 \\
\hline \multicolumn{8}{|l|}{ Memorandum item: } \\
\hline Current account balance & 218 & 250 & 382 & 423 & 387 & 238 & 308 \\
\hline \multicolumn{8}{|c|}{ (In percent of GDP) } \\
\hline Total revenue & 2.0 & 1.8 & 2.0 & 2.0 & 1.6 & 1.8 & 1.8 \\
\hline Total expenditure and net lending & 1.7 & 1.8 & 1.8 & 2.0 & 1.6 & 1.8 & 1.9 \\
\hline Overall balance & 0.2 & 0.0 & 0.2 & 0.0 & 0.0 & 0.0 & -0.1 \\
\hline
\end{tabular}

Source: Ministry of Finance and Public Credit.

$1 /$ Includes the road construction fund; and agricultural and social agencies.

$2 /$ Includes statistical discrepancies resulting from differences in intersectoral transfers. 
Table 23. Colombia: Operations of the Central Government $1 /$

\begin{tabular}{|c|c|c|c|c|c|c|c|}
\hline & \multirow[b]{2}{*}{1994} & \multirow[b]{2}{*}{1995} & \multirow[b]{2}{*}{1996} & \multirow[b]{2}{*}{1997} & \multirow{2}{*}{$\begin{array}{l}\text { Prel. } \\
1998\end{array}$} & \multicolumn{2}{|c|}{ Jan -Jun. } \\
\hline & & & & & & 1998 & 1999 \\
\hline \multicolumn{8}{|c|}{ (In billions of Colombian pesos) } \\
\hline Total revenue & 10,653 & 14,228 & 17,999 & 22,085 & 25,468 & 11,977 & 12,199 \\
\hline Current revenue & 10,567 & 14,129 & 17,475 & 21,984 & 25,250 & 11,911 & 12,162 \\
\hline Tax revenue & 8,809 & 11,663 & 14,449 & 18,046 & 20,701 & 10,285 & 10,079 \\
\hline Nontax revenue & 1,204 & 1,879 & 2,331 & 2,725 & 3,576 & 1,378 & 1,788 \\
\hline Transfers & 553 & 587 & 695 & 1,214 & 972 & 249 & 295 \\
\hline Capital revenue & 86 & 98 & 524 & 100 & 218 & 65 & 37 \\
\hline Total expenditure and net lending & 10,765 & 14,975 & 20,304 & 24,838 & 30,737 & 15,117 & 16,445 \\
\hline Current expenditure & 8,687 & $\mathbf{1 1 , 5 3 7}$ & 15,448 & 19,678 & 25,396 & 11,988 & 13,241 \\
\hline Wages and salaries & 2,005 & 2,498 & 3,017 & 3,785 & 4,728 & 2,204 & 2,431 \\
\hline Goods and services & 1,366 & 1,900 & 2,516 & 3,304 & 3,453 & 1,786 & 1,581 \\
\hline Interest & 474 & 654 & 1,133 & 1,519 & 2,891 & 1,753 & 1,942 \\
\hline External & 435 & 523 & 503 & 779 & 1,146 & 571 & 668 \\
\hline Domestic & 39 & 131 & 630 & 740 & 1,745 & 1,182 & 1,274 \\
\hline Transfers & 4,736 & 6,254 & 8,585 & 10,912 & 13,971 & 5,991 & 7,081 \\
\hline Other current expenditure $2 /$ & 106 & 230 & 197 & 158 & 353 & 255 & 206 \\
\hline Capital expenditure & 2,002 & 3,331 & 4,529 & 5,005 & 5,151 & 3,016 & 3,134 \\
\hline Fixed capital formation & 1,365 & 2,335 & 2,941 & 3,040 & 2,736 & 1,609 & 1,475 \\
\hline Transfers & 637 & 996 & 1,589 & 1,966 & 2,415 & 1,406 & 1,658 \\
\hline Net lending & 76 & 107 & 327 & 155 & 190 & 113 & 71 \\
\hline Overall balance & -112 & -748 & $-2,305$ & $-2,753$ & $-5,270$ & $-3,141$ & $-4,246$ \\
\hline \multicolumn{8}{|l|}{ Memorandum item: } \\
\hline Current account balance & 1,880 & 2,592 & 2,027 & 2,307 & -146 & -77 & $-1,079$ \\
\hline \multicolumn{8}{|c|}{ (In percent of GDP) } \\
\hline Total revenue & 15.8 & 16.8 & 17.9 & 18.2 & 17.9 & 17.1 & 16.5 \\
\hline Total expenditure and net lending & 15.9 & 17.7 & 20.2 & 20.4 & 21.6 & 21.5 & 22.3 \\
\hline Overall balance & -0.2 & -0.9 & -2.3 & -2.3 & -3.7 & -4.5 & -5.8 \\
\hline
\end{tabular}

Source: Ministry of Finance and Public Credit.

1/ Includes central administration; social security; and national decentralized agencies.

2/ Expenditure on an accrual basis not included in other outlays. 
Table 24. Colombia: Operations of the Local Nonfinancial Public Sector 1/

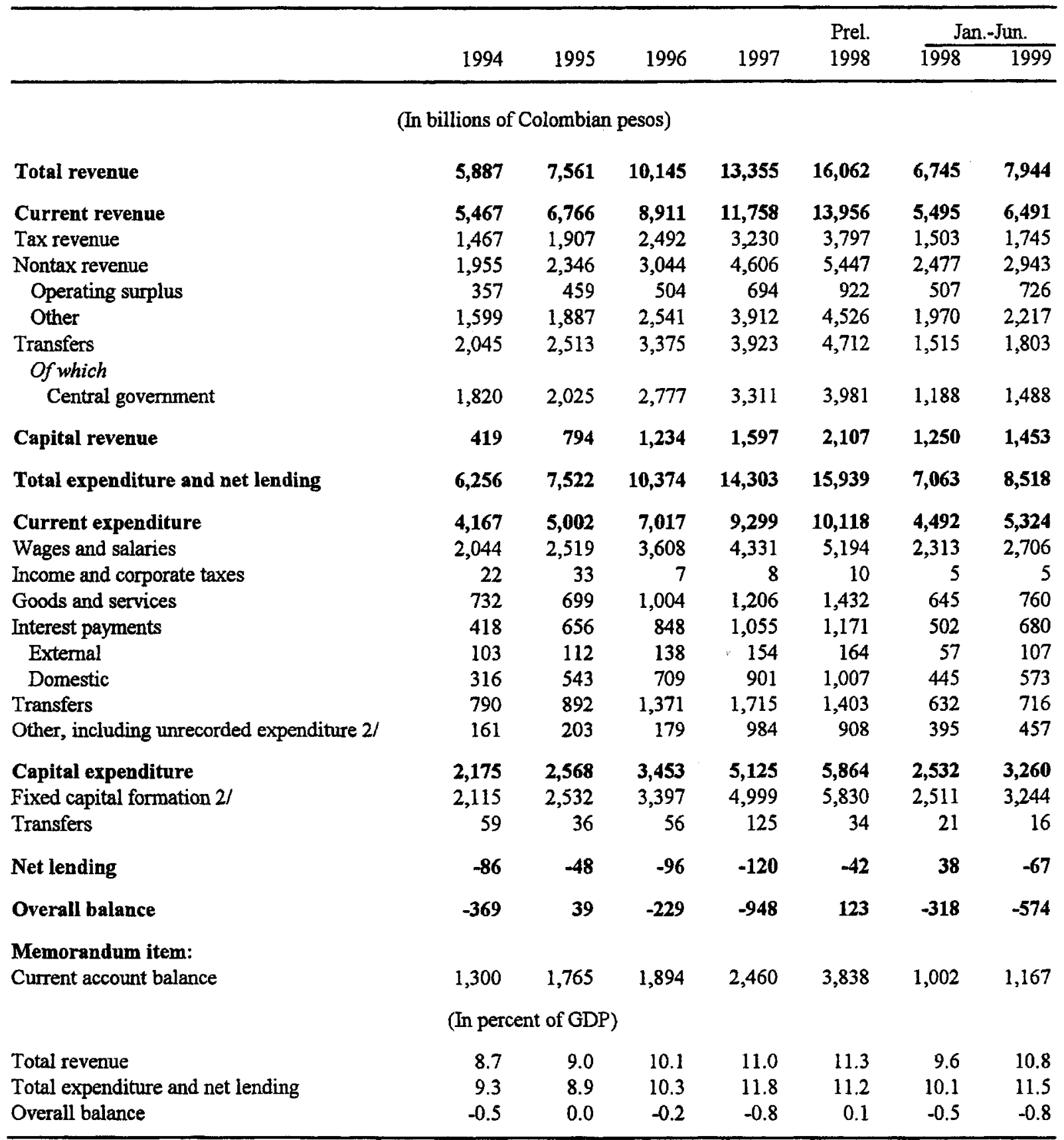

Source: Ministry of Finance and Public Credit.

1/ Includes local governments (municipalities, departments, and districts) and local nonfinancial enterprises comprising water, telephone, and electricity companies; and Medellin metro system.

2/ Beginning in 1997, local government balance is measured from financing data; and accounts include estimates of unrecorded expenditure. Data for 1997 not fully comparable with earlier periods. 
Table 25. Colombia: Operations of the General Government $1 /$

\begin{tabular}{|c|c|c|c|c|c|c|c|}
\hline & \multirow[b]{2}{*}{1994} & \multirow[b]{2}{*}{1995} & \multirow[b]{2}{*}{1996} & \multirow[b]{2}{*}{1997} & \multirow{2}{*}{$\begin{array}{l}\text { Prel. } \\
1998\end{array}$} & \multicolumn{2}{|c|}{ Jan.-Jun. } \\
\hline & & & & & & $1 \overline{998}$ & 1999 \\
\hline \multicolumn{8}{|c|}{ (In billions of Colombian pesos) } \\
\hline Total revenue & 14,095 & 18,760 & 23,967 & 30,308 & 34,447 & 15,843 & 16,706 \\
\hline Current revenue & 14,004 & 18,634 & 23,421 & 30,208 & 34,229 & 15,778 & 16,669 \\
\hline Tax revenue & 10,276 & 13,570 & 16,941 & 21,275 & 24,498 & 11,788 & 11,824 \\
\hline Nontax revenue & 2,977 & 3,989 & 5,189 & 7,107 & 8,106 & 3,454 & 4,270 \\
\hline Operating surplus & 357 & 459 & 504 & 694 & 922 & 507 & 726 \\
\hline Other & 2,620 & 3,530 & 4,685 & 6,413 & 7,184 & 2,947 & 3,544 \\
\hline Transfers & 752 & 1,075 & 1,291 & 1,826 & 1,625 & 535 & 575 \\
\hline Capital revenue & 90 & 125 & 546 & 100 & 218 & 65 & 37 \\
\hline Total expenditure and net lending & 14,603 & 19,468 & 26,483 & 34,005 & 39,594 & 19,302 & 21,526 \\
\hline Current expenditure & 10,851 & 14,277 & 19,500 & 25,437 & $\mathbf{3 0 , 5 3 7}$ & 14,852 & 16,581 \\
\hline Wages and salaries & 4,049 & 5,017 & 6,625 & 8,117 & 9,922 & 4,517 & 5,138 \\
\hline Goods and services & 2,098 & 2,600 & 3,519 & 4,509 & 4,885 & 2,431 & 2,341 \\
\hline Interest & 892 & 1,310 & 1,981 & 2,573 & 4,062 & 2,255 & 2,622 \\
\hline External & 538 & 635 & 642 & 932 & 1,310 & 628 & 776 \\
\hline Domestic & 354 & 674 & 1,339 & 1,641 & 2,752 & 1,627 & 1,847 \\
\hline Transfers & 3,706 & 5,121 & 7,177 & 9,311 & 11,316 & 5,395 & 6,274 \\
\hline Other local government expenditure & 0 & 0 & 0 & 768 & 0 & 0 & 0 \\
\hline Expenditure from floating debt $2 /$ & 106 & 230 & 197 & 158 & 353 & 255 & 206 \\
\hline Capital expenditure & 3,762 & 5,132 & 6,752 & 8,533 & 8,908 & 4,298 & 4,941 \\
\hline Fixed capital formation & 3,480 & 4,868 & 6,337 & 8,039 & 8,566 & 4,121 & 4,720 \\
\hline Transfers & 281 & 265 & 415 & 494 & 343 & 177 & 221 \\
\hline Net lending & -11 & 59 & 231 & 35 & 148 & 151 & 4 \\
\hline Overall balance & -508 & -709 & $-2,516$ & $-3,696$ & $-5,147$ & $-3,459$ & $-4,820$ \\
\hline \multicolumn{8}{|l|}{ Memorandum item: } \\
\hline Current account balance & 3,153 & 4,357 & 3,921 & 4,771 & 3,692 & 925 & 88 \\
\hline \multicolumn{8}{|c|}{ (In percent of GDP) } \\
\hline Total revenue & 20.9 & 22.2 & 23.8 & 24.9 & 24.2 & 22.6 & 22.6 \\
\hline Total expenditure and net lending & 21.6 & 23.1 & 26.3 & 28.0 & 27.8 & 27.5 & 29.2 \\
\hline Overall balance & -0.8 & -0.8 & -2.5 & -3.0 & -3.6 & -4.9 & -6.5 \\
\hline
\end{tabular}

Source: Ministry of Finance and Public Credit.

1/ Includes central government; and local nonfinancial public sector.

2/ Expenditure on an accrual basis not included in other outlays. 
Table 26. Colombia: Operations of the Consolidated National Enterprises

(In billions of Colombian pesos)

\begin{tabular}{|c|c|c|c|c|c|c|c|}
\hline & \multirow[b]{2}{*}{1994} & \multirow[b]{2}{*}{1995} & \multirow[b]{2}{*}{1996} & \multirow[b]{2}{*}{1997} & \multirow{2}{*}{$\begin{array}{l}\text { Prel. } \\
1998\end{array}$} & \multicolumn{2}{|c|}{ Jan.-Jun. } \\
\hline & & & & & & $\overline{1998}$ & 1999 \\
\hline Total revenue & 3,319 & 4,085 & 5,401 & 5,688 & 5,463 & 2,886 & 3,205 \\
\hline Current revenue & 3,190 & 3,889 & 5,090 & 5,475 & 5,295 & 2,797 & 3,086 \\
\hline Tax revenue & 0 & 0 & 0 & 232 & 207 & 143 & 58 \\
\hline Nontax revenue & 3,182 & 3,865 & 5,062 & 5,224 & 5,055 & 2,638 & 2,995 \\
\hline Operating surplus & 2,774 & 3,195 & 4,252 & 3,861 & 3,717 & 2,190 & 2,195 \\
\hline Other & 409 & 670 & 810 & 1,363 & 1,338 & 447 & 801 \\
\hline Transfers & 8 & 24 & 28 & 19 & 33 & 17 & 33 \\
\hline Capital revenue & 129 & 196 & 311 & 213 & 168 & 89 & 118 \\
\hline Total expenditure and net lending & 2,828 & 4,145 & 5,424 & 6,139 & 5,752 & 1,954 & 2,231 \\
\hline Current expenditure & 1,630 & 2,263 & 2,689 & 2,787 & 3,121 & 1,118 & 1,190 \\
\hline Income and corporation taxes & 78 & 39 & 90 & 362 & 87 & 30 & 37 \\
\hline Employment contributions & 124 & 189 & 225 & 255 & 393 & 149 & 194 \\
\hline Interest & 606 & 634 & 762 & 571 & 626 & 210 & 309 \\
\hline External & 272 & 262 & 388 & 268 & 290 & 92 & 176 \\
\hline Domestic & 334 & 372 & 374 & 303 & 336 & 117 & 133 \\
\hline Transfers & 822 & 1,402 & 1,611 & 1,599 & 2,015 & 729 & 650 \\
\hline Capital expenditure & 1,188 & 1,940 & 2,931 & 3,432 & 2,712 & 942 & 1,148 \\
\hline Fixed capital formation & 992 & 1,794 & 2,237 & 3,055 & 2,479 & 865 & 1,106 \\
\hline Transfers & 196 & 146 & 695 & 377 & 233 & 77 & 42 \\
\hline Net lending & 11 & -59 & -196 & -80 & -81 & -106 & -107 \\
\hline Overall balance & 491 & -60 & -22 & -451 & -289 & 931 & 973 \\
\hline \multicolumn{8}{|l|}{ Memorandum items: } \\
\hline Current account balance & 1,560 & 1,626 & 2,401 & 2,688 & 2,174 & 1,679 & 1,896 \\
\hline Operating surplus & 2,774 & 3,195 & 4,252 & 3,861 & 3,717 & 2,190 & 2,195 \\
\hline Operating revenue $(+)$ & 5,319 & 6,610 & 8,012 & 10,424 & 11,075 & 5,519 & 5,271 \\
\hline Wages and salaries $(-)$ & -451 & -523 & -639 & -809 & -936 & -434 & -374 \\
\hline Goods and services (-) & $-2,095$ & $-2,893$ & $-3,121$ & $-5,753$ & $-6,422$ & $-2,895$ & $-2,702$ \\
\hline
\end{tabular}

Source: Ministry of Finance and Public Credit. 
Table 27. Colombia: Operations of the Consolidated National Enterprises

(In percent of GDP)

\begin{tabular}{|c|c|c|c|c|c|c|c|}
\hline & \multirow[b]{2}{*}{1994} & \multirow[b]{2}{*}{1995} & \multirow[b]{2}{*}{1996} & \multirow[b]{2}{*}{1997} & \multirow{2}{*}{$\begin{array}{l}\text { Prel. } \\
1998\end{array}$} & \multicolumn{2}{|c|}{ Jan.-Jun. 1/ } \\
\hline & & & & & & 1998 & 1999 \\
\hline Total revenue & 4.9 & 4.8 & 5.4 & 4.7 & 3.8 & 4.1 & 4.3 \\
\hline Current revenue & 4.7 & 4.6 & 5.1 & 4.5 & 3.7 & 4.0 & 4.2 \\
\hline Tax revenue & 0.0 & 0.0 & 0.0 & 0.2 & 0.1 & 0.2 & 0.1 \\
\hline Nontax revenue & 4.7 & 4.6 & 5.0 & 4.3 & 3.5 & 3.8 & 4.1 \\
\hline Operating surplus & 4.1 & 3.8 & 4.2 & 3.2 & 2.6 & 3.1 & 3.0 \\
\hline Other & 0.6 & 0.8 & 0.8 & 1.1 & 0.9 & 0.6 & 1.1 \\
\hline Transfers & 0.0 & 0.0 & 0.0 & 0.0 & 0.0 & 0.0 & 0.0 \\
\hline Capital revenue & 0.2 & 0.2 & 0.3 & 0.2 & 0.1 & 0.1 & 0.2 \\
\hline Total expenditure and net lending & 4.2 & 4.9 & 5.4 & $\mathbf{5 . 0}$ & 4.0 & 2.8 & $\mathbf{3 . 0}$ \\
\hline Current expenditure & 2.4 & 2.7 & 2.7 & 2.3 & 2.2 & 1.6 & 1.6 \\
\hline Income and corporation taxes & 0.1 & 0.0 & 0.1 & 0.3 & 0.1 & 0.0 & 0.0 \\
\hline Employment contributions & 0.2 & 0.2 & 0.2 & 0.2 & 0.3 & 0.2 & 0.3 \\
\hline Interest & 0.9 & 0.8 & 0.8 & 0.5 & 0.4 & 0.3 & 0.4 \\
\hline External & 0.4 & 0.3 & 0.4 & 0.2 & 0.2 & 0.1 & 0.2 \\
\hline Domestic & 0.5 & 0.4 & 0.4 & 0.2 & 0.2 & 0.2 & 0.2 \\
\hline Transfers & 1.2 & 1.7 & 1.6 & 1.3 & 1.4 & 1.0 & 0.9 \\
\hline Capital expenditure & 1.8 & 2.3 & 2.9 & 2.8 & 1.9 & 1.3 & 1.6 \\
\hline Fixed capital formation & 1.5 & 2.1 & 2.2 & 2.5 & 1.7 & 1.2 & 1.5 \\
\hline Transfers & 0.3 & 0.2 & 0.7 & 0.3 & 0.2 & 0.1 & 0.1 \\
\hline Net lending & 0.0 & -0.1 & -0.2 & -0.1 & -0.1 & -0.2 & -0.1 \\
\hline Overall balance & 0.7 & -0.1 & 0.0 & -0.4 & -0.2 & 1.3 & 1.3 \\
\hline \multicolumn{8}{|l|}{ Memorandum items: } \\
\hline Current account balance & 2.3 & 1.9 & 2.4 & 2.2 & 1.5 & 2.4 & 2.6 \\
\hline Operating surplus & 4.1 & 3.8 & 4.2 & 3.2 & 2.6 & 3.1 & 3.0 \\
\hline Operating revenue $(+)$ & 7.9 & 7.8 & 8.0 & 8.6 & 7.8 & 7.9 & 7.1 \\
\hline Wages and salaries $(-)$ & -0.7 & -0.6 & -0.6 & -0.7 & -0.7 & -0.6 & -0.5 \\
\hline Goods and services $(-)$ & -3.1 & -3.4 & -3.1 & -4.7 & -4.5 & -4.1 & -3.7 \\
\hline
\end{tabular}

Source: Ministry of Finance and Public Credit.

1/ In percent of estimated GDP of the period. 
Table 28. Colombia: Operations of Selected Nonfinancial Public Enterprises

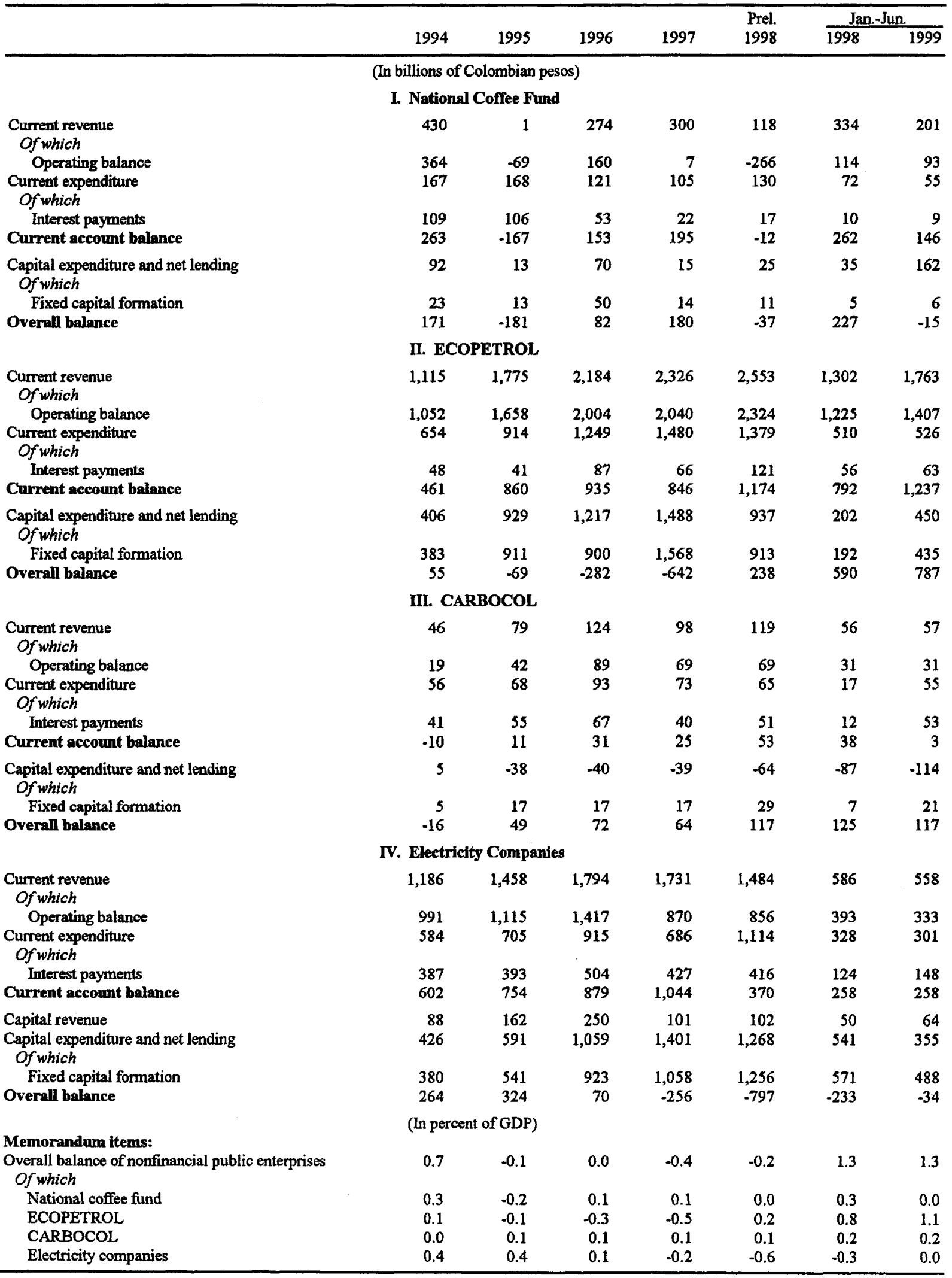

Source: Ministry of Finance and Public Credit. 
Table 29. Colombia: Summary Accounts of the Banco de la Republica (BR)

(End of period stocks; in billions of Colombian pesos)

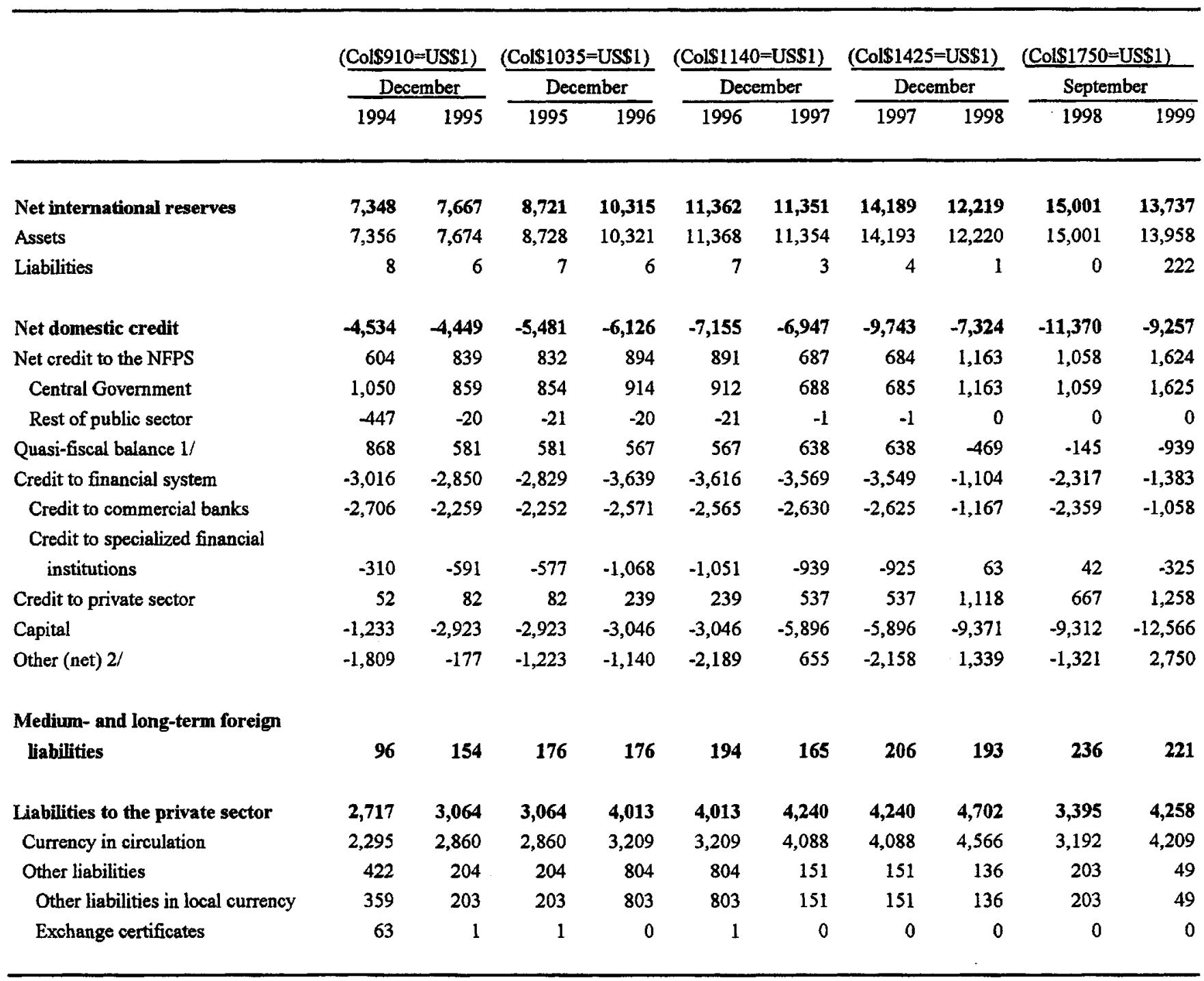

Sources: Banco de la Republica.

1/ As of 1993, estimated on the basis of the profit/loss statement and including cash effects of operations accrued in the previous year and not registered in the bank's profit/loss statement.

2/Inciudes adjustment for exchange rate valuation account, net credit to FOGAFIN, and transfers to the central government of the BR accrued profits. 
Table 30. Colombia: Summary Accounts of the Commercial Banks 1/

(End of period stocks; in billions of Colombian pesos)

\begin{tabular}{|c|c|c|c|c|c|c|c|c|c|c|}
\hline & \multirow{2}{*}{\multicolumn{2}{|c|}{ 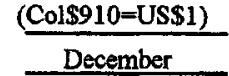 }} & \multirow{2}{*}{\multicolumn{2}{|c|}{$\frac{(\text { Col\$1035=US\$1) }}{\text { December }}$}} & \multirow{2}{*}{\multicolumn{2}{|c|}{$\frac{(\text { Col } \$ 1140=\text { US } \$ 1)}{\text { December }}$}} & \multirow{2}{*}{\multicolumn{2}{|c|}{$\frac{(\text { Col } \$ 1425=\text { US\$1) }}{\text { December }}$}} & \multirow{2}{*}{\multicolumn{2}{|c|}{$\frac{(\text { Col } \$ 1750=\text { US } \$ 1)}{\text { September }}$}} \\
\hline & & & & & & & & & & \\
\hline & 1994 & 1995 & 1995 & 1996 & 1996 & 1997 & 1997 & 1998 & 1998 & 1999 \\
\hline Net short-term foreign assets & $-1,299$ & $-1,640$ & $-1,866$ & $-2,345$ & $-2,583$ & $-2,864$ & $-\mathbf{3 , 5 8 0}$ & $-2,729$ & $-4,441$ & $-2,356$ \\
\hline Assets & 291 & 207 & 235 & 292 & 322 & 581 & 727 & 1,088 & 944 & 695 \\
\hline Liabilities & 1,589 & 1,847 & 2,101 & 2,637 & 2,904 & 3,445 & 4,307 & 3,818 & 5,384 & 3,052 \\
\hline Net domestic assets & 11,408 & 13,680 & 13,920 & 17,666 & 17,916 & 26,360 & 27,163 & 32,449 & 30,489 & 31,833 \\
\hline Monetary authorities & 2,664 & 2,323 & 2,325 & 2,707 & 2,703 & 2,829 & 2,824 & 1,223 & 2,388 & 1,433 \\
\hline Net credit to the NFPS & -528 & -792 & -763 & $-1,258$ & $-1,221$ & -766 & -618 & 1,102 & 153 & 719 \\
\hline Central Government & $-\quad-162$ & -329 & -304 & -276 & -245 & -426 & -289 & 676 & -375 & -114 \\
\hline Rest of public sector & -366 & -462 & -458 & -982 & -977 & -340 & -329 & 427 & 528 & 834 \\
\hline \multicolumn{11}{|l|}{ Net credit to specialized financial } \\
\hline institutions & -646 & -767 & -767 & 83 & 83 & 214 & 214 & $-1,062$ & -368 & $-1,109$ \\
\hline Credit to private sector & 11,452 & 14,956 & 15,292 & 18,636 & 18,936 & 25,795 & 26,517 & 32,869 & 30,517 & 31,409 \\
\hline Capital & $-2,698$ & $-3,531$ & $-3,576$ & $-4,815$ & $-4,836$ & $-6,125$ & $-6,191$ & $-5,169$ & $-6,327$ & $-6,601$ \\
\hline Other (net) $2 /$ & 1,164 & 1,492 & 1,409 & 2,313 & 2,251 & 4,413 & 4,416 & 3,486 & 4,126 & 5,982 \\
\hline \multicolumn{11}{|l|}{ Medium- and long-term foreign } \\
\hline liabilities & 97 & 96 & 110 & 110 & 121 & 335 & 418 & 269 & 301 & 331 \\
\hline Liabilities to the private sector & 10,012 & 11,943 & 11,945 & 15,212 & 15,213 & 23,161 & 23,165 & 29,451 & 25,747 & 29,146 \\
\hline Demand deposits & 2,911 & 3,352 & 3,353 & 4,002 & 4,003 & 4,720 & 4,723 & 4,406 & 3,822 & 3,631 \\
\hline Term and savings deposits & 6,118 & 7,499 & 7,499 & 9,284 & 9,284 & 15,514 & 15,514 & 22,076 & 18,881 & 23,479 \\
\hline Other liabilities & 984 & 1,092 & 1,092 & 1,926 & 1,926 & 2,928 & 2,928 & 2,969 & 3,045 & 2,036 \\
\hline
\end{tabular}

Sources: Banco de la Republica.

$1 /$ Includes the BCH.

2/Includes adjustment for exchange rate valuation account and net credit to FOGAFIN. 
Table 31. Colombia: Summary Accounts of the Specialized Financial Institutions 1/

(End of period stocks; in billions of Colombian pesos)

\begin{tabular}{|c|c|c|c|c|c|c|c|c|c|c|}
\hline & \multirow{2}{*}{\multicolumn{2}{|c|}{$\frac{(\text { Col } \$ 910=\text { US\$1) }}{\text { December }}$}} & \multirow{2}{*}{\multicolumn{2}{|c|}{$\frac{(\text { Col } \$ 1035=\text { US\$ } 1)}{\text { December }}$}} & \multirow{2}{*}{\multicolumn{2}{|c|}{$\frac{(\text { Col\$1140 }=\text { US\$ } 1)}{\text { December }}$}} & \multirow{2}{*}{\multicolumn{2}{|c|}{$\frac{(\text { Col } \$ 1425=\text { US } \$ 1)}{\text { December }}$}} & \multirow{2}{*}{\multicolumn{2}{|c|}{$\frac{(\text { Col } \$ 1750=\text { US } \$ 1)}{\text { September }}$}} \\
\hline & & & & & & & & & & \\
\hline & 1994 & 1995 & 1995 & 1996 & 1996 & 1997 & 1997 & 1998 & 1998 & 1999 \\
\hline Net short-term foreign assets & $-1,174$ & $-1,171$ & $-1,332$ & $-1,475$ & $-1,624$ & $-1,501$ & $-1,876$ & $-1,601$ & $-1,912$ & $-1,068$ \\
\hline Assets & 154 & 122 & 138 & 266 & 294 & 227 & 284 & 231 & 256 & 336 \\
\hline Liabilities & 1,328 & 1,293 & 1,470 & 1,741 & 1,918 & 1,729 & 2,161 & 1,832 & 2,168 & 1,404 \\
\hline Net domestic assets & $\mathbf{1 2 , 5 8 5}$ & 16,300 & 16,718 & 22,171 & 22,589 & 22,273 & 23,309 & 20,579 & 24,871 & 20,981 \\
\hline Monetary authorities & 287 & 632 & 616 & 1,007 & 992 & 767 & 757 & -48 & 110 & 199 \\
\hline Net credit to the NFPS & 1,090 & 985 & 1,181 & 1,616 & 1,800 & 1,592 & 1,993 & 3,044 & 2,433 & 3,790 \\
\hline Central Government & -12 & -61 & -60 & 8 & 10 & 31 & 38 & 649 & 2 & 1,114 \\
\hline Rest of public sector & 1,103 & 1,046 & 1,241 & 1,608 & 1,791 & 1,561 & 1,955 & 2,395 & 2,431 & 2,675 \\
\hline Net credit to commercial banks & 646 & 767 & 767 & -83 & -83 & -214 & -214 & 1,062 & 368 & 1,109 \\
\hline Credit to the private sector & 10,287 & 13,867 & 14,048 & 18,012 & 18,205 & 19,196 & 19,702 & 17,377 & 22,115 & 17,892 \\
\hline Capital & $-2,979$ & $-4,032$ & $-4,037$ & $-5,218$ & $-5,228$ & $-5,996$ & $-6,013$ & $-5,914$ & $-6,522$ & $-6,157$ \\
\hline Other assets (net) $2 /$ & 3,253 & 4,080 & 4,143 & 6,837 & 6,903 & 6,928 & 7,084 & 5,057 & 6,367 & 4,148 \\
\hline \multicolumn{11}{|l|}{ Medium- and long-term } \\
\hline foreign liabilities & 1,679 & 1,871 & 2,128 & 2,649 & 2,917 & 2,642 & 3,303 & 2,945 & 3,876 & 3,481 \\
\hline Liabilities to the private sector & 9,732 & 13,258 & 13,258 & 18,048 & 18,048 & 18,130 & 18,130 & 16,033 & 19,084 & 16,432 \\
\hline Term and savings deposits & 118 & 100 & 100 & 102 & 102 & 9 & 9 & 0 & 0 & 0 \\
\hline Other liabilities & 9,614 & 13,158 & 13,158 & 17,946 & 17,946 & 18,121 & 18,121 & 16,033 & 19,084 & 16,432 \\
\hline
\end{tabular}

Sources: Banco de la Republica.

1/ Comprises development finance corporations, commercial finance companies, savings and loan institutions, cooperative institutions, and development banks (BANCOLDEX, FINAGRO, FINDETER). Excludes FOGAFIN.

2 / Includes adjustment for exchange rate valuation account and net credit to FOGAFIN. 
Table 32. Colombia: Summary Accounts of the Financial System

(End of period stocks; in billions of Colombian pesos)

\begin{tabular}{|c|c|c|c|c|c|c|c|c|c|c|}
\hline & \multirow{2}{*}{\multicolumn{2}{|c|}{$\frac{(\text { Col } \$ 910=\mathrm{US} \$ 1)}{\text { December }}$}} & \multirow{2}{*}{\multicolumn{2}{|c|}{$\frac{(\text { Col\$1035 }=\text { US\$1 })}{\text { December }}$}} & \multirow{2}{*}{\multicolumn{2}{|c|}{$\frac{(\text { Col } \$ 1140=\text { US } \$ 1)}{\text { December }}$}} & \multirow{2}{*}{\multicolumn{2}{|c|}{$\frac{(\text { Col } \$ 1425=\text { US\$1) }}{\text { December }}$}} & \multirow{2}{*}{\multicolumn{2}{|c|}{$\begin{array}{c}\text { (Col\$1750=US\$1) } \\
\text { September }\end{array}$}} \\
\hline & & & & & & & & & & \\
\hline & 1994 & 1995 & 1995 & 1996 & 1996 & 1997 & 1997 & 1998 & 1998 & 1999 \\
\hline Net foreign assets & 4,875 & 4,856 & $\mathbf{5 , 5 2 3}$ & 6,496 & 7,155 & 6,986 & 8,733 & 7,888 & 8,649 & 10,313 \\
\hline Assets & 7,800 & 8,002 & 9,102 & 10,880 & 11,984 & 12,163 & 15,204 & 13,539 & 16,201 & 14,990 \\
\hline Liabilities & 2,925 & 3,146 & 3,578 & 4,384 & 4,829 & 5,177 & 6,471 & 5,651 & 7,552 & 4,677 \\
\hline Net domestic assets & 19,362 & 25,435 & 25,048 & 33,602 & 33,230 & 41,352 & 40,311 & 45,435 & 43,690 & 43,226 \\
\hline Net credit to the NFPS & 1,166 & 1,033 & 1,250 & 1,252 & 1,470 & 1,513 & 2,060 & 5,309 & 3,644 & 6,133 \\
\hline Central Government & 876 & 468 & 489 & 646 & 677 & 293 & 434 & 2,488 & 686 & 2,625 \\
\hline Rest of public sector & 290 & 564 & 761 & 605 & 793 & 1,220 & 1,626 & 2,821 & 2,958 & 3,509 \\
\hline Quasi-fiscal balance & 868 & 581 & 581 & 567 & 567 & 638 & 638 & -469 & -145 & -939 \\
\hline Credit to private sector & 21,792 & 28,904 & 29,422 & 36,887 & 37,380 & 45,528 & 46,757 & 51,364 & 53,299 & 50,559 \\
\hline Capital (-) & $-6,910$ & $-10,486$ & $-10,536$ & $-13,079$ & $-13,110$ & $-18,016$ & $-18,099$ & $-20,454$ & $-22,161$ & $-25,324$ \\
\hline BR capital & $-1,233$ & $-2,923$ & $-2,923$ & $-3,046$ & $-3,046$ & $-5,896$ & $-5,896$ & $-9,371$ & $-9,312$ & $-12,566$ \\
\hline Other capital and surplus & $-5,677$ & $-7,563$ & $-7,613$ & $-10,033$ & $-10,064$ & $-12,121$ & $-12,204$ & $-11,083$ & $-12,848$ & $-12,758$ \\
\hline Other assets (net) $1 /$ & 2,445 & 5,403 & 4,331 & 7,975 & 6,924 & 11,689 & 8,955 & 9,685 & 9,051 & 12,797 \\
\hline \multicolumn{11}{|l|}{ Medium- and long-term } \\
\hline foreign liabilities & 1,775 & 2,025 & 2,304 & 2,825 & $\mathbf{3 , 1 1 1}$ & 2,807 & 3,509 & 3,138 & 4,112 & 3,703 \\
\hline Liabilities to the private sector & $22,461.6$ & $28,266.0$ & $28,267.3$ & $\mathbf{3 7 , 2 7 2 . 7}$ & $37,273.6$ & $45,531.0$ & $45,534.3$ & $\mathbf{5 0 , 1 8 5 . 7}$ & $48,226.1$ & $49,836.0$ \\
\hline Broad money (M3+bonds) & $22,013.9$ & $28,033.8$ & $28,035.1$ & $36,437.2$ & $36,438.1$ & $45,346.4$ & $45,349.7$ & $50,011.3$ & $47,979.6$ & $49,764.0$ \\
\hline M3 & $20,764.6$ & $26,158.5$ & $26,159.8$ & $31,342.1$ & $31,343.0$ & $38,996.7$ & $39,000.0$ & $44,208.3$ & $41,497.2$ & $45,244.2$ \\
\hline Money (M1) & $5,323.8$ & $6,312.1$ & $6,313.4$ & $7,312.6$ & $7,313.5$ & $8,816.7$ & $8,820.0$ & $8,972.0$ & $7,013.6$ & $7,839.8$ \\
\hline Currency in circulation & 2,295 & 2,860 & 2,860 & 3,209 & 3,209 & 4,088 & 4,088 & 4,566 & 3,192 & 4,209 \\
\hline Demand deposits & 3,029 & 3,452 & 3,453 & 4,103 & 4,104 & 4,729 & 4,732 & 4,406 & 3,822 & 3,631 \\
\hline Quasi-money and other & 15,441 & 19,846 & 19,846 & 24,030 & 24,030 & 30,180 & 30,180 & 35,236 & 34,484 & 37,404 \\
\hline Bonds & 1,249 & 1,875 & 1,875 & 5,095 & 5,095 & 6,350 & 6,350 & 5,803 & 6,482 & 4,520 \\
\hline Other liabilities & 448 & 232 & 232 & 835 & 835 & 185 & 185 & 174 & 246 & 72 \\
\hline
\end{tabular}

Sources: Banco de la Republica.

1/ Includes adjustment for exchange rate valuation account, net credit to FOGAFIN, and transfers to the central government of the BR accrued profits. 
Table 33. Colombia: Summary Accounts of the Banco de la Republica (Percentage change) $1 /$

\begin{tabular}{|c|c|c|c|c|c|}
\hline & 1995 & 1996 & 1997 & 1998 & $\begin{array}{r}\text { Sep. } \\
1999\end{array}$ \\
\hline Net international reserves & 11.8 & 52.0 & -0.3 & -46.5 & -37.2 \\
\hline Assets & 11.7 & 52.0 & -0.3 & -46.5 & -30.7 \\
\hline Liabilities & -0.1 & 0.0 & -0.1 & -0.1 & 6.5 \\
\hline Net domestic credit & 3.2 & -21.1 & 5.2 & $\mathbf{5 7 . 1}$ & 62.2 \\
\hline Net credit to the NFPS & 8.7 & 2.0 & -5.1 & 11.3 & 16.7 \\
\hline Central Government & -7.0 & 2.0 & -5.6 & 11.3 & 16.7 \\
\hline Rest of public sector & 15.7 & 0.0 & 0.5 & 0.0 & 0.0 \\
\hline Quasi-fiscal balance $2 /$ & -10.6 & -0.4 & 1.8 & -26.1 & -23.4 \\
\hline Credit to financial system & 6.1 & -26.4 & 1.2 & 57.7 & 27.5 \\
\hline Credit to commercial banks & 16.5 & -10.4 & -1.6 & 34.4 & 38.3 \\
\hline \multicolumn{6}{|l|}{ Credit to specialized financial } \\
\hline Credit to private sector & 1.1 & 5.1 & 7.4 & 13.7 & 17.4 \\
\hline Capital & -62.2 & -4.0 & -71.0 & -82.0 & -95.8 \\
\hline Other (net) $3 /$ & 60.1 & 2.7 & 70.9 & 82.5 & 119.9 \\
\hline Of which: Transfers of accrued profits & -4.1 & 6.2 & 2.5 & 2.0 & 36.6 \\
\hline \multicolumn{6}{|l|}{ Medium- and long-term foreign } \\
\hline liabilities & 2.1 & 0.0 & -0.7 & -0.3 & -0.4 \\
\hline Liabilities to the private sector & 12.8 & $\mathbf{3 1 . 0}$ & 5.6 & 10.9 & 25.4 \\
\hline Currency in circulation & 20.8 & 11.4 & 21.9 & 11.3 & 30.0 \\
\hline Other liabilities & -8.0 & 19.6 & -16.3 & -0.4 & -4.5 \\
\hline Other liabilities in local currency & -5.7 & 19.6 & -16.3 & -0.4 & -4.5 \\
\hline Exchange certificates & -2.3 & 0.0 & 0.0 & 0.0 & 0.0 \\
\hline
\end{tabular}

Sources: Banco de la Republica.

1/ In relation to the stock of liabilities of the Banco de la Republica to the private sector at the beginning of the period.

2/ As of 1993, estimated on the basis of the profit/loss statement and including cash effects of operations accrued in the previous year and not registered in the bank's profit/loss statement.

3/ Includes adjustment for exchange rate valuation account, net credit to FOGAFIN, and transfers to the central government of the BR accrued profits. 
Table 34. Colombia: Summary Accounts of the Financial System (Percentage change) $1 /$

\begin{tabular}{|c|c|c|c|c|c|}
\hline & 1995 & 1996 & 1997 & 1998 & $\begin{array}{r}\text { Sep. } \\
1999\end{array}$ \\
\hline Net foreign assets & -0.1 & 3.4 & -0.5 & -1.9 & 3.5 \\
\hline Assets & 0.9 & 6.3 & 0.5 & -3.7 & -2.5 \\
\hline Liabilities & 1.0 & 2.9 & 0.9 & -1.8 & -6.0 \\
\hline Net domestic assets & 27.0 & 30.3 & 21.8 & 11.3 & -1.0 \\
\hline Net credit to the NFPS & -0.6 & 0.0 & 0.1 & 7.1 & 5.2 \\
\hline Central Government & -1.8 & 0.6 & -1.0 & 4.5 & 4.0 \\
\hline Rest of public sector & 1.2 & -0.6 & 1.1 & 2.6 & 1.1 \\
\hline Quasi-fiscal balance & -1.3 & 0.0 & 0.2 & -2.4 & -1.6 \\
\hline Credit to private sector & 31.7 & 26.4 & 21.9 & 10.1 & -5.7 \\
\hline Capital (-) & -15.9 & -9.0 & -13.2 & -5.2 & -6.6 \\
\hline BR capital & -7.5 & -0.4 & -7.6 & -7.6 & -6.7 \\
\hline Other capital and surplus & -8.4 & -8.6 & -5.5 & 2.5 & 0.2 \\
\hline Other assets (net) $2 /$ & 13.2 & 12.9 & 12.8 & 1.6 & 7.8 \\
\hline \multicolumn{6}{|l|}{ Medium- and long-term } \\
\hline foreign liabilities & 1.1 & 1.8 & -0.8 & -0.8 & -0.8 \\
\hline Liabilities to the private sector & 25.8 & 31.9 & 22.2 & 10.2 & 3.3 \\
\hline Broad money (M3+bonds) & 26.8 & 29.7 & 23.9 & 10.2 & 3.7 \\
\hline M3 & 24.0 & 18.3 & 20.5 & 11.4 & 7.8 \\
\hline Money (M1) & 4.4 & 3.5 & 4.0 & 0.3 & 1.7 \\
\hline Currency in circulation & 2.5 & 1.2 & 2.4 & 1.0 & 2.1 \\
\hline Demand deposits & 1.9 & 2.3 & 1.7 & -0.7 & -0.4 \\
\hline Quasi-money and other & 19.6 & 14.8 & 16.5 & 11.1 & 6.1 \\
\hline Bonds & 2.8 & 11.4 & 3.4 & -1.2 & -4.1 \\
\hline Other liabilities & -1.0 & 2.1 & -1.7 & 0.0 & -0.4 \\
\hline
\end{tabular}

Sources: Banco de la Republica.

1/In relation to the stock of liabilities of the Financial System to the private sector at the beginning of the period.

2/ Includes adjustment for exchange rate valuation account, net credit to FOGAFIN, and transfers to the central government of the BR accrued profits. 
Table 35. Colombia: Financial Indicators

\begin{tabular}{|c|c|c|c|c|c|c|c|c|c|c|}
\hline & & & & \multicolumn{7}{|c|}{ Monetary and Credit Aggregates 1/ } \\
\hline & \multicolumn{3}{|c|}{$\begin{array}{l}\text { Open Market Operations: Stock of } \\
\text { Central Bank Paper at End of Period }\end{array}$} & \multirow[b]{2}{*}{$\begin{array}{l}\text { Currency in } \\
\text { Circulation }\end{array}$} & \multicolumn{2}{|c|}{ M1 2/ } & \multicolumn{2}{|c|}{$\mathrm{M} 3 * 3 /$} & \multicolumn{2}{|c|}{$\begin{array}{c}\text { Credit to } \\
\text { Private Sector } \\
\end{array}$} \\
\hline & $\begin{array}{c}\text { Open Market } \\
\text { Bills }\end{array}$ & $\begin{array}{r}\text { Exchange } \\
\text { Certificates } \\
\end{array}$ & Total & & Sectorized & $\begin{array}{l}\begin{array}{l}\text { Non- } \\
\text { sectorized }\end{array} \\
\end{array}$ & Sectorized & $\begin{array}{l}\text { Non- } \\
\text { sectorized }\end{array}$ & Sectorized & $\begin{array}{l}\text { Non- } \\
\text { sectorized }\end{array}$ \\
\hline & \multicolumn{3}{|c|}{ (In billions of Colombia pesos) } & \multicolumn{7}{|c|}{ (Percentage change) } \\
\hline \multicolumn{11}{|l|}{1994} \\
\hline December & 994.2 & 59.0 & $1,053.2$ & 29.8 & 23.7 & 25.3 & 42.7 & 43.6 & 40.4 & 44.9 \\
\hline \multicolumn{11}{|l|}{1995} \\
\hline December & 216.1 & 1.1 & 217.2 & 26.6 & 19.6 & 20.2 & 27.2 & 29.3 & 35.7 & 36.2 \\
\hline \multicolumn{11}{|l|}{1996} \\
\hline December & $1,263.1$ & 0.8 & $1,263.9$ & 12.9 & 16.4 & 16.5 & 30.4 & 29.9 & 25.3 & 26.0 \\
\hline \multicolumn{11}{|l|}{1997} \\
\hline March & $2,043.8$ & 0.8 & $2,044.6$ & 23.3 & 16.4 & 14.9 & 25.9 & 25.6 & 17.5 & 23.6 \\
\hline June & $1,951.2$ & 0.7 & $1,951.9$ & 25.1 & 20.9 & 22.5 & 25.1 & 27.4 & 17.8 & 21.8 \\
\hline September & $1,978.0$ & 0.6 & $1,978.6$ & 25.7 & 23.3 & 20.4 & 26.3 & 26.4 & 21.1 & 22.0 \\
\hline December & 53.8 & 0.5 & 54.3 & 26.6 & 22.2 & 21.7 & 24.6 & 26.7 & 25.0 & 27.0 \\
\hline \multicolumn{11}{|l|}{1998} \\
\hline January & 323.0 & 0.6 & 323.6 & 26.4 & 15.2 & 22.6 & 25.5 & 26.1 & 26.7 & 28.1 \\
\hline February & 203.9 & 0.6 & 204.5 & 25.6 & 24.0 & 17.3 & 28.4 & 26.6 & 25.5 & 29.1 \\
\hline March & 2.1 & 0.6 & 2.7 & 14.8 & 15.9 & 12.2 & 25.2 & 27.0 & 25.7 & 28.9 \\
\hline April & 8.6 & 0.6 & 9.2 & 18.5 & 19.0 & 8.0 & 25.4 & 24.7 & 27.1 & 29.2 \\
\hline May & 1.1 & 0.6 & 1.7 & 16.5 & 14.4 & 9.3 & 25.0 & 26.0 & 27.3 & 30.8 \\
\hline June & 0.4 & 0.6 & 1.0 & 11.8 & 9.6 & 2.2 & 23.1 & 23.1 & 24.8 & 27.8 \\
\hline July & 156.4 & 0.6 & 157.0 & 9.2 & 11.6 & 2.5 & 21.5 & 21.0 & 23.3 & 25.6 \\
\hline August & 3.2 & 0.6 & 3.8 & 10.5 & 13.0 & 4.7 & 20.8 & 21.0 & 22.3 & 24.9 \\
\hline September & 41.6 & 0.6 & 42.2 & 18.3 & 9.1 & 0.9 & 19.1 & 16.3 & 21.2 & 22.6 \\
\hline October & 118.7 & 0.6 & 119.3 & 7.3 & 4.1 & -3.3 & 16.6 & 13.4 & 18.5 & 19.5 \\
\hline November & 39.6 & 0.6 & 40.2 & 7.1 & 5.2 & -4.5 & 12.4 & 10.5 & 17.2 & 16.4 \\
\hline December & 25.8 & 0.5 & 26.3 & 12.1 & 1.9 & -3.9 & 10.2 & 7.9 & 12.8 & 12.6 \\
\hline \multicolumn{11}{|l|}{1999} \\
\hline January & 0 & 0.6 & 0.6 & 12.1 & 5.4 & -1.7 & 11.7 & 8.9 & 12.1 & 11.0 \\
\hline February & 0 & 0.6 & 0.6 & 12.0 & 3.2 & -1.4 & 10.5 & 9.5 & 9.7 & 7.9 \\
\hline March & 0 & 0.6 & 0.6 & 20.2 & 2.3 & -1.7 & 11.0 & 7.0 & 8.0 & 5.2 \\
\hline April & 0 & 0.6 & 0.6 & 11.6 & 3.7 & 1.0 & 7.1 & 7.5 & 4.7 & 3.1 \\
\hline May & 0 & 0.6 & 0.6 & 16.1 & 5.9 & 3.2 & 6.4 & 5.1 & 3.1 & 1.6 \\
\hline June & 0 & 0.6 & 0.6 & 29.5 & 8.7 & 6.3 & 5.9 & 5.0 & 3.8 & 2.0 \\
\hline July & 0 & 0.6 & 0.6 & 27.4 & 17.1 & 11.1 & 4.6 & 3.8 & 1.8 & 2.1 \\
\hline August & 0 & 0.6 & 0.6 & 29.0 & 11.3 & 9.0 & 5.0 & 3.7 & -0.6 & 0.6 \\
\hline September & 0 & 0.6 & 0.6 & 28.2 & 11.6 & 11.3 & 3.5 & 4.6 & -1.5 & 0.7 \\
\hline
\end{tabular}

Sources: Banco de la Republica.

1/ "Nonsectorized" data may not exclude all assets and liabilities of the nonfinancial public sector from M1, M3, and credit to the private sector.

2/ Currency in circulation plus demand deposits.

3/ Ml + quasi-money + fiduciary deposits + bank acceptances + bonds issued by financial institutions. 
Table 36. Colombia: Interest Rates

(In percent)

\begin{tabular}{|c|c|c|c|c|c|c|c|c|c|}
\hline & \multirow{2}{*}{$\begin{array}{l}\text { Central Bank } \\
\text { Discount rate } \\
\text { (End of period) }\end{array}$} & \multicolumn{7}{|c|}{ Financial System } & \multirow{2}{*}{$\begin{array}{l}\text { Treasury } \\
\text { Bill Rate } \\
\text { (1-year) }\end{array}$} \\
\hline & & $\begin{array}{l}\text { Deposit } \\
\text { 90-Days }\end{array}$ & $\begin{array}{l}t \text { rates by mat } \\
180 \text {-Days } 3\end{array}$ & $\begin{array}{l}\text { turity } \\
\text { 360-Days }\end{array}$ & Interbank & $\begin{array}{l}\text { Deposit } \\
\text { Rate } 1 /\end{array}$ & $\begin{array}{c}\text { Lending } \\
\text { Rate } 2\end{array}$ & Spread & \\
\hline \multicolumn{10}{|l|}{1994} \\
\hline December & 44.9 & 37.9 & 39.4 & 35.2 & $\ldots$ & 37.9 & 46.6 & 6.3 & $\cdots$ \\
\hline \multicolumn{10}{|l|}{1995} \\
\hline December & 40.4 & 33.4 & 34.3 & 34.4 & $\cdots$ & 33.4 & 44.2 & 8.1 & $\ldots$ \\
\hline \multicolumn{10}{|l|}{1996} \\
\hline December & 35.1 & 28.1 & 29.6 & 30.3 & 23.5 & 28.1 & 38.7 & 8.3 & $\cdots$ \\
\hline \multicolumn{10}{|l|}{1997} \\
\hline March & 32.5 & 25.5 & 26.1 & 26.3 & 26.8 & 25.5 & 36.1 & 8.4 & 25.3 \\
\hline June & 30.2 & 23.2 & 23.9 & 24.3 & 23.2 & 23.2 & 33.8 & 8.6 & 23.8 \\
\hline September & 29.9 & 22.9 & 23.7 & 24.4 & 22.7 & 22.9 & 32.7 & 8.0 & 23.0 \\
\hline December & 31.3 & 24.3 & 24.9 & 25.4 & 25.4 & 24.3 & 33.2 & 7.1 & 23.3 \\
\hline \multicolumn{10}{|l|}{1998} \\
\hline January & 31.6 & 24.6 & 25.0 & 25.3 & 26.4 & 24.6 & 34.2 & 7.7 & 23.8 \\
\hline February & 32.0 & 25.0 & 25.6 & 25.1 & 28.9 & 25.0 & 34.5 & 7.6 & 28.5 \\
\hline March & 35.0 & 28.0 & 27.9 & 27.8 & 32.3 & 28.0 & 37.2 & 7.2 & 28.8 \\
\hline April & 37.7 & 30.7 & 30.2 & 30.2 & 35.9 & 30.7 & 40.2 & 7.3 & 31.0 \\
\hline May & 38.7 & 31.7 & 31.4 & 32.0 & 31.8 & 31.7 & 40.0 & 6.3 & 31.5 \\
\hline June & 43.6 & 36.6 & 34.2 & 33.6 & 50.8 & 36.6 & 50.5 & 10.2 & $\ldots$ \\
\hline July & 43.4 & 36.4 & 35.6 & 35.8 & 36.4 & 36.4 & 43.8 & 5.4 & 33.9 \\
\hline August & 41.2 & 34.2 & 34.3 & 34.1 & 34.2 & 34.2 & 41.2 & 5.2 & 32.5 \\
\hline September & 42.6 & 35.6 & 36.1 & 33.7 & 43.6 & 35.6 & 47.2 & 8.6 & 35.0 \\
\hline October & 43.5 & 36.5 & 36.8 & 34.3 & 37.6 & 36.5 & 47.2 & 7.8 & $\ldots$ \\
\hline November & 43.4 & 36.4 & 37.0 & 34.6 & 33.4 & 36.4 & 45.9 & 7.0 & 34.9 \\
\hline December & 42.3 & 35.3 & 35.8 & 34.8 & 28.8 & 35.3 & 44.5 & 6.8 & 32.5 \\
\hline \multicolumn{10}{|l|}{1999} \\
\hline January & 40.2 & 33.2 & 33.0 & 32.5 & 27.0 & 33.2 & 42.3 & 6.8 & 30.6 \\
\hline February & 37.3 & 30.3 & 31.0 & 30.3 & 23.1 & 30.3 & 38.3 & 6.2 & 26.2 \\
\hline March & 32.3 & 25.3 & 26.4 & 27.3 & 22.1 & 25.3 & 35.9 & 8.4 & 22.3 \\
\hline April & 29.1 & 22.1 & 23.7 & 23.8 & 20.7 & 22.1 & 32.8 & 8.8 & 17.9 \\
\hline May & 26.0 & 19.0 & 20.3 & 20.2 & 18.9 & 19.0 & 29.3 & 8.6 & 16.5 \\
\hline June & 24.9 & 17.9 & 18.7 & 19.4 & 18.8 & 17.9 & 27.3 & 8.0 & 18.1 \\
\hline July & 26.2 & 19.2 & 19.9 & 20.1 & 21.0 & 19.2 & 27.3 & 6.9 & 20.5 \\
\hline August & 25.9 & 18.9 & 19.9 & 20.4 & 17.6 & 18.9 & 26.1 & 6.1 & 18.2 \\
\hline September & 25.1 & 18.1 & 19.6 & 20.5 & 18.1 & 18.1 & 26.2 & 6.9 & 18.5 \\
\hline
\end{tabular}

Sources: Banco de la Republica.

1/ Average yield on three-month deposits.

2/ Average rates based on survey of financial intermediaries. 
Table 37. Colombia: Requirements for Monetary Reserves, Reserve-Substituting Investments, and Obligatory Investments

(In peroent)

\begin{tabular}{|c|c|c|c|c|c|c|c|c|c|c|c|c|}
\hline & \multirow{2}{*}{\multicolumn{3}{|c|}{$\frac{\text { December } 1996}{\text { Marginal }}$}} & \multicolumn{3}{|c|}{ December 1997} & \multicolumn{3}{|c|}{$\frac{\text { December } 1998}{\text { Marginal }}$} & \multicolumn{3}{|c|}{ November 1999} \\
\hline & & & & \multicolumn{3}{|c|}{ Marginal } & \multicolumn{3}{|c|}{ Marginal } & \multicolumn{3}{|c|}{ Marginal } \\
\hline & $\begin{array}{c}\text { Monetary } \\
\text { Reserve }\end{array}$ & $\begin{array}{l}\text { Monetary } \\
\text { Reserve }\end{array}$ & $\begin{array}{l}\text { Obligatory } \\
\text { Investments }\end{array}$ & $\begin{array}{r}\text { Monetary } \\
\text { Reserve }\end{array}$ & $\begin{array}{c}\text { Monetary } \\
\text { Reserve }\end{array}$ & $\begin{array}{l}\text { Obligatory } \\
\text { Investments }\end{array}$ & $\begin{array}{r}\text { Monetary } \\
\text { Reserve }\end{array}$ & $\begin{array}{r}\text { Monetary } \\
\text { Reserve }\end{array}$ & $\begin{array}{l}\text { Obligatory } \\
\text { Investments }\end{array}$ & $\begin{array}{c}\text { Monetary } \\
\text { Reserve }\end{array}$ & $\begin{array}{r}\text { Monetary } \\
\text { Reserve }\end{array}$ & $\begin{array}{l}\text { Obligatory } \\
\text { Investments }\end{array}$ \\
\hline \multicolumn{13}{|l|}{ Commercial banks } \\
\hline Sight deposits, private 1/ & 21 & 21 & 7 & 21 & 21 & 7 & 16 & 16 & 7 & 13 & 13 & 7 \\
\hline Sight deposits, public 1/ & 21 & 21 & 7 & 21 & 21 & 7 & 16 & 16 & 7 & 13 & 13 & 7 \\
\hline \multicolumn{13}{|l|}{ CDT (time deposits) longer than } \\
\hline 18 months $\mathrm{t} / 2 /$ & 5 & 5 & 7 & 5 & 5 & 7 & 0.5 & 0.5 & 7 & 2.5 & 2.5 & 7 \\
\hline \multicolumn{13}{|l|}{ CDT (time deposits) between } \\
\hline 12 and 18 months $1 / 2 /$ & 5 & 7 & 7 & 5 & 7 & 7 & 0.5 & 0.5 & 7 & 2.5 & 2.5 & 7 \\
\hline CDTs between 6 and 12 months $1 / 2 /$ & 5 & 7 & 7 & 5 & 7 & 7 & 0.5 & 0.5 & 7 & 2.5 & 2.5 & 7 \\
\hline CDTs shorter than 6 months $1 / 2 /$ & 5 & 7 & 7 & 5 & 7 & 7 & 0.5 & 0.5 & 7 & 2.5 & 2.5 & 7 \\
\hline Traditional savings deposits & 10 & 10 & 7 & 10 & 10 & 7 & 5 & 5 & 7 & 6 & 6 & 7 \\
\hline Fiduciary deposits & 21 & 21 & 7 & 21 & 21 & 7 & 16 & 16 & 7 & 13 & 13 & 7 \\
\hline Bonds shorter than 18 months & & 7 & & & 7 & & & 0.5 & & & 2.5 & \\
\hline \multicolumn{13}{|l|}{ Development finance corporations } \\
\hline CDTs longer than 18 months $1 / 2$ J & 5 & 5 & 7 & 5 & 5 & 7 & 0.5 & 0.5 & 7 & 2.5 & 2.5 & 7 \\
\hline CDTs between 12 and 18 months $1 / 2$ & 5 & 7 & 7 & 5 & 7 & 7 & 0.5 & 0.5 & 7 & 2.5 & 2.5 & 7 \\
\hline CDTs between 6 and 12 months $1 / 2 /$ & 5 & 7 & 7 & 5 & 7 & 7 & 0.5 & 0.5 & 7 & 2.5 & 2.5 & 7 \\
\hline CDTs shorter than 6 months $1 / 2$ / & 5 & 7 & 7 & 5 & 7 & 7 & 0.5 & 0.5 & 7 & 2.5 & 2.5 & 7 \\
\hline Traditional savings deposits & 10 & 10 & & 10 & 10 & & 5 & 5 & & 6 & 6 & \\
\hline Bonds shorter than 18 months & & 7 & & & 7 & & 0.5 & 0.5 & & & 2.5 & \\
\hline \multicolumn{13}{|l|}{ Savings and loan institutions } \\
\hline Savings account (UPAC) & 10 & 10 & 1 & 10 & 10 & 1 & 5 & 5 & 1 & 6 & 6 & 1 \\
\hline CDTs 1.6 months (UPAC) & 5 & 7 & 1 & 5 & 7 & 1 & 0.5 & 0.5 & 1 & 2.5 & 2.5 & 1 \\
\hline CDTs 6-12 months (UPAC) & 5 & 7 & 1 & 5 & 7 & 1 & 0.5 & 0.5 & 1 & 2.5 & 2.5 & $\mathbf{1}$ \\
\hline CDTs between 12 and 18 months & 5 & 7 & 1 & 5 & 7 & 1 & 0.5 & 0.5 & 1 & 2.5 & 2.5 & 1 \\
\hline CDTs longer than 18 months & 5 & 5 & 1 & 5 & 5 & 1 & 0.5 & 0.5 & 1 & 2.5 & 2.5 & 1 \\
\hline Nonindexed deposits & 10 & 10 & 1 & 10 & 10 & 1 & 5 & 5 & 1 & 6 & 6 & 1 \\
\hline Bonds shorter than 18 months & $\mathbf{0}$ & 7 & & 0 & 7 & & 0.5 & 0.5 & & & 2.5 & \\
\hline Fiduciary deposits & 21 & 21 & & 21 & 21 & & 16 & 16 & & 13 & 13 & \\
\hline \multicolumn{13}{|l|}{ Commercial finance companies } \\
\hline CDTs longer than 18 months $1 / 2 /$ & 5 & 5 & 7 & 5 & 5 & 7 & 0.5 & 0.5 & 7 & 2.5 & 2.5 & 7 \\
\hline CDTs between 12 and 18 months $1 / 2$ & 5 & 7 & 7 & 5 & 7 & 7 & 0.5 & 0.5 & 7 & 2.5 & 2.5 & 7 \\
\hline CDTs between 6 and 12 months $1 / 2$ & 5 & 7 & 7 & 5 & 7 & 7 & 0.5 & 0.5 & 7 & 2.5 & 2.5 & 7 \\
\hline CDTs shorter than 6 months $1 / 2 /$ & 5 & 7 & 7 & 5 & 7 & 7 & 0.5 & 0.5 & 7 & 2.5 & 2.5 & 7 \\
\hline Bonds shorter than 18 months & & 7 & & & 7 & & & 0.5 & & & 2.5 & \\
\hline
\end{tabular}

Source: Banco de la Republica.

1/ Obligatory refers to a 5 percent obligatory investment in Titulos de Desarrollo Agropecuario Class B and 2 percent in Class A (FINAGRO).

2/ The amount held as of April 16, 1991 in FINAGRO Class $\mathrm{C}$ and other development bonds was to be used permanently to meet reserve-substituting requirements. This allowed for a gradual conversion of requirements from reserve-substituting into monetary as CDT deposits increased. 
Table 38. Colombia: Reserves, Open Market Instruments, and Exchange Certificates (In billions of Colombian pesos at end of period, unless otherwise indicated)

\begin{tabular}{|c|c|c|c|c|c|c|}
\hline & 1994 & 1995 & 1996 & 1997 & 1998 & $\begin{array}{l}\text { Sep. } \\
1999\end{array}$ \\
\hline Monetary reserves & $3,364.4$ & $3,393.8$ & $3,387.5$ & $4,184.8$ & $2,319.6$ & $3,062.0$ \\
\hline \multicolumn{7}{|l|}{ As percent of financial intermediaries } \\
\hline total liabilities $1 /$ & 16.6 & 13.0 & 10.7 & 10.5 & 5.3 & 6.8 \\
\hline As percent of monetary base & 59.7 & 54.2 & 51.1 & 50.5 & 33.5 & 40.8 \\
\hline Open market bills of Banco de la Republica & 994.0 & 216.1 & $1,263.0$ & 53.8 & 25.8 & 18.0 \\
\hline As percent of monetary base & 17.6 & 3.4 & 19.1 & 0.6 & 0.4 & 0.2 \\
\hline Exchange certificates $2 /$ & 59.0 & 1.1 & 0.8 & 0.6 & 0.5 & 0.6 \\
\hline As percent of monetary base & 0 & 0 & 0 & 0 & 0 & 0 \\
\hline \multicolumn{7}{|l|}{ Memorandum item: } \\
\hline Exchange rate, Colombian pesos per U.S. dollar & 829.3 & 986.8 & $1,003.5$ & $1,287.1$ & $1,511.0$ & $2,015.2$ \\
\hline
\end{tabular}

Sources: Banco de la Republica.

1/ Demand, savings, and time deposits with commercial banks, savings and loans, development finance corporations, and commercial finance companies.

2/ U.S. dollar-denominated certificates valued at exchange rate indicated in memorandum item. 
Table 39. Colombia: Sectoral Credit Lines

(In millions of Colombian pesos, end of period)

\begin{tabular}{|c|c|c|c|c|c|c|}
\hline & 1994 & 1995 & 1996 & 1997 & 1998 & $\begin{array}{l}\text { Sept. } \\
1999\end{array}$ \\
\hline \multicolumn{7}{|c|}{ Fondo Financiero Agropecuario (FINAGRO) 1/ } \\
\hline Gross credit & 822,700 & $1,183,000$ & $1,043,431$ & 952,683 & $1,181,770$ & $1,091,158$ \\
\hline Forced investment and other resources & 902,000 & $1,317,600$ & $1,043,431$ & 952,683 & $1,181,770$ & $1,091,158$ \\
\hline Net rediscount of Banco de la Republica & 0 & 0 & 0 & 0 & 0 & 0 \\
\hline \multicolumn{7}{|l|}{ Fondo de Apoyo a la Vivienda (FAVI) } \\
\hline Gross credit & 39,000 & 0 & 0 & 0 & 0 & 0 \\
\hline Forced investment and other resources & 439,000 & 0 & 0 & 0 & 0 & 0 \\
\hline Net rediscount of Banco de la Republica & $-400,000$ & 0 & 0 & 0 & 0 & 0 \\
\hline \multicolumn{7}{|l|}{ BANCOLDEX 2/ } \\
\hline Gross credit & $1,181,300$ & $1,560,000$ & $1,579,159$ & $1,863,597$ & $2,156,464$ & $2,394,782$ \\
\hline Total assets & $1,252,800$ & $1,647,700$ & $1,776,286$ & $2,040,217$ & $2,402,324$ & $2,649,106$ \\
\hline Capital and reserves & 436,500 & 573,700 & 719,600 & 846,700 & $1,010,000$ & $1,093,800$ \\
\hline Banco de la Republica credit (net) & $-6,600$ & $-12,100$ & 0 & 0 & 0 & 0 \\
\hline Other sources of funds & 822,900 & $1,086,100$ & $1,056,686$ & $1,193,517$ & $1,392,324$ & $1,555,306$ \\
\hline \multicolumn{7}{|l|}{ Memorandum items: } \\
\hline Total gross credit & $2,043,000$ & $2,743,000$ & $2,622,590$ & $2,816,281$ & $3,338,234$ & $3,485,940$ \\
\hline As percent of total financial system credit & 8.2 & 8.0 & 6.1 & 5.8 & 6.3 & 6.7 \\
\hline
\end{tabular}

Source: Banco de la Republica.

1/FINAGRO operates outside the Banco de la Republica since 1991.

2/ BANCOLDEX operates outside the Banco de la Republica since 1993 when it succeeded PROEXPO. 
Table 40. Colombia: Lending Rates of Sectoral Credit Funds

(In percent)

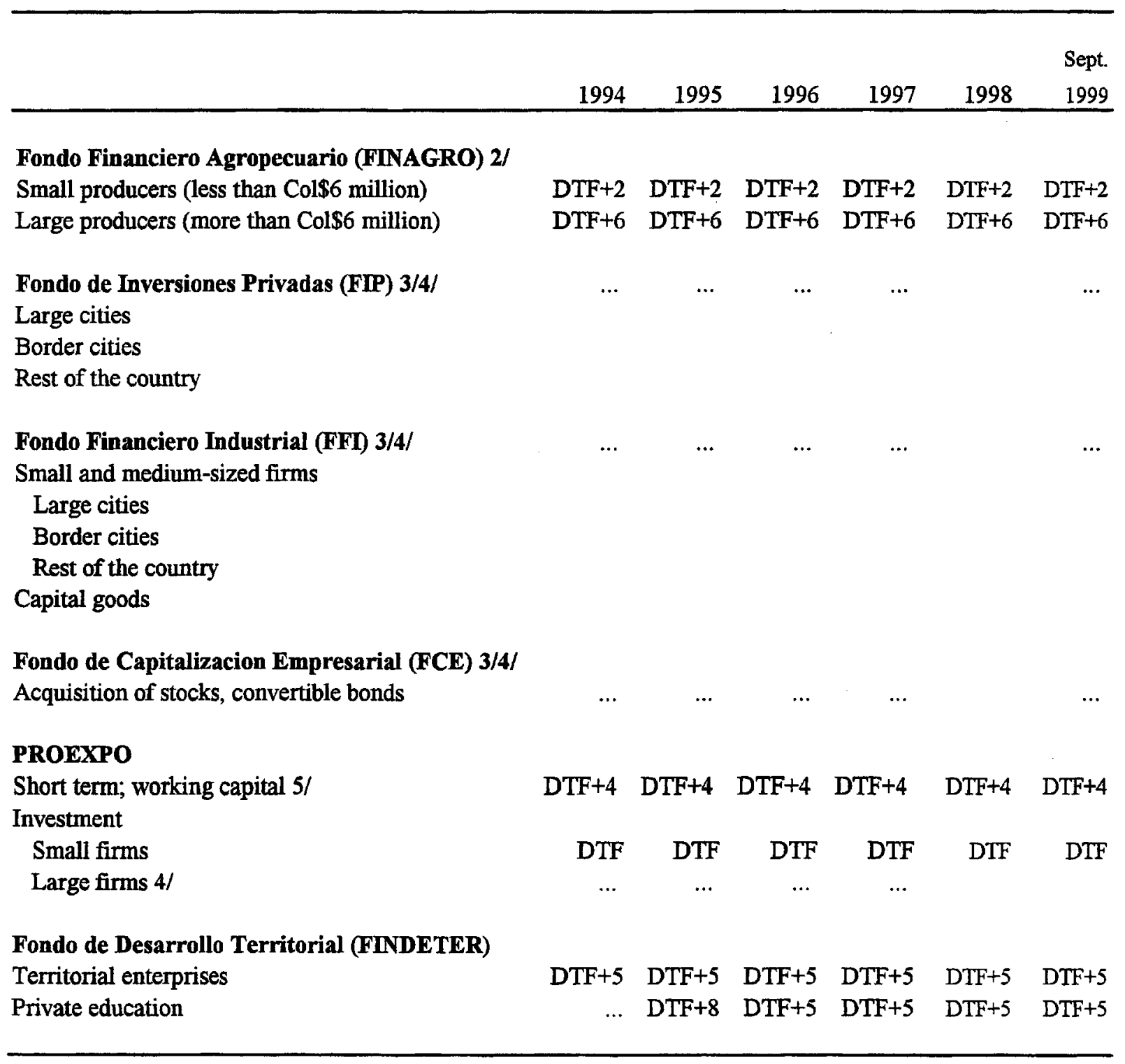

Source: Banco de la Republica.

1/ DTF is the average (effective annual) rate on three-month time deposits in financial system.

2/ FINAGRO operates outside the Banco de la Republica since 1991.

3/ Transferred from the Banco de la Republica to the Industrial Development Institute in 1993.

4/ May be freely set since 1993; not subject to interest rate ceiling.

5/ Short-term preshipment credit in local currency; DTF +4.5 points for medium-term preshipment credit, and six-month LIBOR plus 3.5 points for preshipment credit denominated in U.S. dollars. 
Table 41. Colombia: Forced Investment by Instrument

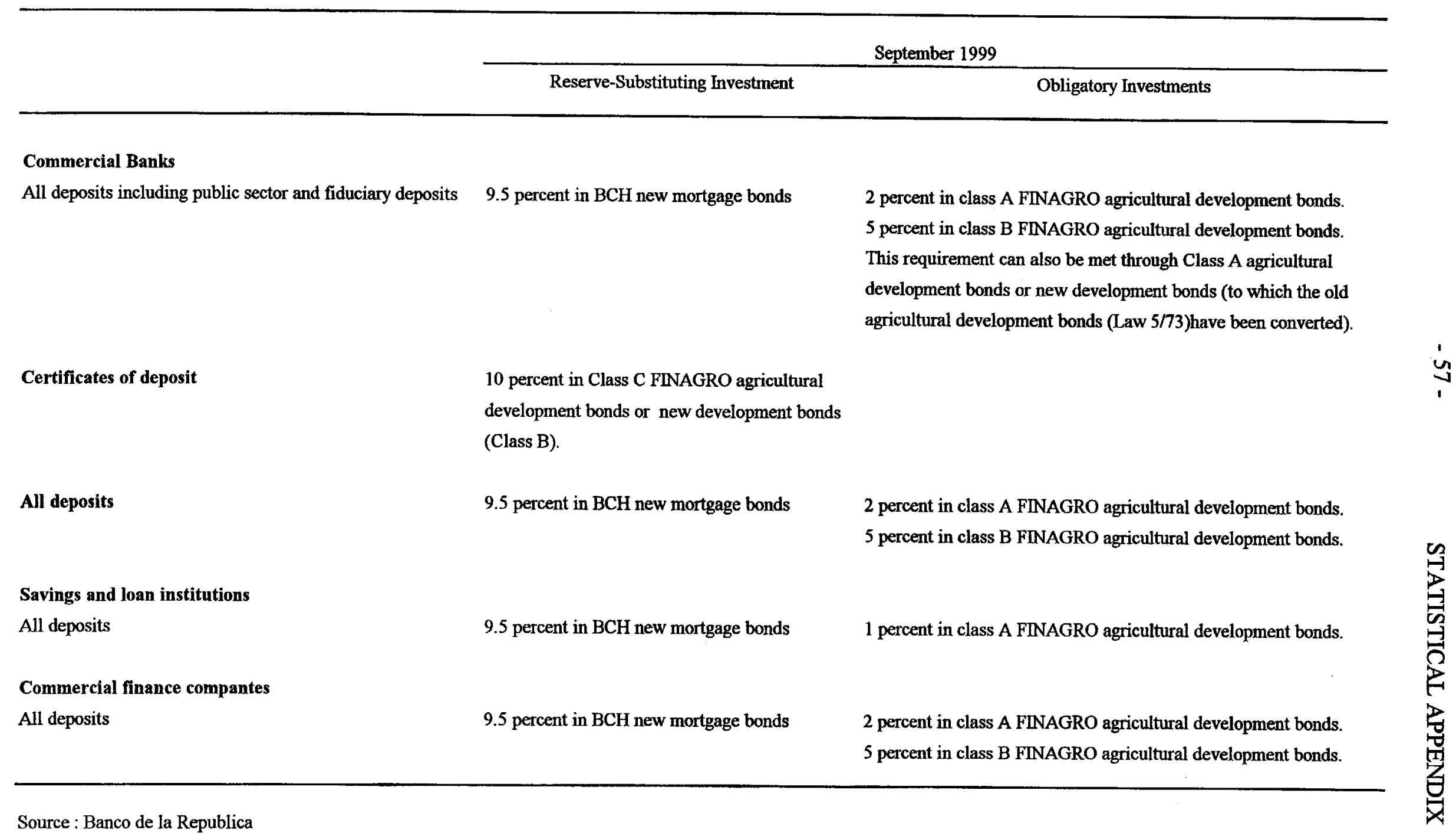


Table 42. Colombia: Net International Reserves of the Banco de la Republica (In billions of U.S. dollars)

\begin{tabular}{|c|c|c|c|c|c|c|}
\hline & 1994 & 1995 & 1996 & 1997 & 1998 & $\begin{array}{r}\text { Sep. } \\
1999\end{array}$ \\
\hline \multicolumn{7}{|c|}{ I. Stock at End of Period } \\
\hline Gross reserves & 8,103 & 8,453 & 9,938 & 9,908 & 8,741 & 8,009 \\
\hline Gold & 112 & 103 & 93 & 130 & 129 & 105 \\
\hline IMF position & 127 & 201 & 237 & 369 & 567 & 395 \\
\hline SDRs & 170 & 177 & 176 & 183 & 200 & 139 \\
\hline Foreign exchange & 7,454 & 7,721 & 9,183 & 8,950 & 7,305 & 6,330 \\
\hline Other & 241 & 251 & 249 & 276 & 540 & 1,040 \\
\hline Total liabilities & 8 & 7 & 6 & 3 & 1 & 127 \\
\hline Net international reserves & 8,095 & 8,446 & 9,932 & 9,905 & 8,740 & 7,882 \\
\hline \multicolumn{7}{|c|}{ II. Change During Year } \\
\hline Gross reserves & 171 & 350 & 1,485 & -30 & $-1,167$ & -732 \\
\hline Net international reserves & 180 & 351 & 1,486 & -27 & $-1,165$ & -858 \\
\hline Less: valuation adjustment & 0 & 0 & 0 & -91 & 161 & -109 \\
\hline \multirow[t]{2}{*}{$\begin{array}{l}\text { Change in net international } \\
\text { reserves adjusted for } \\
\text { valuation changes }\end{array}$} & & & & & & \\
\hline & 180 & 351 & 1,486 & 64 & $-1,326$ & -749 \\
\hline
\end{tabular}

Sources: Banco de la Republica. 
Table 43. Colombia: Merchandise Exports

\begin{tabular}{|c|c|c|c|c|c|c|c|c|}
\hline & \multirow{2}{*}{$\begin{array}{l}\text { Percent } \\
\text { of total } \\
\text { in } 1998\end{array}$} & \multirow[b]{2}{*}{1994} & \multirow[b]{2}{*}{1995} & \multirow[b]{2}{*}{1996} & \multirow[b]{2}{*}{1997} & \multirow[b]{2}{*}{1998} & \multicolumn{2}{|c|}{ Jan.Sep. } \\
\hline & & & & & & & 1998 & 1999 \\
\hline & \multicolumn{8}{|c|}{ (In millions of U.S. dollars, unless otherwise indicated) } \\
\hline Total exports & \multirow[t]{4}{*}{100.0} & 9,059 & 10,527 & 10,948 & 12,057 & 11,362 & 8,194 & 8,298 \\
\hline (percent change) & & 21.9 & 16.2 & 4.0 & 10.1 & -5.8 & -3.6 & 1.3 \\
\hline Volume, percent change $1 /$ & & 16.5 & 2.5 & -2.3 & 6.6 & 5.4 & $\ldots$ & $\ldots$ \\
\hline Unit value, percent change & & 4.7 & 13.4 & 6.5 & 3.3 & -10.6 & $\ldots$ & ... \\
\hline Coffee & \multirow[t]{4}{*}{16.6} & 1,990 & 1,832 & 1,577 & 2,259 & 1,891 & $\mathbf{0}$ & $\mathbf{0}$ \\
\hline (percent change) & & 74.6 & -8.0 & -13.9 & 43.3 & -16.3 & -0.1 & -0.3 \\
\hline Volume (million bags) & & 11.2 & 9.3 & 10.0 & 10.3 & 10.6 & $\ldots$ & $\ldots$ \\
\hline Unit value, f.o.b. (US\$/lb) & & 1.5 & 1.6 & 1.3 & 1.8 & 1.5 & $\ldots$ & ... \\
\hline Petroleum products & \multirow[t]{7}{*}{20.2} & 1,313 & 2,185 & 2,895 & 2,707 & 2,298 & 176 & 375 \\
\hline (percent change) & & -0.8 & 66.4 & 32.4 & -6.4 & -14.8 & $\mathbf{0}$ & 0.5 \\
\hline Crude oil & & 1,017 & 1,897 & 2,436 & 2,338 & 2,071 & 0 & 0 \\
\hline Volume $(1,000 \mathrm{bpd})$ & & 189.3 & 311.0 & 317.0 & 343.1 & 456.2 & $\ldots$ & $\ldots$ \\
\hline Unit value (US\$/bbl) & & 14.7 & 16.6 & 21.0 & 18.7 & 12.7 & $\ldots$ & $\ldots$ \\
\hline $\begin{array}{l}\text { Refined petroleum products } \\
\text { Of which }\end{array}$ & & 296 & 288 & 459 & 370 & 227 & 176 & 375 \\
\hline Fuel oil & & 215 & 220 & 288 & 255 & 162 & $\ldots$ & $\ldots$ \\
\hline Coal & \multirow[t]{4}{*}{8.2} & $\mathbf{5 5 0}$ & 596 & 849 & 886 & 934 & $\mathbf{0}$ & $\mathbf{0}$ \\
\hline (percent change) & & -2.5 & 7.7 & 42.5 & 4.3 & 5.4 & 12.8 & 3.3 \\
\hline Volume (million tons) & & 18.5 & 18.4 & 24.9 & 25.8 & 30.1 & $\ldots$ & $\ldots$ \\
\hline Unit value (US\$/ton) & & 29.8 & 32.4 & 34.1 & 34.3 & 31.0 & $\ldots$ & ... \\
\hline Nonmonetary gold & \multirow[t]{4}{*}{0.8} & 35 & 169 & 205 & 183 & 92 & $\mathbf{0}$ & $\mathbf{0}$ \\
\hline (percent change) & & -88.7 & 375.5 & 21.3 & -10.8 & -49.8 & 0.0 & 0.0 \\
\hline Volume $(1,000$ oz troy) & & 105.1 & 474.5 & 531.5 & 550.4 & 311.7 & $\ldots$ & $\ldots$ \\
\hline Price (US\$/oz) & & 384.1 & 384.1 & 387.7 & 331.1 & 294.2 & $\ldots$ & $\cdots$ \\
\hline Nickel & \multirow[t]{4}{*}{1.0} & 119 & 185 & 169 & 161 & 118 & 13 & 15 \\
\hline (percent change) & & 16.6 & 55.6 & -8.8 & -4.8 & -25.5 & 0.0 & 0.0 \\
\hline Volume (million lbs) & & 51.5 & 56.5 & 54.1 & 52.5 & 57.2 & $\ldots$ & $\ldots$ \\
\hline Price (US\$/1b) & & 2.3 & 3.3 & 3.1 & 3.1 & 2.1 & $\ldots$ & $\ldots$ \\
\hline Emerald & \multirow[t]{2}{*}{0.7} & 423 & 452 & 175 & 141 & 83 & $\mathbf{0}$ & $\mathbf{0}$ \\
\hline (percent change) & & 5.9 & 6.9 & -61.4 & -19.1 & -41.3 & 0.0 & 0.0 \\
\hline Nontraditional exports & \multirow{4}{*}{47.5} & 4,116 & 4,677 & 4,656 & 5,192 & 5,399 & $\mathbf{0}$ & $\mathbf{0}$ \\
\hline (percent change) & & 14.8 & 13.6 & -0.5 & 11.5 & 4.0 & 0.0 & 0.0 \\
\hline Volume, percent change & & 12.6 & 6.6 & 2.5 & 18.9 & 7.7 & $\cdots$ & ... \\
\hline Unit value, percent change & & 2.0 & 6.6 & -2.9 & -6.2 & -3.5 & $\ldots$ & $\cdots$ \\
\hline Agricultural products & 11.8 & 1,247 & 1,227 & 1,231 & 1,306 & 1,343 & 1,075 & 1,099 \\
\hline Manufactured goods & 35.2 & 2,803 & 3,401 & 3,349 & 3,835 & 3,994 & 3,082 & 2,812 \\
\hline Mining products & 0.5 & 67 & 49 & 76 & 51 & 62 & 43 & 88 \\
\hline \multirow{2}{*}{$\begin{array}{l}\text { Others } 2 / \\
\text { (percent change) }\end{array}$} & \multirow[t]{2}{*}{4.8} & 513 & 432 & 424 & 528 & 548 & $\cdots$ & $\ldots$ \\
\hline & & $\ldots$ & -15.7 & -1.8 & 24.5 & 3.8 & $\ldots$ & ... \\
\hline
\end{tabular}

Sources: DANE; Banco de la Republica; and Fund staff estimates.

1/ Excluding emerald.

2/ Special goods traded in the free-trade zone. 
Table 44. Colombia: Nontraditional Exports 1/

(In millions of U.S. dollars)

\begin{tabular}{|c|c|c|c|c|c|c|}
\hline & \multirow[b]{2}{*}{1995} & \multirow[b]{2}{*}{1996} & \multirow[b]{2}{*}{1997} & \multirow[b]{2}{*}{1998} & \multicolumn{2}{|c|}{ Jan.-Sep. } \\
\hline & & & & & 1998 & 1999 \\
\hline Total nontraditional exports & $4,677.2$ & $4,655.5$ & $5,192.4$ & $5,398.6$ & $4,200.0$ & $3,997.9$ \\
\hline Agriculture and fisheries & $1,226.9$ & $1,231.3$ & $1,306.2$ & $1,342.8$ & $1,075.0$ & $1,098.7$ \\
\hline Bananas & 431.0 & 459.5 & 502.7 & 476.1 & 342.3 & 682.0 \\
\hline Flowers & 475.8 & 509.5 & 544.6 & 556.7 & 443.3 & 121.0 \\
\hline Seafoods & 175.4 & 156.7 & 163.2 & 152.9 & 114.3 & 53.6 \\
\hline Cotton & 12.8 & 12.3 & 1.2 & 0.4 & 0.4 & 0.2 \\
\hline Meat & 3.1 & 1.8 & 1.8 & 6.3 & 4.3 & 0.8 \\
\hline Cocoa & 0.5 & 1.3 & 1.5 & 1.4 & 0.9 & 0.4 \\
\hline Tobacco & 13.4 & 19.4 & 19.4 & 16.2 & 14.7 & 8.8 \\
\hline Fruits and vegetables & 45.8 & 20.6 & 20.6 & 28.8 & 16.6 & 50.1 \\
\hline Rice & 0.2 & 0.0 & 0.0 & 0.2 & 0.1 & 0.0 \\
\hline Other agricultural products & 68.9 & 50.2 & 51.2 & 103.8 & 138.1 & 181.8 \\
\hline Industrial and manufacturing products & $\mathbf{3 , 4 0 1 . 4}$ & $3,348.7$ & $3,834.8$ & 3,993.9 & $3,082.0$ & $2,811.5$ \\
\hline Chemicals & 820.8 & 882.0 & $1,053.9$ & $1,086.6$ & 841.9 & 481.5 \\
\hline Garments & 621.9 & 530.5 & 506.5 & 491.1 & 362.3 & 21.0 \\
\hline Paper products & 254.6 & 222.9 & 251.0 & 272.8 & 204.4 & 124.4 \\
\hline Textiles & 220.7 & 219.8 & 217.6 & 186.4 & 145.1 & 21.0 \\
\hline Leather products (excluding footwear) & 161.6 & 97.4 & 129.0 & 135.1 & 99.4 & 14.4 \\
\hline Coffee extracts & 112.9 & 125.8 & 159.7 & 145.2 & 117.4 & 8.2 \\
\hline Machinery and equipment & 190.8 & 191.1 & 255.0 & 282.4 & 208.9 & 36.0 \\
\hline Metals and metal products & 170.0 & 167.3 & 207.4 & 225.1 & 165.1 & 180.3 \\
\hline Cement & 49.7 & 61.6 & 65.1 & 73.4 & 54.5 & 535.0 \\
\hline Plastics and rubber & 115.0 & 121.7 & 131.4 & 125.4 & 98.8 & 28.7 \\
\hline Sugar and molasses & 91.8 & 191.1 & 239.3 & 300.5 & 251.8 & 832.2 \\
\hline Footwear & 41.1 & 28.7 & 24.9 & 19.5 & 10.8 & 7.8 \\
\hline Wood products & 16.6 & 24.9 & 16.8 & 23.1 & 17.6 & 54.7 \\
\hline Glass & 16.4 & 14.7 & 17.1 & 15.3 & 8.8 & 6.4 \\
\hline Transportation equipment & 87.8 & 120.0 & 206.4 & 191.1 & 172.1 & 8.8 \\
\hline Other industrial products & 429.7 & 349.2 & 353.7 & 420.9 & 323.1 & 451.1 \\
\hline Mineral products & 48.9 & 75.5 & $\mathbf{5 1 . 4}$ & 61.9 & 43.0 & 87.7 \\
\hline Platinum & 15.0 & 9.1 & 2.7 & 2.9 & 2.5 & 0.0 \\
\hline Others & 33.9 & 66.4 & 48.7 & 59.0 & 40.5 & 87.7 \\
\hline \multicolumn{7}{|l|}{ Memorandum items: } \\
\hline Total merchandise exports $2 /$ & $10,095.3$ & $10,524.0$ & $11,529.3$ & $10,813.9$ & $8,193.9$ & $8,298.2$ \\
\hline $\begin{array}{l}\text { Nontraditional exports as a } \\
\text { percentage of total exports }\end{array}$ & 483 & $45 ?$ & 465 & 511 & & $48 ?$ \\
\hline & $90 . J$ & 43.2 & 40.5 & 51.1 & 31.3 & 48.2 \\
\hline
\end{tabular}

Source: National Department of Statistics (DANE).

1/ Traditional exports comprise coal, gold, coffee, petroleum products, nickel, and emerald.

2/ Excluding special goods traded in the free trade zone. 
Table 45. Colombia: Tax Credit Certificates for Exports

\begin{tabular}{|c|c|c|c|}
\hline & $\begin{array}{c}\text { Value of } \\
\text { Certificates } \\
\text { Issued }\end{array}$ & $\begin{array}{l}\text { Exchange } \\
\text { Surrenders } \\
\text { for Minor } \\
\text { Exports }\end{array}$ & $\begin{array}{r}\text { Tax Credit } \\
\text { Rate } 1 /\end{array}$ \\
\hline & \multicolumn{2}{|c|}{ (In millions of Colombian pesos) } & (In percent) \\
\hline 1994 & 65,877 & $2,784,799$ & 2.4 \\
\hline I & 10,730 & 763,472 & 1.4 \\
\hline II & 11,519 & 686,364 & 1.7 \\
\hline III & 23,668 & 658,858 & 3.6 \\
\hline IV & 19,960 & 676,105 & 3.0 \\
\hline 1995 & 78,724 & $3,126,462$ & 2.5 \\
\hline I & 19,311 & 732,010 & 2.6 \\
\hline II & 17,151 & 742,932 & 2.3 \\
\hline III & 20,427 & 777,057 & 2.6 \\
\hline IV & 21,835 & 874,463 & 2.5 \\
\hline 1996 & 86,620 & $3,023,261$ & 2.9 \\
\hline I & 22,805 & 786,776 & 2.9 \\
\hline II & 19,227 & 774,963 & 2.5 \\
\hline III & 17,236 & 729,699 & 2.4 \\
\hline IV & 27,352 & 731,823 & 3.7 \\
\hline 1997 & 71,217 & $3,416,767$ & 2.1 \\
\hline I & 23,853 & 723,404 & 3.3 \\
\hline II & 13,843 & 774,513 & 1.8 \\
\hline III & 7,062 & 909,577 & 0.8 \\
\hline IV & 26,459 & $1,009,273$ & 2.6 \\
\hline 1998 & 87,477 & $3,967,837$ & 2.2 \\
\hline I & 20,938 & 931,436 & 2.2 \\
\hline II & 29,620 & 992,050 & 3.0 \\
\hline III & 28,367 & $1,002,110$ & 2.8 \\
\hline IV & 8,552 & $1,042,242$ & 0.8 \\
\hline 1999 & 63,068 & $3,819,449$ & 1.7 \\
\hline I & 37,073 & 878,856 & 4.2 \\
\hline II & 25,995 & $2,940,593$ & 0.9 \\
\hline
\end{tabular}

Source: Banco de la Republica.

1/ Value of certificates issued in relation to value of exchange surrenders for minor exports. 
Table 46. Colombia: Exports by Country of Destination (In percent of total)

\begin{tabular}{|c|c|c|c|c|c|c|}
\hline & & & & & \multicolumn{2}{|c|}{ Jan.-Sep. } \\
\hline & 1995 & 1996 & 1997 & 1998 & $\overline{1998}$ & 1999 \\
\hline Total & 100.0 & 100.0 & 100.0 & 100.0 & 100.0 & 100.0 \\
\hline Western Hemisphere & 66.0 & 69.3 & 68.6 & 69.7 & 69.2 & 75.8 \\
\hline United States and Canada & 36.4 & 40.9 & 39.1 & 39.3 & 37.0 & 49.0 \\
\hline CACM and CARICOM & 2.4 & 3.2 & 3.1 & 3.0 & 3.0 & 3.0 \\
\hline $\begin{array}{l}\text { LAIA 1/ } \\
\text { Of which }\end{array}$ & 23.8 & 21.7 & 23.0 & 24.3 & 25.0 & 19.1 \\
\hline Andean Group & 19.7 & 17.4 & 18.4 & 19.8 & 20.5 & 14.4 \\
\hline Venezuela & 9.3 & 7.4 & 8.6 & 10.6 & 10.9 & 8.1 \\
\hline Ecuador & 4.1 & 4.0 & 4.7 & 5.3 & 5.4 & 2.9 \\
\hline Other & 6.3 & 6.0 & 5.1 & 3.9 & 4.2 & 3.4 \\
\hline Other & 3.3 & 3.5 & 3.5 & 3.1 & 4.2 & 4.7 \\
\hline Europe & 26.1 & 24.3 & 24.5 & 24.0 & 24.2 & 17.9 \\
\hline EU & 23.4 & 21.5 & 21.3 & 21.4 & 21.5 & 15.7 \\
\hline Bilateral payments agreements & 0.3 & 0.6 & 1.0 & 0.7 & 1.9 & 1.5 \\
\hline Other & 2.4 & 2.2 & 2.2 & 1.9 & 0.7 & 0.7 \\
\hline Asia & 6.4 & 4.9 & 5.1 & 4.3 & 4.6 & 4.0 \\
\hline Rest of the world & 1.6 & 1.5 & 1.8 & $\mathbf{2 . 0}$ & 2.1 & 2.4 \\
\hline
\end{tabular}

Source: National Department of Statistics (DANE).

1/ Latin American Integration Association. 
Table 47. Colombia: Imports by Economic Category (In millions of U.S. dollars)

\begin{tabular}{|c|c|c|c|c|c|c|}
\hline & \multirow[b]{2}{*}{1995} & \multirow[b]{2}{*}{1996} & \multirow[b]{2}{*}{1997} & \multirow[b]{2}{*}{1998} & \multicolumn{2}{|c|}{ Jan.-Jul. } \\
\hline & & & & & 1998 & 1999 \\
\hline Total imports, c.i.f. & 13,853 & 13,684 & 15,378 & 14,634 & 9,300 & 5,976 \\
\hline Consumer goods & 2,689 & 2,331 & 2,969 & 2,831 & 1,755 & 1,135 \\
\hline Durable & 1,451 & 995 & 1,297 & 1,138 & 767 & 325 \\
\hline Nondurable & 1,238 & 1,337 & 1,672 & 1,693 & 988 & 810 \\
\hline Intermediate goods & 6,128 & 6,159 & 6,575 & 6,224 & 3,951 & 2,742 \\
\hline Fuel, other petroleum products & 372 & 353 & 439 & 305 & 190 & 135 \\
\hline Agricultural inputs & 343 & 447 & 463 & 483 & 280 & 251 \\
\hline Industrial inputs & 5,413 & 5,359 & 5,673 & 5,437 & 3,481 & 2,356 \\
\hline Capital goods & 5,027 & 5,182 & $\mathbf{5 , 8 2 7}$ & 5,573 & $3, \mathbf{5 9 3}$ & 2,096 \\
\hline Construction industry & 261 & 421 & 391 & 347 & 206 & 91 \\
\hline Agriculture & 75 & 59 & 56 & 48 & 32 & 18 \\
\hline Manufacturing industry & 3,356 & 3,485 & 3,796 & 3,745 & 2,414 & 1,371 \\
\hline Transportation equipment & 1,335 & 1,217 & 1,585 & 1,433 & 941 & 617 \\
\hline Unidentified goods & 9.8 & 10.9 & 7.5 & 5.9 & 1.4 & 2.2 \\
\hline Cost, insurance, and freight & -932 & -890 & -969 & -908 & -574 & -356 \\
\hline Total imports, f.o.b. & 12,921 & 12,794 & 14,410 & 13,726 & $\mathbf{8 , 7 2 7}$ & 5,620 \\
\hline
\end{tabular}

Sources: Banco de la Republica; and National Department of Statistics (DANE). 
Table 48. Colombia: Imports by Country of Origin (In millions of U.S. dollars)

\begin{tabular}{|c|c|c|c|c|c|c|}
\hline & \multirow[b]{2}{*}{1995} & \multirow[b]{2}{*}{1996} & \multirow[b]{2}{*}{1997} & \multirow[b]{2}{*}{1998} & \multicolumn{2}{|c|}{ Jan.-Aug. } \\
\hline & & & & & $\overline{1998}$ & 1999 \\
\hline Total & 100.0 & 100.0 & 100.0 & 100.0 & 100.0 & 100.0 \\
\hline Western Hemisphere & 67.2 & 68.9 & 70.4 & 66.4 & 66.4 & 70.4 \\
\hline United States and Canada & 41.7 & 43.6 & 43.9 & 40.8 & 40.6 & 43.5 \\
\hline CACM and CARICOM & 0.4 & 0.3 & 0.3 & 0.4 & 0.3 & 0.4 \\
\hline LAIA 1/ & 22.3 & 22.5 & 23.1 & 22.4 & 22.5 & 22.6 \\
\hline Of which & & & & & & \\
\hline Andean Group & 13.2 & 13.1 & 13.9 & 13.0 & 13.1 & 11.9 \\
\hline Venezuela & 9.8 & 9.2 & 10.0 & 9.3 & 9.6 & 7.9 \\
\hline Ecuador & 2.0 & 2.4 & 2.6 & 2.2 & 2.1 & 2.5 \\
\hline Other & 1.4 & 1.4 & 1.4 & 1.6 & 1.4 & 1.5 \\
\hline Other & 2.7 & 2.5 & 3.0 & 2.8 & 3.0 & 3.9 \\
\hline Europe & 20.7 & 21.4 & 20.1 & 22.6 & 22.7 & 20.1 \\
\hline EU & 16.4 & 17.4 & 15.7 & 17.9 & 18.0 & 16.6 \\
\hline Bilateral payments agreements & 0.3 & 0.2 & 0.4 & 0.4 & 4.2 & 3.4 \\
\hline Other & 4.0 & 3.9 & 4.0 & 4.3 & 0.5 & 0.1 \\
\hline Asia & 11.3 & 8.8 & 8.5 & 9.6 & 9.5 & 8.2 \\
\hline Rest of the world & 0.8 & 0.9 & 1.1 & 1.3 & 1.3 & 1.3 \\
\hline
\end{tabular}

Source: National Department of Statistics (DANE).

1/ Latin American Integration Association. 
Table 49. Colombia: Tariff Rate Indicators

(In percent)

\begin{tabular}{|c|c|c|c|c|c|c|}
\hline & \multirow[b]{2}{*}{1995} & \multirow[b]{2}{*}{1996} & \multirow[b]{2}{*}{1997} & \multirow[b]{2}{*}{1998} & \multicolumn{2}{|c|}{ Jan.-Aug. } \\
\hline & & & & & 1998 & 1999 \\
\hline $\begin{array}{l}\text { Average effective } \\
\text { tariff protection }\end{array}$ & 19.8 & 19.1 & 19.7 & 19.7 & 19.7 & 19.7 \\
\hline Consumer goods & 34.4 & 34.3 & 34.9 & 36.0 & 36.0 & 36.0 \\
\hline Intermediate goods & 15.0 & 14.8 & 15.5 & 15.3 & 15.3 & 15.3 \\
\hline Capital goods & 12.8 & 13.3 & 13.0 & 13.3 & 13.3 & 13.3 \\
\hline $\begin{array}{l}\text { Average nominal tariff } \\
\text { protection }\end{array}$ & 11.5 & 11.6 & 11.6 & 11.6 & 11.6 & 11.6 \\
\hline Standard deviation & & & & & & \\
\hline Excluding import surcharge & 6.5 & 6.4 & 6.4 & 6.4 & 6.4 & 6.4 \\
\hline Including import surcharge & 6.5 & 6.4 & 6.4 & 6.4 & 6.4 & 6.4 \\
\hline Number of tariff categories $1 /$ & 3 & 4 & 4 & 4 & 4 & 4 \\
\hline
\end{tabular}

Source: National Planning Department.

1/ Excludes automobiles and agricultural products. 
Table 50. Colombia: External Public Loans 1/

\begin{tabular}{|c|c|c|c|c|c|c|c|c|c|c|c|c|c|c|c|}
\hline & \multicolumn{5}{|c|}{ In Millions of U.S. Dollars } & \multicolumn{5}{|c|}{$\begin{array}{l}\text { Average Interest Rate } 2 / \\
\text { (Percent per annum) }\end{array}$} & \multicolumn{5}{|c|}{ Average Maturity in Years } \\
\hline & 1994 & 1995 & 1996 & 1997 & 1998 & 1994 & 1995 & 1996 & 1997 & 1998 & 1994 & 1995 & 1996 & 1997 & 1998 \\
\hline All loans & 1,715 & 1,715 & 3,489 & 2,331 & 3,104 & 7.3 & 6.8 & 8.0 & 8.0 & 8.2 & 10.9 & 9.1 & 8.5 & 10.6 & 7.1 \\
\hline \multicolumn{16}{|l|}{ By sector } \\
\hline Communications & 82 & 49 & 18 & 0 & 0 & 5.2 & 5.9 & 7.2 & $\ldots$ & 8.0 & 9.1 & 12.9 & 7.9 & $\ldots$ & 4.5 \\
\hline Power & 607 & 171 & 1,057 & 232 & 30 & 7.1 & 7.0 & 7.6 & 8.2 & 7.0 & 13.3 & 6.7 & 7.5 & 6.7 & 7.3 \\
\hline Industry & 0 & 105 & 125 & 0 & 0 & $\ldots$ & 9.1 & 8.4 & $\ldots$ & $\cdots$ & $\ldots$ & 3.6 & 5.0 & $\cdots$ & $\cdots$ \\
\hline Transportation & 177 & 2 & 101 & 0 & 31 & 6.0 & 7.8 & 7.8 & $\cdots$ & 6.7 & 11.5 & 5.0 & 9.9 & $\ldots$ & 9.5 \\
\hline Water and sewerage & 0 & 0 & 0 & 0 & 49 & $\cdots$ & $\ldots$ & $\ldots$ & $\ldots$ & 7.4 & $\ldots$ & $\ldots$ & $\ldots$ & $\ldots$ & 15.3 \\
\hline Other 3/ & 849 & 1,387 & 2,188 & 2,099 & 2,993 & 7.6 & 6.7 & 8.2 & 7.9 & 8.3 & 9.3 & 9.7 & 9.2 & 9.2 & 6.9 \\
\hline \multicolumn{16}{|l|}{ By borrower } \\
\hline $\begin{array}{l}\text { Central government } \\
\text { Departments and }\end{array}$ & 824 & 1,145 & 1,711 & 1,612 & 2,839 & 7.6 & 6.4 & 8.4 & 8.1 & 8.3 & 9.4 & 9.9 & 9.9 & 12.6 & 6.6 \\
\hline municipalities & 861 & 224 & 402 & 509 & 79 & 6.6 & 7.7 & 7.5 & 7.5 & 6.4 & 12.5 & 11.4 & 4.1 & 5.5 & 15.1 \\
\hline Rest of public sector $4 /$ & 30 & 345 & 1,376 & 210 & 186 & 9.3 & 7.6 & 7.7 & 7.9 & 7.1 & 7.5 & 5.1 & 8.1 & 8.0 & 11.6 \\
\hline Banco de la Republica & 0 & 0 & 0 & 0 & 0 & $\cdots$ & $\cdots$ & $\cdots$ & $\cdots$ & $\ldots$ & $\ldots$ & $\cdots$ & $\cdots$ & $\cdots$ & $\cdots$ \\
\hline
\end{tabular}

Source: Banco de la Republica.

1/ On a commitment basis

2/ Interest rates for loans based on LIBOR were estimated as the sum of individual interest spreads plus the average daily rate on six-month deposits in the year the loan was contracted.

$3 /$ Includes general purpose loans.

4/ Includes publicly guaranteed loans 
Table 51. Colombia: External Debt and Debt-Service

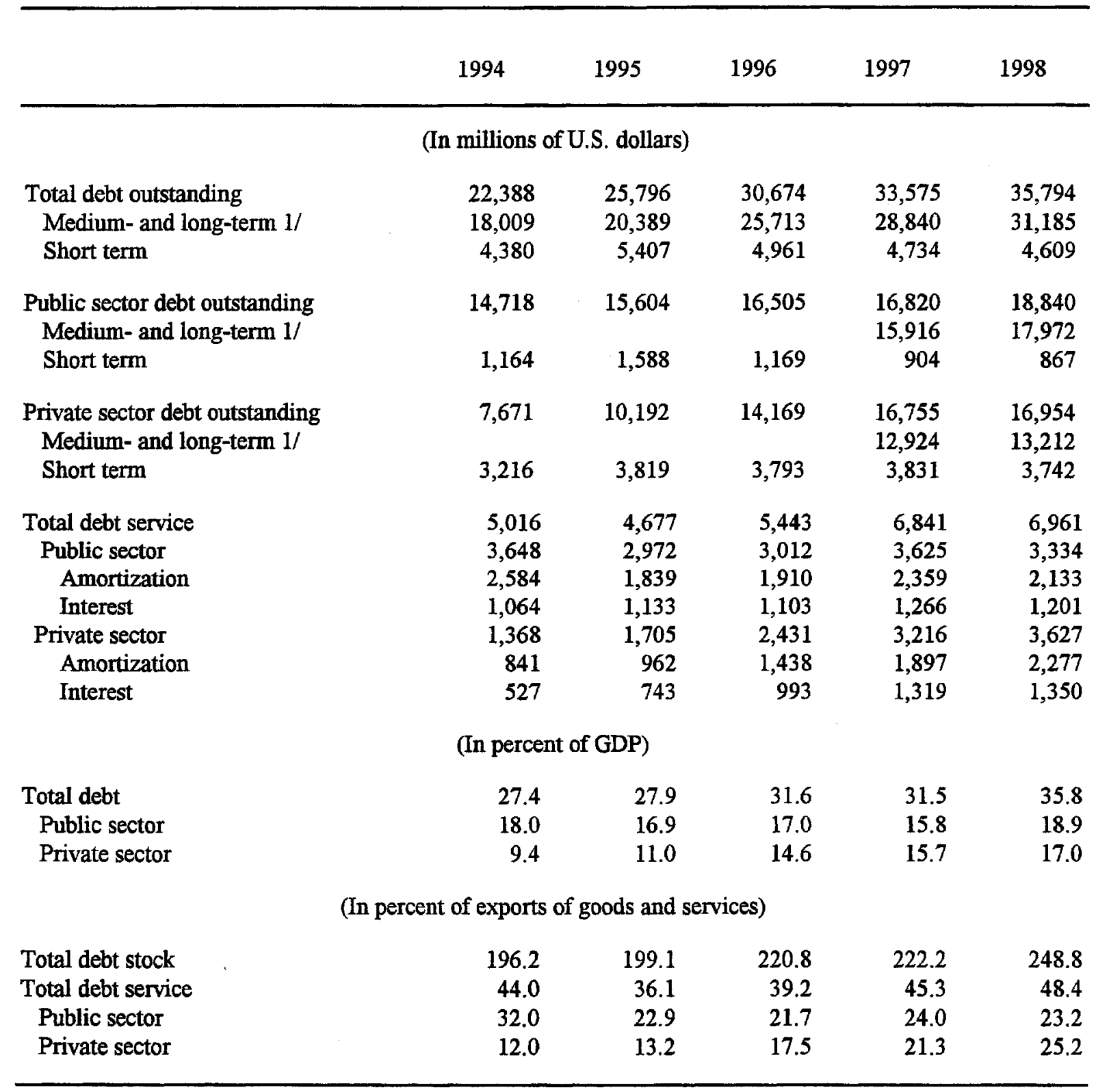

Sources: Banco de la Republica; and Fund staff projections.

1/ Includes leasing. 
Table 52. Colombia: Public Sector External Debt by Creditor 1/

\begin{tabular}{|c|c|c|c|c|c|c|}
\hline & 1995 & 1996 & 1997 & $\begin{array}{l}\text { Prel. } \\
1998\end{array}$ & $\begin{array}{r}\text { Jan.-Jun. } \\
1998\end{array}$ & $\begin{array}{r}\text { Jan.-Jun. } \\
1999\end{array}$ \\
\hline \multicolumn{7}{|c|}{ (In millions of U.S. dollars; end of period) } \\
\hline Public sector debt & 13,952 & 15,082 & 15,519 & 17,493 & 16,548 & 18,143 \\
\hline Bilateral & 1,747 & 1,738 & 1,591 & 1,527 & 1,507 & 1,372 \\
\hline Multilateral organizations & 5,649 & 5,053 & 4,447 & 4,963 & 4,561 & 5,317 \\
\hline IBRD & 2,548 & 2,174 & 1,718 & 1,744 & 1,646 & 1,722 \\
\hline IDB & 2,920 & 2,722 & 2,475 & 2,777 & 2,477 & 2,948 \\
\hline Other & 181 & 157 & 255 & 442 & 438 & 667 \\
\hline Commercial banks & 4,307 & 4,429 & 4,613 & 4,656 & 4,694 & 4,460 \\
\hline Bonds & 1,733 & 3,410 & 4,441 & 5,880 & 5,357 & 6,581 \\
\hline Other (suppliers) & 516 & 451 & 427 & 468 & 429 & 413 \\
\hline \multicolumn{7}{|c|}{ (In percent of total) } \\
\hline Bilateral & 12.5 & 11.5 & 10.2 & 8.7 & 9.1 & 7.6 \\
\hline Multilateral organizations & 40.5 & 33.5 & 28.7 & 28.4 & 27.6 & 29.3 \\
\hline IBRD & 18.3 & 14.4 & 11.1 & 10.0 & 9.9 & 9.5 \\
\hline IDB & 20.9 & 18.0 & 15.9 & 15.9 & 15.0 & 16.2 \\
\hline Other & 1.3 & 1.0 & 1.6 & 2.5 & 2.6 & 3.7 \\
\hline Commercial banks & 30.9 & 29.4 & 29.7 & 26.6 & 28.4 & 24.6 \\
\hline Bonds & 12.4 & 22.6 & 28.6 & 33.6 & 32.4 & 36.3 \\
\hline Other (suppliers) & 3.7 & 3.0 & 2.8 & 2.7 & 2.6 & 2.3 \\
\hline
\end{tabular}

Source: Banco de la Republica.

1/ Does not include short-term public debt or publicly guaranteed private debt. 